\title{
Beyond the New Deal: Coal and the Clean Air Act*
}

\author{
Bruce A. Ackerman ${ }^{\dagger}$ and William T. Hassler $\ddagger$
}

\section{TABLE OF CONTENTS}

I. Beyond the New Deal Agency 1471

A. The New Deal Ideal 1471

B. A New Generation Confronts the New Deal 1474

C. From Statute to Policy 1479

1. Technology in a Vacuum 1479

2. Squaring the Circle 1483

II. The Politics of Ignorance 1487

A. Setting the Agenda 1488

1. The Navajo Challenge: The Distorting Prism of Adjudication

2. The Struggle over Existing Plants

* Copyright (C) 1980 by Bruce A. Ackerman and William T. Hassler. Work on this essay began in May 1979, when Hassler accompanied Ackerman during the latter's two-week stay as Visiting Professor with the General Counsel's Office of the Environmental Protection Agency (EPA) in Washington, D.C. This was a time of intensive interviewing with actors both in and out of government as well as a preliminary canvass of the EPA docket. Summer and fall were spent studying the docket and supplementing the initial set of interviews. We are especially grateful to the more than fifty people who, under pledge of confidentiality, spoke with us. Pursuant to our commitments to them, we have not attributed particular findings to particular interviewees. Nonetheless, we could not have written the article without them.

During the past year, our work has been supported by grants from the Kaiser and Commonwealth Foundations to Yale's Institution for Social and Policy Studies (ISPS). We especially appreciate the moral support received from the participants in the ISPS faculty seminar on health policy led by Ted Marmor. A fuller version of this essay will be published by Yale University Press under the title Dirty AIR/Clean Cont.

Of course, none of the institutions mentioned in this footnote are responsible for the errors that remain in this essay.

+ Professor of Law, Yale University.

\pm J.D., Yale Law School, 1980. During the summer of 1978 , following his first year in law school, Mr. Hassler served as a summer clerk for the firm of Hunton \& Williams, which is representing a group of utility companies in the present NSPS litigation. At no time, however, did Mr. Hassler work in the firm's environmental section or participate in the NSPS litigation in any way; nor did he return to the firm during his second summer. As a consequence, his association with the firm had ended before his project with Professor Ackerman began. In addition, during the following summer, Mr. Hassler was a clerk with a second law firm and participated in that firm's effort to assist the Natural Resources Defense Council (NRDC) in an environmental matter unrelated to NRDC's participation in the controversies discussed in the present article. Upon graduation, MIr. Hassler has not renewed his professional association with either Hunton \& Williams or NRDC, and has obtained other employment. 
B. The Clean Air-Dirty Coal Coalition 1492

1. The Clean Air Regions 1493

2. The House Proposals of 1976

3. The Uses of Technocratic Intelligence 1495

4. Dirty Coal and Clean Air Converge 1497

5. Avoiding Debate: $1976 \quad 1501$

C. Midnight Lawmaking: The Problem of Agenda Overload 1502

1. Energy Policy Takes Center Stage 1502

2. Regional Protectionism in the Open 1504

3. The Conference Compromise: Fabricating Legislative History

D. Beyond the New Deal: Congressional Performance 1511

III. To What End? 1514

A. Defining the Problem: Sulfur Oxides 1515

B. Protecting Health and Environment in the East: The
Perils of Scrubbing

1. Short-Term Action 1522

2. Long-Term Responsibilities 1528

C. Beyond the East: The Problem of Visibility 1532

IV. Expertise in the Service of Politics 1536

A. EPA at War with Itself 1536

B. Executive Intervention 1542

C. Technocratic Ascendancy 1543

1. The Rise of Partial Scrubbing 1543

2. The View from the Center 1545

D. Agency Decision 1547

1. The High Tide of Instrumental Rationality 1548

2. Political Counterattack 1550

V. Agency-Forcing Statutes and the Role of Courts 1556
A. The Principle of Full Inquiry
1556
B. The Principle of Textual Priority 1559
C. The Coordination Principle 1561
D. Beyond Formalistic Review 1563

VI. Ends and Means in Administrative Law 1566 
Earth Day has passed, but its passions have marked our law in deep and abiding ways. Statutes passed in the early 1970s did more than commit hundreds of billions of dollars to the cause of environmental protection in the decades ahead. ${ }^{1}$ They also represent part of a complex effort by which the present generation is revising the system of administrative law inherited from the New Deal. The rise of environmental consciousness in the late 1960s coincided with the decline of an older dream-the image of an independent and expert administrative agency creatively regulating a complex social problem in the public interest. When Congress reacted to Earth Day, it set about to do more than clean the water and purify the air; it also sought a new shape for the administrative process-one that would avoid the use of "expertise" as an excuse for inaction and that would protect agencies from capture by special interests. It is a decade now since Congress began to articulate this new vision of administrative law-long enough for us to begin to test its aspirations against concrete results. In this spirit, we propose to sift a decade's experience generated by one of the countless experiments in administrative lawmaking written into the Clean Air Amendments of $1970 .{ }^{2}$ We seek to understand how decisionmakers perceived, defined, and solved problems in the evolving framework of environmental regulation, so that we may begin to distinguish experiments in administrative design that have succeeded from those that have failed.

Beyond this, our study also focuses upon a crucial substantive policy issue: the future of the coal-burning power plant. At present, such plants contribute forty-eight percent of all electric power produced in the United States. ${ }^{3}$ This share will grow over the next half century. ${ }^{1}$ With oil scarce, nuclear risky, solar embryonic, and hydro limited, the nation's rich and cheap coal reserves call for exploitation. ${ }^{5}$ At the same

1. The total annual cost of air and water pollution abatement in 1978 alone was \$39.5 billion, 10 U.S. Council on ENvironmental Quality, ANN. REP.: ENvironmental QuALITY-1979 at 667 (1979). The CEQ estimates that air and water pollution control costs will amount to $\$ 588$ billion between 1970 and 1987. Id.

2. Pub. L. No. 91-604, 84 Stat. 1676 (codified at 42 U.S.C. $\$ \$ 1857 \mathrm{~b}-1857 l$ (1976)) (amended 1977). The original Clean Air Act, Pub. L. No. 84-157, 69 Stat. 314 (1955), has been amended numerous times since its initial passage. The term "Act" will be used in text and notes to refer to the version of the Clean Air Act that is contextually relevant at that point in the essay.

3. 2 U.S. ENergy Information AdMin., ANn. ReP. to Congress 135 (1979) (1979 figures).

4. Coal-Bridge to the Future: Report of the World CoAl Study 245 (C. Wilson ed. 1980).

5. See id. at 61-83 (global prospects); $c f$. EnERgy Future: RePort of the Energy Project AT the Harvard Business School (R. Stobaugh \& D. Yergin eds. 1979). The Stobaugh and Yergin report strongly advocates increased use of alternative energy sources, such as solar energy. Id. at 216-33 (favoring "balanced" energy program). Nevertheless, it predicts a large and increasing role for the use of coal. Id. at 232-33. For a balanced critique of the Stobaugh and Yergin study that gives even greater emphasis to coal, see Joskow, America's many energy futures-a review of Energy Future, Energy: The Next Twenty Years, and Energy in America's Future, 11 BeLl J. ECoN. 377, 383-84 (1980). 
time, coal burning generates its own environmental costs. Coal-fired power plants are major sources of several pollutants; currently they are the single most important source of sulfur oxides. ${ }^{\circ}$ As a result, the control of new coalburners has gradually emerged as one of the most pressing questions confronting the Environmental Protection Agency (EPA), leading it, in June of 1979, to revise the "new source performance standards" (NSPS) it would impose upon sulfur emissions from new coal-burning power plants. ${ }^{7}$ Environmentalists and the utility industry have challenged the new NSPS in litigation currently before the United States Court of Appeals for the District of Columbia Circuit. ${ }^{8}$

A careful analysis of the EPA's decision will reveal the way our institutions are resolving a critical environmental trade-off generated by the energy crisis. We have concluded that Congress' well-intentioned effort in 1970 to improve environmental quality through an improved administrative process has led, in 1979 , to an extraordinary agency decision that will cost the public tens of billions of dollars to achieve environmental goals that could be reached more cheaply, more quickly, and more surely by other means. Indeed, the agency action is so inept that some of the nation's most populous areas will enjoy a worse environment than would have resulted if the new policy had never been put into effect.9 Yet the people who shaped the 1979 decision are remarkable for their high intelligence and conscientiousness. Their failure to make sensible policy is a symptom of organizational, not personal, breakdown-a failure to give decisionmakers bureaucratic incentives to ask the hard questions raised by any serious effort to control the environment. Thus, to understand the decision, we must do more than outline the substance of the environmental problem and the administrative response. We must address broader questions raised by the framework in which Congress, agencies, courts, and special interest groups interacted to form and implement policy.

Our story begins with the way Congress set about regulating the

6. In 1976, power plants produced $65 \%$ of the sulfur oxides, $29 \%$ of the nitrogen oxides, and $25 \%$ of the particulates emitted in the United States. EPA, 1976 NarionaL Emissions Rerort vii (1979) (EPA Pub. No. 450/4-79-019).

7. 44 Fed. Reg. 33,580-624 (1979) (codified in 40 C.F.R. $\$ 60.43 \mathrm{a}$ (1979)). The controversy surrounding the 1979 NSPS has already generated a modest literature. See, e.g., Energy: The Next Twenty Years 378-81 (Ford Foundation 1979); Navarro, The Politics of Air Pollution, PUB. INTERest, Spring 1980, at 36; Badger, New Source Standard for Power Plants I: Consider the Costs, 3 Harv. EnvT'L L. REv. 48 (1980); Ayres \& Doniger, New Source Standard for Power Plants II: Consider the Law, 3 HARv. ENvT'L L. REv. 63 (1980). Although we agree with many points made by Navarro, Badger, and the Ford group, none of these studies attempts a comprehensive analysis of the decision's merit or an institutional analysis of the decision's decade-long development.

8. Sierra Club v. Costle, No. 79-1565 (D.C. Cir., filed June 11, 1979).

9. See pp. 1515-36 infra. 
environment in 1970. Rather than consigning new power plants to the discretion of an independent expert agency idealized by New Deal theory, Congress tried to play a more aggressive role in policymaking. There are many different ways, however, that Congress could have tried to direct agency policy; indeed, it will be a principal purpose of this case study to isolate the agency-forcing statute as a legal form worthy of careful study in its own right. In its eagerness to move beyond New Deal ideals, the Congress of 1970 hit upon a form of agency forcing that replaces familiar New Deal maladies with new, but hardly less serious, diseases. The EPA responded to Congress' primitive effort at agency forcing by creating a regulatory universe only tangentially related to environmental realities. It treated the power plant problem as if it were an engineering exercise insulated from critical ecological and economic issues.

After setting the bureaucratic stage, we trace the way the coalburner rose to the surface of congressional deliberations in 1976 and 1977 , when the legislature was obliged to confront the consequences of its earlier exercises in aggressive policymaking. We then compare this post-New Deal process of congressional amendment with a viewpoint commended by New Deal ideals-one that focuses on the relationship between economic costs and ecological benefits promised by alternative regulatory policies. Having contrasted the competing decisionmaking perspectives, we can begin to appreciate the perplexities the EPA confronted in 1977-when it attempted to place its expertise at the service of a new congressional exercise in agency forcing enacted as part of the Clean Air Act Amendments of 1977. At this point, the conflict between administrative philosophies took institutional form, as different parts of the executive bureaucracy reacted differently to the congressional effort to move beyond the New Deal. It is only in the light of this bureaucratic struggle that the EPA Administrator's 1979 decision becomes more understandable, if not more rational.

Our study concludes by exploring the larger implications of the EPA's decision for the future of administrative law. We try to identify an appropriate role for courts that are called upon to resolve the perplexities generated by agency forcing. We then shift focus from judicial review to legislative reform. Congress was not wrong in hoping to move beyond New Deal ideals in 1970; it is imperative, however, that its early efforts in agency forcing be replaced by statutory structures that promise a more fruitful dialogue between politicians and technocrats in the decade ahead. 


\section{Beyond the New Deal Agency}

Imagine that Earth Day had fallen a generation earlier-when Franklin Roosevelt, rather than Richard Nixon, was in the White House. In response to a sense of crisis, the President asserts that the environment deserves a New Deal and turns to his Brain Trust for a legislative remedy. How would the New Deal have sought to transform the environmental impulse into a legal reality?

\section{A. The New Deal Ideal}

We shall isolate three distinct, if interrelated, elements of the New Deal answer. ${ }^{10}$ The first is the affirmation of expertise..$^{11}$ Understanding the environment, after all, is an exceedingly technical business requiring the coordination of a bewildering variety of specialties ranging from ecology to engineering to economics. The central task is to create a structure capable of deploying the varieties of relevant expert knowledge. Without a deep understanding of the scientific and social facts, there can be no hope of defining an intelligent solution to the chronic problems of a complex and interdependent society. In affirming the need for expertise, however, we should not be blind to the failures of particular experts. Most important is the problem of obsolescencescience marches on, new facts emerge, new theories evolve. Although an administrative agency may not be at the frontier of research, at the very least it should keep up with the consensus of informed opinion. This means that the ideal agency may, from time to time, be required to change course dramatically to take into account new insights generated by the best available knowledge. Such flexibility is absolutely essential if the agency is to free itself from ideas that no longer illuminate the changing reality it seeks to regulate.

Two institutional corollaries follow from the affirmation of expertise. The first is agency insulation from central political control. ${ }^{12}$ At the very best, detailed congressional instruction would freeze existing expert consensus into black letter law, thereby making it harder to cope

10. Although these principles have deep roots in American history, see M. BERnstern, Regulating Business BY InDEPEndent Commission 26-30, 37-39, 50-52 (1955), we follow the most thoughtful recent scholarship in viewing the New Deal as the period in which these ideals gained the most practical importance and intellectual support. See J. FrEEDMAN, Crisis AND Legrtimacy 32-33, 44-46, 59-60 (1978) (conception of New Deal ideal broadly consistent with model described in this article); Stewart, The Reformation of American Administrative Law, 88 Harv. L. Rev. 1667, 1676-81 (1975) (same); cf. J. LANds, The Administrative Process 23-24, 68-70 (1938) (contemporary account of New Deal ideals).

11. See J. FreEdMAN, supta note 10 , at $44-46$.

12. See id. at 59-62. 
with the problem of obsolescence. Moreover, there is little reason to expect the very best. In the words of James Landis, the most thoughtful New Deal theorist, " $[t]$ hose with experience in legislative matters . . . recognize that it is easier to plot a way through a labyrinth of detail when it is done in the comparative quiet of a[n agency] conference room than when it is attempted amid the turmoil of a legislative chamber or committee room."13 Rather than tying the agency's hands with a host of particular rules and detailed instructions, Congress should content itself with the most general kinds of policy guidance.

By restricting itself to the role of Polonius, Congress gives evidence of a self-conscious awareness of its institutional incompetence. Instead of imposing a hard and fast solution on a complex and changing problem, the legislature should instead invite the agency to organize the expert knowledge required for intelligent regulation. To implement this goal, Congress should try to insulate the agency from other sources of power that might overwhelm its deepening understanding of the policy problem. By making the agency "independent" from the executive, ${ }^{14}$ and by endowing it with multiple commissioners, ${ }^{15}$ the New Deal makes it difficult for a momentary national impulse to place its mark on the course of agency policy. An even more extreme form of insulation is provided by "cooperative federalism." Here, the states, operating under loose federal supervision, are asked to design a program responsive to the peculiarities of local conditions. ${ }^{16}$

13. J. LANDIs, supra note 10 , at 69-70.

14. We use the term "independent agency" to include those agencies whose heads the President cannot remove without cause. See K. Davis, Administrative Law and Government 16 (2d ed. 1975). Prominent independent agencies include the Interstate Commerce Commission (founded in 1887), the Federal Trade Commission (1914), the Federal Communications Commission (1934), the Securities and Exchange Commission (1934), and the Civil Aeronautics Board (1938). Id.

15. See id. at 17.

16. Although the states have often been celebrated as "laboratories" of innovation and experiment, there is a pervasive ambiguity concerning the kind of local conditions to which they are expected to respond. On the one hand, the states may be viewed as political bodies that ought to be responsive to local values and constituencies slighted in national politics. On the other hand, the states may be viewed merely as convenient repositories for expert bureaucracies with superior sensitivity to local contexts. Although both these views support insulation from the vagaries of national politics, they diverge in their affirmative recommendations. For a sensitive treatment of the tension, see Stewart, Pyramids of Sacrifice? Problems of Federalism in Mandating State Implementation of National Policy, 86 Yale L.J. 1196, 1211-22 (1977); for a sensitive legally-oriented study of the tensions generated by "cooperative" structures, see Mashaw, The Legal Structure of Frustration: Alternative Strategies for Public Choice Concerning Federally Aided Highway Construction, 122 U. PA. L. REV. 1 (1973); for critical views from other disciplines, see J. Pressman \& A. Wildavsky, Implementation 87-124 (1973); Rose-Ackerman, Risktaking and Reelection: Does Federalism Promote Innovation? 9 J. LEGAL STUD. (forthcoming June 1980). 
Not that insulation is ever conceived as complete. Through the power over agency appointments and appropriations, sustained shifts in national values are expressed over time. Agency policymaking, however, is not to be subordinated to every blip in national opinion; the agency is, first and foremost, to be responsive to the evolving complexity of the substantive problem it confronts.

But the New Deal agency is not only to be insulated from national politics; it is also to be insulated from judicial oversight. The overriding aim of administrative law is to discourage the courts from displacing expert policy judgments by their own legalistic readings of the statute. ${ }^{17}$ Thus, judicial review focuses on questions that promise to support the use of expertise-most notably, did the agency give serious consideration to all the relevant data and arguments? ${ }^{18}$ Beyond this, the courts are to restrain the temptation to second-guess agency decisions, striking down only those rare cases of arbitrary or capricious action that patently belied the myth of expertise. ${ }^{19}$

If Earth Day had fallen in the late thirties, then, one might imagine the Brain Trust advancing a familiar congressional remedy to a new social dis-ease. Congress should create an "independent" agency consisting of five commissioners-no more than three from the same party-to take on the enormous regulatory task. After sagely instructing the commissioners to preserve the integrity of nature, the health of the citizenry, and the prosperity of the economy, the statute should leave the commission on its own as it seeks to define a sound environmental policy. Rather than giving concrete policy guidance, the statute should diffuse political direction yet further by delegating vast areas of policymaking to the states.

Legalism should be kept to the periphery. Doubtless, there must be some guarantee that interested parties can obtain a hearing before the commissioners impose cleanup burdens upon them. Doubtless, industry will try to tie the commission's hands by making these hearings as long and complicated-and as court-like-as possible. Yet the courts

17. See FCC v. Pottsville Broadcasting Co., 309 U.S. 134, 138-44 (1940) (Frankfurter, J.); J. FreEDMAN, supra note 10, at $45-46$.

18. 2 K. Davis, Administrative Law Treatise $\$ 16.05$ (1st ed. 1958) (requirement that agency state findings and reasons); 4 id. $\$ \S 29.02,29.03$ ("substantial evidence" review on record as a whole).

19. See S. Breyer \& R. Stewart, Administrative Law and Regulatory Policy 288-90 (1979). A single paragraph cannot, of course, do justice to the complexity of the thought of scholars and judges who gave substance to this conception of administrative law, or to the countervailing tendencies that hid beneath its surface. Reading a few hundred pages, selected at random, from one of the great treatises of the last generation is the best way to gain a sense of the texture of the discourse. See K. Davis, supra note 18; L. JAFFE, Judicial Control of Administrative Action (1965). 
should support the expert agency's effort to resist these tendenciesgiving affected parties their constitutional due without depriving the agency of policymaking flexibility. ${ }^{20}$

\section{B. A New Generation Confronts the New Deal}

But Earth Day did not fall during the Great Depression. By the late sixties, a generation's experience had eroded New Deal confidence in expert policymaking. ${ }^{21}$ Two themes may be detected in the emerging chorus of criticism. The first, more conservative, line of attack did not directly assault the New Deal affirmation of expertise. Instead, it asserted that the agencies had somehow failed to make use of their broad rulemaking powers to engage in creative policymaking in the public interest. They had relapsed instead into the old lawyer-ridden ways of case-by-case adjudication, laboring mightily through procedural labyrinths without successfully defining basic directions for future regulation. ${ }^{22}$ Rather than becoming a home for dedicated experts, the independent commission seemed a revolving door for lawyers hoping to gain inside experience that could later be cashed out in lucrative private practice. ${ }^{23}$ Rather than encouraging an impartial search for the public interest, the collegial structure of the independent agency mired would-be policymakers in collective indecision. ${ }^{24}$ These criticisms of agency performance merged, sometimes imperceptibly, into a more radical critique of the New Deal ideal itself. This line of attack saw expertise as a myth concealing the inevitability of hard value choices, political insulation as a screen concealing the capture of the agency by special interests. ${ }^{25}$

Such critiques generated a predictable set of proposed remedies. On the one hand, there was an increasingly impatient demand that the agencies finally redeem their New Deal promise by generating clear standards through creative rulemaking. ${ }^{26}$ On the other hand, there

20. See Verkuil, The Emerging Concept of Administrative Procedure, 78 Couvm. L. Rev. $258,281-84$ (1978).

21. See, e.g., T. Lowi, The End of Liberalism (1969); President's Advisory Council on Executive Organization, A New Regulatory Framework (1971) (the "Ash Council" report); Cutler \& Johnson, Regulation and the Political Process, 84 YALE L.J. 1395, 1395-98 (1975) (citing other sources).

22. M. Bernstein, supra note 10, at 180-82; President's Advisory Council on Executive Organization, supra note 21, at 49 .

23. M. Bernstein, supra note 10, at 185; L. Kohlmeier, The Regulators 73 (1969).

24. President's Advisory Council on Executive Organization, supra note 21, at 34-43.

25. See, e.g., M. BERNSTEIN, supra note 10, at 155-60; T. LowI, supra note 21, at 72-93; J. Sax, Defending the Environment 52-56, 60-62, 107 (1970) (environmental area).

26. H. Friendly, The Federal Administrative Agencies 142-47 (1960); President's Advisory Council on EXecutive ORganization, supra note 21, at 34-35. 
was an increasing temptation to tinker with the institutional corollaries associated with the New Deal ideal. If existing agencies did not redeem New Deal ideals, perhaps some creative legislative or judicial responses would make a difference. ${ }^{27}$

Responding to the prevailing sense of unease, both courts and legislatures began experimenting with a wide variety of differentsometimes contradictory-solutions that promised to fill the legitimacy gap that had opened before them.28 Environmental law proved to be especially fertile ground for these proliferating experiments. ${ }^{29}$ When legal activists tried to give their environmental hopes statutory expression in the early seventies, their concrete experiences gave added point to the growing suspicion of New Deal models amongst the American establishment. ${ }^{30}$ Before 1970 , environmental protection was principally a matter for the states, rather than the federal government; and when environmentalists surveyed the state scene, the agencies they observed seemed to parody New Deal hopes. The typical state agency was so understaffed that it could not even pretend to understand the environment it was trying to regulate. ${ }^{31}$ Although state agencies frequently took

27. See, e.g., H. FRIENDLY, supra note 26, at 13-14, 163-73 (need for increased specificity in legislative definition of agency goals); Sive, Some Thoughts of an Environmental Lawyer in the Wilderness of Administrative Law, 70 CoLum. L. REv. 612, 614-19 (1970) (advocating increased judicial scrutiny of administrative actions). Once again, we have not tried to detail the trends we have described in all their complexity. For an excellent survey of the regulatory reform movement in all its aspects, see ABA CoMm'N ON LAW AND THE ECONOMY, FEDERAL REgulation: RoAds to REFORM (1979).

28. See, e.g., United States v. Florida East Coast Ry. Co., 410 U.S. 224, 240-42 (1973) (ratification of less formal agency procedures); Scenic Hudson Preservation Conf. v. Federal Power Comm'n, 354 F.2d 608, 620-25 (2d Cir. 1965) (remand to conduct more detailed proceedings). See generally $1 \mathrm{~K}$. Davis, Administrative Law Treatise $\$ 6.1$ (2d ed. 1978) (applauding widespread judicial innovation during 1970 s in review of agency rulemaking).

Congressional approaches have varied from attempts to influence regulation by supplementing the information considered by regulators, see, e.g., National Environmental Policy Act of 1969, Pub. L. No. 91-190, 83 Stat. 852 (1969) (codified at 42 U.S.C. \$§ 43214347 (1976)), to the direct specification of technical standards, see, e.g., 15 U.S.C. $\$ \$ 2001$ 2012 (1976) (automotive fuel efficiency standards), to phased deregulation, see, e.g., Airline Deregulation Act of 1978, Pub. L. No. 95-504, 92 Stat. 1705 (1978) (to be codified at 49 U.S.C. $\$ \S 1301-1308,1324,1371-1389$ ). See generally SENATE CoMm. ON GovernMental Opirations, Study on Federal Regulation, Sen. Doc. No. 25, 95th Cong., 1st Sess. (1977).

29. See, e.g., ABA COMM'N ON LAw AND THE ECONOMY, supra note 27, at 27; S. BREYER \& R. Stewart, supra note 19, at 283-85.

30. See, e.g., J. Esposito, Vanishing AIr 112-14 (1970); Stevens, Air Pollution and the Federal System: Responses to Felt Necessities, 22 HAstincs L.J. 661, 679-81 (1971). For an opposing view of the problems attributable to the New Deal agency, see Jaffe, The $A d$ ministrative Agency and Environmental Control, 20 BufFalo L. Rev. 231, 233-36 (1970).

31. See O'Fallon, Deficiencies in the Air Quality Act of 1967, 33 LAW \& CoNTEMP. ProB. 275, 286-96 (1968) (reviewing state agency resources and performance); Vaughn, State Air Pollution Control Boards: The Interest Group Model and the Lawyer's Role, 24 OrLA. L. REv. 25, 30-32 (1971) (insufficient budgets and inadequate staffing). 
the form of "independent" commissions, their membership was often dominated by the very interests that had most to gain from pollution. ${ }^{32}$

In response to this dismal reality, the $1970 \mathrm{Act}^{33}$ not only massively increases the federal presence, but takes steps to guard against the repetition of yet another New Deal failure. ${ }^{34}$ Instead of permitting a group of "independent" commissioners to run off in different directions, the Act places primary responsibility on a single Administrator squarely situated within the executive branch..$^{35}$

Just as the Act refuses to insulate the EPA in a New Deal fashion, so too it challenges the New Deal affirmation of expertise in two very different ways. First, the Act requires the Administrator to set quantitative clean air targets that would "protect the public health"38 while allowing for an "adequate margin of safety" and to reach these targets by 1977 at the latest. ${ }^{37}$ In taking this step, Congress forced the agency to specify its ends far more clearly than required by the New Deal model. No longer could expertise be used as an excuse for avoiding the inevitably controversial task of defining ultimate environmental objectives; instead, the agency must define its goals in a highly visible way and recognize that Congress will call it to account by a certain date if it finds its performance unsatisfactory.

At the same time it energetically pursued this ends-forcing strategy, Congress treated a second form of agency forcing in a more ambivalent way. Once having set air quality targets, the next step was to define the best means of achieving the clean air targets by 1977 . And at this stage, Congress was more reluctant to make a total break

32. See, e.g., J. Esposiro, supra note 30 , at 125 (state agency "acted like an underground chamber of commerce"). See generally Vaughn, supra note 31 , at $32-38$ (discussing methods of selecting state board members).

33. Clean Air Amendments of 1970, Pub. L. No. 91-604, 84 Stat. 1676 (current version at 42 U.S.C. $\$ \$ 7401-7642$ (Supp. II 1978)).

34. For an historical analysis of the passage of the Act that emphasizes precisely this challenge to New Deal ideals, see Marcus, Environmental Protection Agency, in THE Politics of Regulation 267, 267-74 (J. Wilson ed. 1980) (citing relevant sources).

35. Until 1970, air pollution control was the responsibility of the National Air Pollution Control Administration (NAPCA), an administrative subdivision of the Department of Health, Education, and Welfare. In July of that year, President Nixon submitted Reorganization PIan No. 3 of 1970 to Congress; upon becoming effective, the plan created the Environmental Protection Agency and transferred to the new agency most of the functions formerly vested in NAPCA. Reorg. Plan No. 3 of 1970, 3 C.F.R. $\$ 1072$ (19661970 Compilation), reprinted in 5 U.S.C. app., at 327 (1976), and in 84 Stat. 2086 (1970).

36. 42 U.S.C. $\$ 7409$ (Supp. II 1978).

37. For stationary sources, such as power plants, the Act originally envisioned attainment of its health-related targets by 1975 . See 42 U.S.C. $\$ 1857 \mathrm{c}-5(\mathrm{a})(2)(\mathrm{A})(1976)$. Heavily conditioned provisions could, however, stretch these formal deadlines by an additional two years, see 42 U.S.C. $\$ 7410$ (e) (Supp. II 1978), and individual plants might qualify for an extra year's grace, see 42 U.S.C. $\$ 1857 c-5(f)$ (1976) (amended 1977). 
with New Deal models. Indeed, so far as existing plants were concerned, Congress remitted the problem of defining individual cleanup obligations to a classical New Deal process: in a low visibility, highly discretionary process, state-level administrators, with federal assistance, develop a State Implementation Plan (SIP). ${ }^{38}$ The binding federal constraint is that, taken together, polluters within each airshed must reduce emissions sufficiently to bring local conditions into compliance with federal clean air targets. ${ }^{39}$ Because different airsheds have different air quality and contain different polluters with different cleanup costs, various SIPs require old plants to reduce their sulfur dioxide $\left(\mathrm{SO}_{2}\right)$ discharges in widely varying amounts. ${ }^{40}$ When viewed through New Deal eyes, this disparity is admirable. Because the pollution problem is of different severity in different parts of the country, why not ask polluters to cut back accordingly? If, due to local conditions, it is relatively expensive for coalburners to reduce their emissions compared to other dischargers, why not allow local compliance plans to take this factor into account? In principle, this decentralized process could harness the energies of knowledgeable experts to work effectively for the public good by designing reduction requirements to meet EPA air quality goals fairly and efficiently.

So far as new power plants are concerned, however, the Act makes a second and sharper break with New Deal ideals. Rather than encouraging policymakers to define each plant's cleanup obligations in the light of local environmental conditions, the Act's provisions for new source performance standards ${ }^{41}$ require all plants of the same type, regardless of their location, to meet the same emission ceiling for each

38. 42 U.S.C. $\$ 7410$ (a) (Supp. II 1978). See also W. Rodgers, Environmental LAw 233-35 (1977) (discussion of state processes and available federal assistance).

The critical feature of the SIP process is its reliance on air quality models that predict how a plant's emissions affect the air quality in its surrounding area. Due to these models' technical complexity, the EPA has provided states with a massive set of support documents as aids in the preparation of SIPs. See id. at 235-37.

39. 42 U.S.C. $\$ 7410$ (a)(2) (Supp. II 1978). If an area is already in compliance with the ambient air standards, the doctrine of prevention of significant deterioration (PSD) requires maintenance of existing levels of air quality. See Sierra Club v. Ruckelshaus, 344 F. Supp. 254 (D.D.C.), aff'd, 4 Envir. Rep. Cas. 1815 (D.C. Cir. 1972), aff'd by an equally divided court sub nom. Fri v. Sierra Club, 412 U.S. 541 (1973); cf. 42 U.S.C. $\$ 7491$ (Supp. II 1978) (seeking to prevent visibility deterioration).

40. Statewide average SIP requirements for coal-burning power plants range from 0.8 to 5.0 pounds of $\mathrm{SO}_{2}$ per million BTU produced. Memorandum from Tommy Holland, Energy Information Section, to John H. Haines, Assistant to Director, Emissions Standards and Engineering Division, EPA at 3 (May 23, 1978) (EPA Docket No. OAQPS-78-I, Item No. II-B-117). Individual plants in some states are allowed emissions ranging from 8 to 10 pounds per MBTU, using short-term averages. See, e.g., 40 C.F.R. $\$ \$ 52.1881(\mathrm{~b})(13)(\mathrm{i})$, (b)(23), (b)(28), (b)(33) (1979) (emission limits set by EPA for Ohio counties and sources). 41. 42 U.S.C. $\$ 7411$ (Supp. II 1978) (amending 42 U.S.C. $\$ 1857 c-6$ (1976)). 
pollutant. The Act also breaks with the New Deal paradigm by limiting the Administrator's freedom in setting the NSPS. Rather than contenting itself with the sententious advice to "protect the environment while assuring a vigorous economy," the original section 111 required the EPA Administrator to set effluent standards that could be satisfied by the "best system of emission reduction which (taking into account the cost of achieving such reduction) the Administrator determines has been adequately demonstrated." 42 Although, as we shall see, this formula is fairly elastic, its general thrust is plain. So far as new plants are concerned, Congress not only forced the EPA to specify its ends with clarity, but also presumed to specify the best means of achieving clean air objectives: only the "best system" would be acceptable in new plants.

To some extent, this insistence on better performance from new plants makes good sense. Old plants, after all, have often been designed with little or no thought to pollution control. New limitations would often require expensive retrofitting. In contrast, new plants can be designed from the start to take pollution reduction into account. ${ }^{43}$ But by lifting the NSPS process out of the general effort to tailor cutback requirements for existing plants to local environmental goals, the Act makes it easier for policymakers to push NSPS beyond the point of ecological justification. From the vantage point of the environment, it makes no difference whatever whether a pound of sulfur oxide is emitted by a power plant built before or after some magic date. ${ }^{44}$ Nor does it matter whether the sulfur is removed by a primitive hosing or by the most advanced gismo ever conceived by the mind of man. What matters is the impact of the sulfur oxide on the world outside the porver plant. And this depends not only on emissions but on a host of other factors-the height of the stack, the direction of the wind, and

42. Clean Air Amendments of 1970, Pub. L. No. 91-604, sec. 4(a), § 111(a), 84 Stat. 1676 (current version at 42 U.S.C. $\$ 7411$ (a) (Supp. II 1978)).

43. For example, control technology necessary to remove $\mathrm{SO}_{2}$ from smokestacks requires a relatively fixed amount of space within a plant near the smokestack. Because many plants built before 1970 did not anticipate the need to allow room for add-on technology, emission control is often more difficult and expensive for old plants than new ones. Retrofitting typically increases the original cost of control technology by $25 \%$ to $30 \%$. Sec National Academy of Sciences, Air Quality and Stationary Source Emission Control 451-54 (Comm. Print 1975) (prepared for House Comm. on Public Works, 94th Cong., Ist Sess.) [hereinafter cited as Stationary Source Emission Control].

44. From the vantage point of Congressmen from dirty air regions, however, uniform restrictions on new plants had additional attractions. NSPS meant that their states would be at less of a disadvantage in competing for new industry. See H.R. REP. No. 1146, 91st Cong., 2d Sess. (1970), reprinted in [1970] U.S. Code Cong. \& AD. News 5356, 5358; [1977] U.S. CODE Conc. \& AD. NEws 1263 nn.2 \& 4 (citing relevant sources), cf. Rose-Ackerman, Does Federalism Matter? 89 J. Political Econ. (forthcoming 1981) (discussion of strategic implications of federal system). 
the plant's proximity to population centers. ${ }^{45}$ Unless the EPA defined the "best system of emission reduction" to take account of these complexities, however, section 111 could be read to authorize a narrow inquiry into the technological design of the plant rather than a canvass of the ecological stakes involved in new construction. By giving statutory prominence to technological means of purification in new plants, section 111 would distort policymaking perceptions for years to come.

At this point, we begin to glimpse the complexity of the link between environmental symbol and administrative process. However ironic, it is the New Deal ideal that is consistent with the ecological insight into reality. For it is the expert agency, unencumbered by abstract legalisms, that promises to craft a policy responsive to the complexities of environmental relationships. Yet the one thing clear to the Act's draftsmen was that the New Deal agency had failed.

\section{From Statute to Policy}

In establishing its special regime for new plants, Congress intended to ensure that the interests of future generations would not be compromised by the passivity characteristic of the New Deal agency. The EPA, however, still had to translate the statute into practical policy. Its task was to establish a standard that, in the words of the statute, "reflects the degree of emission limitation achievable through the application of the best system of emission reduction which (taking into account the cost of achieving such reduction) the Administrator determines has been adequately demonstrated." 46 As we shall show, however, setting such a standard would have been tricky business at best; in its desire to avoid the perils of expertise, Congress had adopted a formula that was exceedingly difficult to apply to the facts presented by the coalburner. Unfortunately, however, the EPA did not respond to the inept statute by the creative use of its expertise, but instead treated NSPS as a problem in applied sanitary engineering.

\section{Technology in a Vacuum}

By its very terms, two aspects of the statute invited, if they did not require, agency sophistication in setting a standard for new coalburners. First, there is the instruction that the Administrator take cost "into account" in making his decision. A billion dollars is a lot of money, but it is a sensible investment if it purchases ten billion dollars

45. Stationary Source Emission Control, supra note 43, at 193-94, 624-34.

46. Clean Air Amendments of 1970, Pub. L. No. 91-604, sec. 4(a), § 111(a)(1), 84 Stat. 1676 (current version at 42 U.S.C. $\$ 7411$ (a) (Supp. II 1978)). 
in benefits. Rather than contemplating cost figures in the abstract, doesn't the language authorize an assessment of the net costs generated by a system after its environmental benefits have been taken into consideration? ${ }^{27}$ Second, a proposed system must be "adequately demonstrated" before it becomes the basis for a cleanup requirement. This phrase obscures difficult policy dilemmas. On the one hand, the EPA could have relied on new and untried cleanup technologies and take the risk that they would fail to work effectively. On the other hand, the agency could have satisfied itself with well-established technologies, and thereby lessen incentives to create new technologies that would improve cleanup performance. Yet there were creative possibilities for a statutory interpretation that would ameliorate, if not eliminate, this tension. For example, couldn't the agency have set a schedule of increasingly stringent requirements over an extended period of twenty or thirty years?

Unhappily, however, the agency did not try to ask, let alone answer, either of these questions. Instead, it read the statutory language as if a standard could be established on the basis of a narrow engineering judgment. To understand the bureaucracy's view of its own choices, we must consider the state of technology as it appeared in the early 1970s. At that time, there existed two methods for reducing emissions from coal-fired plants: a relatively old-fashioned technique known as physical coal cleaning, or "washing," 48 and an embryonic technology, flue gas

47. Courts have, with varying force, agreed with this proposition. Under a provision of the Federal Water Pollution Control Act, 33 U.S.C. § 1311(b)(2)(A) (1976) (limitations that require "best available technology economically achievable for such category or class, which will result in reasonable further progress toward the national goal of eliminating the discharge of all pollutants ... .), closely analogous to section 111 of the Clean Air Act, see p. 1479 supra, the Fourth Circuit has held that the EPA must compare the costs and ecological benefits of its chosen standard with those of alternative levels of heat reduction, or, at the very least, provide the "best information available" on the expected ecological benefits of the ordered reduction. Appalachian Power Co. v. Train, 545 F.2d 1351, 1364 (4th Cir. 1976); accord, National Crushed Stone Ass'n v. EPA, 601 F.2d 111, 121 (4th Cir. 1979), cert. granted, 100 S. Ct. 1011 (1980).

Although the Court of Appeals for the District of Columbia Circuit has not required the EPA to conduct cost-benefit analyses as part of the establishment of NSPS, Portland Cement Ass'n v. Ruckelshaus, 486 F.2d 375, 387 (D.C. Cir. 1973), cert. denied, 417 U.S. 921 (1974), it has required that the agency establish some minimal relationship between costs and expected benefits. Essex Chemical Corp. v. Ruckelshaus, 486 F.2d 427, 433 (D.C. Cir. 1973), cert. denied, 416 U.S. 969 (1974) ("best system" in section 111 means system that "can reasonably be expected to serve the interests of pollution control without becoming exorbitantly costly in an economic or environmental way"). The D.C. Circuit has also required that the EPA consider cost-benefit analyses submitted to it. Portland Cement Asss'n v. Ruckelshaus, 486 F.2d at 387 .

48. See generally Mitre Corp., The Physical Desulfurization of Coal 41 (1970) (Nat'1 Tech. Information Serv. Pub. No. PB-210-373). Before 1970, mines cleaned their coal primarily to remove impurities other than sulfur. The simultaneous removal of pyrites was an incidental benefit. See id. (more than half of U.S. coal production cleaned to some degree since before 1960 ). 
desulfurization, commonly known as "scrubbing." 49

Physical coal cleaning removes sulfur from coal before the coal is burned. Freshly-mined coal is crushed, passed through a screen, and wetted, so that heavy, sulfur-bearing fragments settle out. ${ }^{50}$ The relatively simple processes used to perform these functions remove most of the sulfur-bearing particles called pyrites that are physically mixed with the coal as it comes from the mine. ${ }^{51}$ They do not, however, remove sulfur that is chemically bonded to the coal.52 Nonetheless, the gains achieved by simple washing techniques can be substantial, varying from twenty to forty percent. ${ }^{53}$ Within these limits, physical coal cleaning is a cheap ${ }^{5 \pm}$ and reliable technology. Moreover, even more effective coal-washing techniques were being developed in the early 1970s. ${ }^{55}$

Nonetheless, the EPA disregarded such mundane methods and focused on more symbolically satisfying technologies-methods that would cleanse the smoke produced by coal-burning boilers. In 1971, only the scrubber performed these symbolic functions. Instead of relying on physical processes such as crushing and washing, a scrubber depends on the maintenance of a large-scale chemical reaction ${ }^{56}$ that

49. The first full-scale scrubber built in the United States began operation in 1968 and was abandoned in 1971. By the end of 1971, the nation's second and third scrubbers had begun operation. EPA, Report of the Hearing Panel: National Public Hearings on Power Plant Compliance with Sulfur Oxide Air Pollution Regulations 88-89 (1974) [hereinafter cited as REPORT OF the Hearing PANEL].

50. See Huettenhain, Yu, \&. Wong, A Technical and Economic Overview of Coal Cleaning, in 1 Proceedings: Symposium on Coal Cleaning to Achieve Energy and EnvironMENTAL GoAls 256, 259-74, $277-85$ (1979) (EPA Pub. No. 600/7-79-098a) (describing commonly used physical coal cleaning methods) [hereinafter cited as SYMPOsIUM on CoAI Cleaning].

51. Stationary Source Emission Control, supra note 43 , at 370.

52. Id.

53. Id. at 371 .

54. See p. 1523 infra.

55. By grinding coal into a finer slumy and using more sophisticated separation techniques, it is possible to wash out more of the pyritic sulfur than can be reached by the less sophisticated methods practiced in the early 1970s. J. Kilgroe \& J. Strauss, Use of Coal Cleaning for Air Quality Management 7-12 (Jan. 22-25, 1980) (unpublished paper presented at Second Conference on Air Quality Management in the Electric Power Industry, Austin, Tex.).

56. In a typical scrubber, as exhaust gases flow up a power plant smokestack, they are exposed to a lime or limestone solution that is sprayed in their path. Sulfur dioxide in the gas reacts with the spray and goes into solution, from which it is later removed, dewatered, and disposed of in the form of sludge. 2 EPA, Flue Gas Desulfurization System Capabilities for Coal-Fired Steax Generators 3-2 to 3-8 (1978) (EPA Pub. No. 600/7-78-032b) [hereinafter cited as FGD SYsTeM CaRabil.rTIEs]. On an average day, a typical scrubber will remove 190 tons of $\mathrm{SO}_{2}$ while consuming over 400 tons of limestone and thousands of gallons of water. Torstrick, Henson, \& Tomlinson, Economic Evaluation Techniques, Results, and Computer Modeling for Flue Gas Desulfurization, in 1 ProceED- 
requires continuous supervision..$^{57}$ Although early scrubbers removed about seventy-five percent of the $\mathrm{SO}_{2}$ in flue gases, ${ }^{58}$ they were prone to frequent breakdowns..$^{59}$ When the Administrator promulgated his new standard of performance in 1971, only three scrubbers were operating in the United States. ${ }^{60}$ The oldest, built in 1968, would be abandoned by the end of the year. ${ }^{61}$

In short, the EPA squarely confronted the problem posed by any statute that requires a finding that a system be "adequately demonstrated"-how to trade off certainty and economy against incentives for further technological development. Moreover, creative ways of mediating the tension were available; perhaps a standard based on improved washing should be required in the intermediate term, with reliance on scrubbers projected for a decade hence. Rather than giving the statutory formula a creative interpretation, however, the language was used as an excuse for thought. The possibility of advanced coal washing was never considered, and, in official documents, the agency narrowly focused its attention on the question whether the scrubber was "available" in some engineering sense, divorced from other development opportunities. ${ }^{62}$ Such an approach justified the bureaucracy in spending its limited resources on engineering projections that attempted to determine whether scrubbers could be made operational in the near future. On the basis of these projections, the Administrator determined that the capacity of scrubbers to eliminate about seventy percent of a coalburner's sulfur oxides ${ }^{\mathrm{\epsilon 3}}$ had been adequately demonstrated, and proceeded to the task of translating this engineering judgment into regulatory policy.

ings: Symposium on Flue Gas Desulfurization 118, 121, 134 (1978) (EPA Pub. No. 600/778-058a) [hereinafter cited as FGD Sxmposium]. In the early 1970s, few utilities possessed engineers capable of supervising these processes. STamionary Source Emission Control, supra note 43 , at 456 .

57. See FGD SySTEM CAPABILITIES, supra note 56, at 4-2.

58. EPA, Background Information for Proposed New Source Performance Standards 10-11 (1971) (coal-fired power plants) [hereinafter cited as 1971 BACKGround DocuninT].

59. FGD SYSTEM CAPABILITIES, supra note 56, at 4.13 (approximately $30 \%$ operability for systems built before 1973). Despite significant improvements since the early 1970s, id., system availability still troubles many plants. See EPA, EPA UTILITY FGD SURVEY: December 1978-January 1979 at x (1979) (EPA Pub. No. 600/7-79-022c) (in survey of plant operation over two-month period, half of systems had less than $50 \%$ reliability during at least one month).

60. 37 Fed. Reg. 5768-69 (1972).

61. Report of the HeAring PANel, supra note 49 , at 88.

62. See 1971 BAckground Document, supra note 58, at 16 (proposed standards are "insensitive to cost/benefit analysis when stack-gas cleaning is employed in that it is the only control system available").

63. 37 Fed. Reg. 5768-69 (1972). 


\section{Squaring the Circle}

It was at this point that the agency was forced to confront the dilemmas imposed by its own impoverished reading of the statute. The embarrassing fact is that the agency's interpretation made it conceptually impossible to move from its engineering judgment about the scrubber's availability to a definition of the quantity of sulfur oxides that new power plants would be allowed to discharge. To see why, merely reflect upon the fact that a power plant's emissions are a function of not one, but two, variables. Before the Administrator could tell the industry how many pounds of $\mathrm{SO}_{2}$ a plant could emit for each million BTU (MBTU) of energy it produced, it was not enough to determine that scrubbers could eliminate seventy percent of the sulfur in the coal. It was also necessary to determine the amount of sulfur in the coal that the plant burned. ${ }^{64}$ The engineering judgment was readily translated into an emission limitation only if all of America's coal contained the same sulfur content. For then seventy percent could be multiplied by a constant to yield a single nationwide limit on new plant discharges.

But, alas, America's coal reserves range from one to more than ten pounds in sulfur content. ${ }^{65}$ To make matters even more difficult for the Administrator, these coals are distributed unevenly throughout the coal-producing regions. Roughly half of the nation's reserves lie west of the Mississippi in the Northern Great Plains and Rocky Mountain

64. The British thermal unit (BTU) is a measurement of the amount of energy released by a coal when burned. A typical coal contains roughly 22 million BTU (MBTU) per ton.

The amount of sulfur found in a coal may be expressed either as a percentage of the total weight of the coal, or as the amount of sulfur that will be released per MBTU of heat released by the coal. Because coals vary substantially in heat content per pound, coals with the same percentage of sulfur by weight may generate different amounts of $\mathrm{SO}_{2}$ while producing the same amount of energy. The measurement of sulfur content in terms of pounds of sulfur dioxide produced per MBTU is a more meaningful index of a plant's discharge and will be used here whenever possible.

65. See McCreery \& Goodman, An Evaluation of the Desulfurization Potential of U.S. Coals, in Symposium on Cont Cleaning, supra note 50, at 387, 404 (characterizing coals on low end of scale); EPA, Sulfur Reduction Potential of U.S. Coals 28 (1976) (EPA Pub. No. 600/2-76-091) (fig. 16) (reprinting U.S. Dep't of Interior, Bureau of Mines, Pub. No. RI 8118) (showing extent of U.S. reserves containing more than 10 pounds per MBTU).

American reserves of coal are enormous, and there is little work that provides detailed characterizations of the combined sulfur content, heat content, and sulfur reduction potential of the United States reserve base. See EPA, Electric UTILITY STEAM GENERATing UNITS: BAckground Inforaration For Proposed $\mathrm{SO}_{2}$ Emission Standards 4-3 (1978) (EPA Pub. No. 450/2-78-007a) [hereinafter cited as $1978 \mathrm{SO}_{2}$ BAGKGround Information]. Although the U.S. Bureau of Mines has in its records a large number of detailed samples of coal reserves from various locations, further analysis is required to determine how well these samples represent the entire reserve base. See McCreery \& Goodman, supra, at 403.06 (reporting high degree of uncertainty in representativeness of previous studies). 
regions, and consist largely of low sulfur coal.66 Eastern reservesprimarily from the Midwest and the Appalachians-contain much higher proportions of higher sulfur coal. ${ }^{67}$

These facts signaled the bankruptcy of the engineering approach: it is mathematically impossible to multiply a constant by a variable to yield a single nationwide numerical ceiling on power plant emissions. The agency's predicament was intensified by a final statutory artifact. Although the statute directed the Administrator to look at the "best system" in defining applicable effluent standards, it did not authorize him to force polluters actually to install scrubbers if they could meet the effluent limit in some other way. ${ }^{68}$ Thus, whatever ceiling the Administrator might set, polluters might find it cheaper simply to burn low sulfur coal than to install scrubbers. The threat of a massive shift to lower sulfur coal would, in turn, generate powerful political pressures from the Eastern producers of high sulfur coal. The conceptual inadequacy of an engineering approach-its lack of explicit concern with the variability of polluting inputs-masked the potentially explosive political problem: how to parry the predictable counterattack by Eastern coal?

Not, surely, by surrendering without a fight. After all, the whole point of environmental regulation is to force producers to bear the social costs of their enterprise. High sulfur coal had previously gained an unfair competitive advantage over low sulfur coal precisely because the extra harm it caused the environment was not reflected in coal prices; a program of controlling sulfur oxides merely removed that advantage. ${ }^{60}$

Although this point is obvious in the abstract, it still had to survive the foreseeable counteroffensive by the Eastern high sulfur coal indus-

66. U.S. Energy Information Admin., supra note 3, at 123 (236 of 438 billion tons of coal in national demonstrated reserve base lie west of Mississippi River; unavailable figures based on extractable amount of heat might show lower proportion of national reserves because of lower heat content of many Western coals). Roughly $64 \%$ to $70 \%$ of all Western coal produces less than 1.2 pounds of SO. per MBTU. See 1978 SO. BickGROUND INFORMATION, supra note 65, at 4-6. Western coal has accounted for a small, but increasing, share of national production. 2 U.S. DeP'T OF INTERIOR, BuREAU OF Mines, Minerals Yearbook 1961 at 59 (1962); National Coal Ass'n, Coal Facts 80-81 (1978.79) $(5 \%$ in $1961,9 \%$ in $1971,24 \%$ in 1977) (all figures exclude Alaska).

67. Only $7 \%$ to $10 \%$ of reserves in the Eastern and Eastern Midwest regions produces less than 1.2 pounds of $\mathrm{SO}_{2}$ per MIBTU. $1978 \mathrm{SO}_{2}$ BACKGRound INFormatron, supra note 65 , at $4-6$.

68. See, e.g., S. REP. No. 1196, 91st Cong., 2d Sess. 17 (1970) (Administrator "should not make a technical judgment as to how the standard [of performance] should be implemented. He should determine the achievable limits and let the owner or operator determine the most economic, acceptable technique to apply.")

69. See generally A. Knesse, R. AYres, \& R. D'Arge, Economics and the Environment 84-85 (1970). 
try. The EPA could have tried to preempt this attack by showing that the threat to the industry was not nearly so great as a superficial analysis suggested. Or it might have demonstrated that the dangers of sulfur oxides were so intolerable that high sulfur mines could not reasonably hope to defend their competitive advantage in the political struggle that was sure to follow. But in its initial 1971 decision, the agency did not prepare the ground for the battle that, even then, was plainly perceptible to knowledgeable experts.

Despite the conceptual impossibility, and political unwisdom, of moving immediately from its engineering judgment to regulatory standards, the agency tried to square the circle by treating the problem of coal variability as if it were a minor detail. At no point did the agency explicitly recognize that its findings about scrubbing were compatible with an NSPS ceiling ranging all the way from 3 pounds per MBTU to 0.3 pounds per MBTU, depending on whether ten pound Eastern or one pound Western coal was being scrubbed at seventy percent efficiency. Apparently there was no effort, however rudimentary, to estimate the costs and benefits generated by a range of different possible emission ceilings. Instead the agency simply finessed its conceptual and political problems by announcing a number and making a few casual remarks in its support. The numerical ceiling was set at 1.2 pounds of $\mathrm{SO}_{2}$ per $\mathrm{MBTU} ;{ }^{70}$ in support, we were simply told that this ceiling would permit Eastern plants to scrub the average coal, which was said to contain about four pounds of sulfur per MBTU $([1-0.70] \times 4 \mathrm{lb}=1.2 \mathrm{lb}) .^{71}$ At the same time, the agency recognized that utilities might respond to this ceiling the natural way, by burning 1.2 pound coal. ${ }^{72}$ It entirely failed, however, to estimate the impact such decisions would have on the Eastern coal industry, let alone whether the benefits of the 1.2 standard outweighed its expected costs. ${ }^{73}$ Instead, it blandly proclaimed that burning low sulfur coal could also be used to satisfy the new standard. ${ }^{74}$

70. 36 Fed. Reg. $24,876-77$ (1971) (codified in 40 C.F.R. $\$ 60.43$ (1979)).

71. 37 Fed. Reg. 5767.71 (1972) (supplemental statement in connection with final promulgation; published after Kennecott Copper Corp. v. EPA, 462 F.2d 846 (D.C. Cir. 1972) (requiring more specific explanations of reasoning underlying EPA ambient air regulations)). The 4 pound per MBTU figure used in the text is inferred from the EPA's conclusion that the 1.2 standard was attainable by use of $70 \%$ scrubbing. The EPA actually expressed the sulfur content of the "average" coal as a percentage of the coal's weight, and not of its heat content. $C$ f. note 64 supra (explaining methods for measuring sulfur content of coal).

72. See 1971 Background Document, supra note 58, at 12.13 (low sulfur coal could be burned to meet standard, but not enough supply for all new and existing plants, and too expensive to ship to some areas).

73. See id. at 16.

74. Id. at 12. 
In short, a study of the EPA's 1971 decision suggests that Congress had succeeded only too well in transcending New Deal ideals of expertise. Rather than interpreting section 111 as requiring it to put costs into the context of environmental benefits, the agency fastened on the scrubber as a symbol of technological salvation. Rather than explaining to high sulfur producers why they must gradually give way before the public interest, the agency had assumed their problem out of existence.

Yet it was not as though EPA set out to make bad decisions. To the contrary, the EPA was responding rationally to the bureaucratic incentives created by the Act. In 1971, the EPA was an infant agency that had yet to create a reputation for itself; it confronted a clear congressional deadline requiring it to reach specified clean air targets by 1977 . If the EPA was to reach these targets, its prime problem was to force the states to force existing polluters to cut back on existing pollution, not to plan for plants coming on line in 1980 or 1990. To override the EPA's interest in establishing its credibility by acting in pursuit of short-term goals, section 111 would have had to require the agency to begin the lengthy and difficult task of long-range planning. Yet this effort to force the agency to confront economic and ecological complexity was the last thing Congress had in mind in moving beyond the New Deal. Rather than forcing the agency to redeem the promise of expertise, section 111 made it relatively easy for the EPA to treat NSPS as if it were an engineering problem.

Moreover, the agency's narrow reading of the statute was not to be remedied by the creative use of judicial review. This is not to say that the District of Columbia Circuit was altogether happy with the agency's performance. When the 1.2 standard was appealed by the utility industry, the court did sense that something was wrong with the agency's conception of its mission..$^{75}$ The particular fact that attracted judicial attention was the enormous quantity of sludge generated by a typical scrubbing operation. ${ }^{76}$ True to its mechanical reading of section 111, the agency had failed to take this second-order environmental harm into account before finding that scrubbing was qualified as the "best" method of emission reduction. This proved too much for the court of appeals, which remanded the matter to the EPA for

75. Essex Chemical Corp. v. Ruckelshaus, 486 F.2d 427, 441 (D.C. Cir. 1973), cert. denied, 416 U.S. 969 (1974).

76. Id. A single lime-limestone scrubbing system may produce several hundred thousand tons of sludge a year. EPA, Controlling $\mathrm{SO}_{2}$ Emissions from CoAl-Fired Steam-Electric Generators: SOLID WASTE IMPACT 14-18 (1978) (EPA Pub. No. 600/7-78-014a). 
explicit consideration. ${ }^{77}$ Unfortunately, however, the court did not recognize that the agency's disdain for the solid waste problem was only symptomatic of the abdication of its long-range planning function. ${ }^{78}$ As a result, the agency merely repromulgated its original NSPS standard, this time declaring explicitly that it had taken sludge into account. ${ }^{79}$

Although the agency's continuing neglect is readily explicable in terms of the bureaucratic needs of the moment, the sad story that follows owes a great deal to this bad beginning. The failure to create a sound structure for comparing costly means and environmental ends permitted partisans on both sides to pursue their interests without recognition of the larger aim-to fulfill our obligations to the next generation without causing unnecessary hardship for the Earth's present inhabitants.

\section{The Politics of Ignorance}

Operating under vague statutory mandates, New Deal agencies typically have ample opportunity to fend off congressional intervention by adapting to changing legislative sentiment through the use of administrative discretion.80 Within broad political constraints, agencies work out policy questions under the limited supervision of courts. In contrast, the Clean Air Amendments of 1970 tried to resolve so many disputable substantive questions that congressional intervention was soon required to respond to critical problems developing under the original act: ${ }^{81}$ major amendments were seriously considered in 1976 and passed in 1977.

Not that the interregnum between 1971 and 1976 is devoid of interest. During these years, scrubbing policy was disputed in several contexts-in a lawsuit dealing with new Western power plants, as an

77. 486 F.2d 427, 441 (D.C. Cir. 1973).

78. The court's notation of certain antipollution possibilities, however, see id. at 440 n.48 (use of low sulfur coal complies with emission standard without scrubbing); $i d$. at $441 \mathrm{n.51}$ (speculating on desirability of more flexible standard), might have suggested the need for broader consideration of net environmental benefits.

79. 40 Fed. Reg. 42,045, 42,047 (1975) (draft response to remand); 42 Fed. Reg. 61,541 (1977) (final promulgation of standards, declaring that "none of the comments persuaded the Agency to change the policy expressed in the September, 1975, draft response, i.e., that scrubber sludge can be fixated and disposal [sic] of in an environmentally acceptable manner at reasonable costs.")

80. Cf. J. LANDIs, supra note 10, at 68-69 (detailed delegation requires repeated amendment).

81. The most pressing issues were posed by the failure of automakers to comply with Congress' cutback requirements and the failure of the states to meet the Act's clean air targets in a timely fashion. See 7 ENVIR. REP. (BNA) 1288, 1304 (1977). 
administrative solution to the compliance problems raised by old plants, and as a possible way of preserving Western "clean air areas." These discussions placed scrubbing on the agenda when new plants returned to the forefront of congressional attention in 1976. Unfortunately, however, these agenda-setting activities narrowed the scope of inquiry and distorted the issues, obscuring the nationwide environmental implications of a forced scrubbing requirement.

Nor did the process of legislative revision serve to cure this defect. Rather than focusing attention on the world beyond Washington, D.C., a bizarre coalition of environmentalists and dirty coal producers tried to exploit congressional ignorance to serve their own, mutually incompatible, purposes. The result was a hopelessly incoherent mix of statutory language and legislative history, which set the stage for the most recent effort by the EPA to reconcile the law with the environment.

\section{A. Setting the Agenda}

After adopting its 1971 NSPS regulations, the EPA would have been happy to invest as little energy as possible in future planning. With the agency taking a passive role, outside litigants framed the issues for examination by the agency and the courts.

\section{The Navajo Challenge: The Distorting Prism of Adjudication}

The principal lawsuit grew out of a conflict between chapters of the Navajo tribe and one of the environmental movement's perennial targets-the complex of massive coal-burning facilities located near Four Corners, Arizona. ${ }^{82}$ Because low sulfur coal was readily available in the Southwest, the plants would be able to meet the 1.2 pound standard the natural way. The Navajo tribes argued that burning low sulfur coal was not sufficient under section 111 . They insisted that the EPA require the plants to install scrubbers, thereby reducing $\mathrm{SO}_{2}$ well below the 1.2 NSPS standard. ${ }^{83}$

From the vantage point of a litigator concentrating on Four Corners, this demand was but another battle in the long war to impose costly controls for environmental gains. From a national perspective, however, the issue was far more complicated-even granting environmentalist premises. Southwestern power plants would use Western low sulfur coal regardless of scrubbing requirements for the simple reason

82. Oljato Chapter of the Navajo Tribe v. Train, 515 F.2d 654 (D.C. Cir. 1975).

83. See Letter from Joseph J. Brecher, Native American Rights Fund, to William D. Ruckelshaus, Administrator, EPA at 3 (March 20, 1973) (on file with Yale Law Jottmal) (request on behalf of Indian tribes that EPA issue notice of proposed rulemaking to revise 1971 NSPS for power plants). 
that, when shipping costs were taken into account, this was by far the cheapest coal available. Yet, although a seventy percent scrubbing requirement ${ }^{84}$ would reduce Four Corners' emissions by seventy percent, this would hardly be the outcome of a nationwide requirement. In the East and Midwest, many plants would have a choice between nearby high sulfur coal and more distant low sulfur varieties. If the ceiling remained at 1.2 and scrubbing were required by law, these utilities would lose all economic incentive to pay the costs of shipping low sulfur coal. Instead, they would use their seventy percent scrubbers on the four-pound coal readily available nearby. Burning low sulfur coal without scrubbing might be the cheaper and more natural way to achieve the same result. Thus, forced scrubbing promised to be a symbolically satisfying but peculiarly inefficient response to the realities of coal burning. Moreover, a massive shift to scrubbing would place enormous burdens on the EPA inspection system. Scrubbers only scrub when operated; unless EPA mounted an ongoing and credible enforcement effort, the shift to high sulfur coal might even increase $\mathrm{SO}_{2}$ loadings in some populous regions east of the Mississippi. ${ }^{85}$

Given their narrow focus on Four Corners, however, the Navajo had no need to concern themselves with the impact of scrubbing on the other side of the country. Worse yet, when the Navajo went to court to force the EPA to impose scrubbers, the agency did not try to defend its 1971 decision on the merits. Although there is evidence that agency specialists were aware of the costs of inducing a shift away from low sulfur coal in the East, ${ }^{86}$ agency lawyers chose to defend EPA's 1971 decision on a narrow procedural ground. In this they were successfulthe District of Columbia Circuit rejected the Navajo challenge, ${ }^{87}$ re-

84. In addition to arguing that scrubbers be required, the Navajo argued that scrubbers were capable of $90 \%$ sulfur removal, rather than approximately $70 \%$ as concluded by the EPA. Id. We use the EPA's determination of demonstrated capabilities in the present example.

85. See pp. 1526-28 infra.

86. See, e.g., Letter from John R. Quarles, Jr., Acting Administrator, EPA, to Martin Green, Dep't of Justice (Jan. 23, 1974) (on file with Yale Law Journal).

87. Oljato Chapter of the Navajo Tribe v. Train, 515 F.2d 654, 661, 666 (D.C. Cir. 1975) (dismissal for failure to seek administrative review prior to initiation of suit). The Navajo attempted to sue the agency under $\$ 304$ of the Act, 42 U.S.C. $\$ 7604$ (Supp. II 1978), on the theory that failure to revise an arguably invalid standard constituted a failure to fulfill a nondiscretionary duty. The court rejected this theory, but indicated that the Navajo ultimately might obtain judicial review of the NSPS after petitioning the Administrator under $\S 307$. Following this initial defeat, the Navajo, joined by the Sierra Club, renewed efforts to reduce Western emissions by following a different procedural course. In early 1977, the EPA agreed to the groups' request for formal reconsideration of the 1971 NSPS. See 42 Fed. Reg. 5121 (1977). The reconsideration process had barely begun, however, by the time Congress enacted its own revisions to $\$ 111$ as part of the Clean Air Act Amendments of 1977, Pub. L. No. 95-95, sec. 109, $\$ 111,91$ Stat. 685 (codified at 42 U.S.C. $\$ 7411$ (Supp. II 1978)). 
lieving the agency of the immediate need to invest more energy in the scrubber. Unhappily, however, the lawyers' strategic victory deprived the agency of a critical opportunity to educate its public. Although Four Corners dramatized the way scrubbing might reduce Western emissions, no similar event would dramatize the disadvantages of a high-technology strategy in the East.

\section{The Struggle over Existing Plants}

While the new plant standards were left on the back burner, the more immediate battle over old plant emissions engaged the attention of all participants. ${ }^{88}$ By fixing environmentalists' attention upon scrubbing as a technological solution, this struggle left its mark on the later revision of NSPS.

The immediate sulfur oxide problem was posed by existing coal-fired plants, which contributed about half of the overall load of sulfur oxide in the United States in $1972 .{ }^{89}$ If the Act's promise of clean air was to be redeemed, many of these plants would have to cut their emissions substantially..$^{90}$ Moreover, under the law, each plant's lawful emissions could be determined only after a state agency had calculated the cutback required to assure regional compliance with the ambient standards for sulfur dioxide. ${ }^{91} \mathrm{~A}$ set of exhausting courtroom battles lay ahead. ${ }^{92}$

Predictably, utilities tried to minimize the cost of the changes required of them. Instead of building scrubbers or burning low sulfur coal, a coalburner could reduce its effective contribution to the local sulfur oxide problem by building "tall stacks," up to 1000 feet high,

88. The compliance problems of existing power plants were widely studied at this time. See, e.g., Rerort of the Hearing PANel, supra note 49; ADministrator of EPA, Control of Sulfur Oxides, S. Doc. No. 59, 94th Cong., 1st Sess. (1975) [hereinafter cited as Control of Sulfur Oxides]; EPA, Position Paper on Regulation of Atmospheric Sulfates (1975) (EPA Pub. No. 450/2-75-007) [hereinafter cited as Position Paper]; Stationary Source EMIssion Control, supra note 43, at 193-711 (1975). Only the EPA's position paper gave more than a glancing look to the problems posed by strategies to control new plants. See Position Paper, supra, at xvi-xix, 60-80.

89. EPA, 1972 National Emissions Report 1 (1974) (EPA Pub. No. 450/2-74-012).

90. In the fall of $1973,70 \%$ of the nation's coal- and oil-burning power plants emitted more $\mathrm{SO}_{2}$ than allowed by the proposed SIPs. EPA, EPA ENForceMent: A Progress REPORT: 1976 at 12 (1977). Following revisions in the original SIPs, the EPA estimated that in 1975 at least $40 \%$ of the coal-burning capacity in the U.S. would require emission reductions to comply with primary air quality standards. REPORT OF THE HEARING PANEL, supia note 49 , at 14 .

91. Pub. L. No. 91-604, sec. 4(a), $\$ 110,84$ Stat. 1676 (current version at 42 U.S.C. $\$$ 7410(a)(2) (Supp. II 1978)); see W. RodGers, supra note 38, at 235-37 (description of complex factors on which SIP emission limitations are based).

92. By late 1973 it was already apparent that most coal-burning power plants would not meet the original mid-1975 deadline. Report of the Hearing Panel, supra note 49, at 3. By 1975, the EPA was no longer planning for full compliance by June of that year or even by 1977, but by 1980 . Control of Sulfur Oxides, supra note 88, at 1-6. 
thus increasing the speed at which its gases diffused beyond the air quality region in which it was located. ${ }^{93}$ To respond to the temporarily higher concentrations created by inversions or other unfavorable meteorological conditions, the utilities proposed an "intermittent control strategy." They would hold a reserve of low sulfur fuels to burn during inversion periods. Alternatively, during an air pollution emergency, they would bring their cleanest plants on line first to meet peak demand conditions. ${ }^{04}$

The environmentalists predictably responded to these proposals with alarm. Tall stacks, they rightly feared, would improve local conditions only at the expense of more distant regions. ${ }^{25}$ They also opposed the utilities" use of "intermittent controls," 96 which imposed significant burdens on future efforts to monitor compliance. ${ }^{97}$ In response to these fears, environmental groups brought suit to challenge the legality of the utilities' strategies under the Clean Air Act.98 Once again, the exigencies of litigation obscured the real problems raised by sulfur emissions. Although the EPA recognized that the long-range transport of sulfur oxides raised serious policy problems, ${ }^{99}$ environmentalists did not concentrate on forcing the EPA to channel its energies in long-term

93. See Stationary Source Emission Control, supra note 43, at 212-16. In 1975, a tall stack was estimated to cost $3 \%$ to $17 \%$ of the cost of a scrubber. Id. at 210,215 . At least fifteen states provided credit for the use of tall stacks in 1974. See Clean Air Act Oversight: Hearings Before the Subcomm. on Environmental Pollution of the Senate Comm. on Public Works, 93d Cong., 2d Sess. 320, 330 (1974) (statement of Richard Ayres) [hereinafter cited as 1974 Senate Oversight Hearings].

94. See, e.g., Implementation of the Clean Air Act-1975: Hearings Before the Subcomm. on Environmental Pollution of the Senate Comm. on Public Works, Pt. 2, 94th Cong., 1st Sess. 1417-21 (1975) (statement of Donald G. Allen, New England Electric System, presenting discussion by James $\mathrm{R}$. Mahoney, consultant) [hereinafter cited as 1975 Implementation Hearings].

95. See, e.g., Clean Air Act Amendments of 1977: Hearings Before the Subcomm. on Health and the Environment of the House Comm. on Interstate and Foreign Commerce, 95th Cong., 1st Sess. 493 (1977) (statement on behalf of Izaak Walton League of America) (opposing tall stacks because of acid rain and sulfates) [hereinafter cited as 1977 House Hearings]; Ayres, Enforcement of Air Pollution Controls on Stationary Sources under the Clean Air Amendments of 1970, 4 Ecologx L.Q. 441, 452-54 (1975) (describing "environmental bankruptcy" of dispersion strategy).

96. See 1975 Implementation Hearings, supra note 94, at 1899 (letter from League for Conservation Legislation); Ayres, supra note 95, at 452-55.

97. See 120 CoNG. REc. 18,960 (1974) (reprinting memorandum from EPA enforcement division). Environmental groups based their objections, in part, on the difficulty in proving that a utility had failed to burn low sulfur coal or to comply with a complex dispatching algorithm. See 1975 Implementation Hearings, supra note 94, at 1313-14 (statement of Benjamin Wakes, Montana Dep't of Health and Environmental Sciences); 1974 Senate Oversight Hearings, supra note 93, at 320, 325-26 (statement of Richard Ayres).

98. See, e.g., NRDC v. EPA, 489 F.2d 390, $406-09$ (5th Cir. 1974), rev'd in part on other grounds sub nom. Train v. NRDC, 421 U.S. 60 (1975) (Clean Air Act permits use of dispersion techniques such as tall stacks only where methods of emission reduction unavailable or unfeasible).

99. Posrrion Paper, supra note 88, at xv-xix. 
directions. ${ }^{100}$ Instead, they sought solutions more readily obtainable through judicial decree. Moreover, the desire to attain rapid compliance with $\mathrm{SO}_{2}$ standards produced a peculiar faith in technological solutions. Rather than pressing power plants to use low sulfur fuel, environmentalists emphasized scrubbing as their preferred remedy to utility footdragging. ${ }^{101}$

While implementation of any cleanup strategy awaited the outcome of litigation, ${ }^{102}$ the rhetorical battle over scrubbing-both in and out of court-heated up. The utilities insisted that scrubbers were unreliable, ${ }^{103}$ and environmentalists increasingly viewed scrubbers as the final solution to the utilities' unreasonable delays. ${ }^{104}$ Thus, the oldplant dispute evolved in a way that mocked the SIP process' aspirations to tailor cleanup burdens in a way that was sensitive to local environmental realities. Rather than forcing EPA to beef up its enforcement operation and consider the problem of long-range transport, the critical issue was increasingly perceived to be the viability of a single technology. And, although the issue was initially considered in connection with old plants, ${ }^{105}$ the scrubber "solution" was present in the minds of policymakers when new plants came to the fore.

\section{B. The Glean Air-Dirty Coal Coalition}

New plant scrubbers had been discussed, in the years between 1971 and 1976, in contexts that precluded full examination of the nation-

100. For example, Ayres criticized the EPA's attempts to use complex diffusion models to produce a closer fit between ambient air criteria and control requirements. See Ayres, supra note 95, at 468-69.

101. See, e.g., 1975 Implementation Hearings, supra note 94, at 1899 (letter from League for Conservation Legislation); 1974 Senate Oversight Hearings, supra note 93, at 320, 320 24 (statement of Richard Ayres); Ayres, supra note 95, at 443-49.

102. By the end of 1976 , only $59 \%$ of the nation's power plants were operating in full compliance with sulfur oxide emission limitations or meeting federally enforceable schedules. EPA, EPA Enforcement: A Progress RePort, 1976, supra note 90, at 12. Of the plants comprising the remaining $41 \%$, many operated in areas where challenges to SIPs remained unresolved. Id.

103. 1975 Implementation Hearings, supra note 94, at 1421 (statement of Donald Allen, New England Electric System); id. at 143I, 1439-40 (statement of Electric Utility Industry Clean Air Coordinating Committee, 61 investor-owned utility companies); 1977 House Hearings, supra note 95, at 1365, 1383 (statement of A. Joseph Dowd on behalf of Edison Electric Institute); 6 ENvir. REP. (BNA) 1300 (1975) (utility representatives' statements to panel of National Governors' Conference energy officials).

104. See note 101 supra.

105. See, e.g., Clean Air Act Amendments-1975: Hearings Before the Subcomm. on Health and the Environment of the House Comm. on Interstate and Foreign Commerce, 94th Cong., Ist Sess. 34, 39-40 (testimony of Russell E. Train); id. at 826-27 (testimony of representative of Nat'l Coal Association); Clean Aiv Act Oversight-1973: Hearings Before the Subcomm. on Public Health and Environment of the House Comm. on Interstate and Foreign Commerce, 93d Cong., Ist Sess. 13, 16-17 (1973) (testimony of John A. Quarles, Jr., Acting Administrator, EPA). 
wide dimensions of the problem: the Four Corners suit against Western coalburners and the struggle for SIP compliance by old plants. While preparing amendments to the Act in response to industry's failure to meet statutory deadlines, ${ }^{106}$ the House subcommittee permitted the controversies of the Act's first five years to define the problems that were worthy of attention. Rather than considering NSPS on its own merits and taking steps to beef up the EPA's effective capacity for long-term planning, the subcommittee used the scrubber as a symbolically satisfying way of responding to other more pressing political needs.

\section{The Clean Air Regions}

The treatment of new coal-burning plants did not emerge directly upon the legislative agenda. Instead, it attracted the attention of congressional staffers as they grappled with a far more pressing issue-the treatment of the "clean air regions."

Although the 1970 Act had established minimum air quality objectives for the nation, ${ }^{107}$ many areas in the nation already enjoyed air far cleaner than the Act required. ${ }^{108}$ Yet the original draftsmen did not focus clearly on the problem posed by this embarrassment of riches. In these areas, did the 1970 Act amount to a Dirty Air Act legitimating pollution up to the minimum standards? When EPA began to approve SIP's that permitted power plants to degrade clean air regions, the Sierra Club went to court to challenge the legality of this decision. It emerged victorious by a narrow margin. After it convinced a single district judge of the impropriety of the Administrator's decision, this outcome was sustained by an equally divided Supreme Court. ${ }^{109}$

Unless Congress amended the statute, the litigation meant that EPA could not approve state plans which permitted increases in the levels of pollutants in the clean air areas. Although environmentalists strongly

106. See note 81 supra.

107. See 50 C.F.R. $\$ \S 50.4$ to 50.5 (1979) (air quality standards for sulfur oxide). The areas west of the Mississippi have been a special focus of environmentalist concern. See Nondegradation Policy of the Clean Air Act: Hearings Before the Subcomm. on Air and Water Pollution of the Senate Comm. on Public Works, 93rd Cong., Ist Sess. 5, 7 (1973) (statement of Laurence Moss, President, Sierra Club) (discussing Southwest, Rocky Mountains, and Northern Great Plains). Their $\mathrm{SO}_{2}$ levels are generally lower than the national average. See Stationary Source Emission Control, supra note 43, at 238.

108. Most of the air quality regions in the country were in compliance with annual and twenty-four hour $\mathrm{SO}_{2}$ standards. EPA, Monitoring and AIR Quality TREnds Report, 1974 at 15 (1976) (EPA Pub. No. 450/1-76-00I) (16\% of stations violated annual standard in $1970,9 \%$ in $1974 ; 11 \%$ violated 24 -hour standard in $1970,5 \%$ in 1974).

109. Sierra Club v. Ruckelshaus, 344 F. Supp. 253 (D.D.C.), aff'd, Envir. Rep. Cas. 1815 (D.C. Cir. 1972), aff'd by an equally divided court sub nom. Fri v. Sierra Club, 412 U.S. 541 (1973). 
supported this course, it became apparent that their objectives would evoke concerted opposition by groups interested in Western economic development. ${ }^{110}$ Searching for ways of packaging environmentalist objectives in politically acceptable forms, House staffers working under Congressmen who supported the protection of clean air areas turned to the solution advanced by the Navajos' abortive lawsuit at Four Corners-a scrubbing requirement for all new plants. Even if the highly visible provisions mandating "nondegradation" of the clean air areas succumbed to political counterattack, requiring all new coalburners to scrub would reduce the overall level of Western emissions, thus providing secondary protection to the endangered clean air regions.

\section{The House Proposals of $\mathbf{1 9 7 6}$}

Universal scrubbing, in short, would provide a second line of statutory defense for the clean air regions. Thus, when amendments were initially proposed by the subcommittee, they contained not only an elaborate effort to preserve the clean air regions but also a barely perceptible alteration of section 111. As we have seen, the 1970 version of this section directed the agency to set performance standards that reflected "the degree of emission limitation achievable through the application of the best system of emission reduction ...."111 In contrast, the new House proposal required a standard that "reflects the degree of emission reduction achievable through the application of the best technological system of continuous emission reduction ....".112

The significance of this change was far from obvious, given the special definition of "technological system of continuous emission reduction" that also appeared in the House proposals. Rather than defining the term to require an "add-on" pollution control technology, section $111(a)(7)$ gave the term a technical meaning: "a technological process for production or operation by any source which

110. See, e.g., 1975 Implementation Hearings, supra note 94, at 862-65 (statement of J.D. Geist, Exec. Vice President, New Mexico Public Service Co.) (need to amend 1970 Act to negate Sierra Club v. Ruckelshaus interpretation and avoid preclusion of "further development of my State's vast energy resources"); $i d$. at 1984-85 (statement of E. Allan Hunter, President, Utah Power and Light Co.) (Sierra Club v. Ruchelshaus means "continued poverty in many rural areas of the west" and "inability to develop our own resources").

11. Clean Air Amendments of 1970, Pub. L. No. 91-604, sec. 4, $\$ 111,84$ Stat. 1676 (current version at 42 U.S.C. $\$ 7+11$ (Supp. II 1978)) (emphasis added).

112. H.R. 10498, $\$ 111$ (a)(1)(C), reprinted in H.R. REP. No. 1175, 94th Cong., $2 \mathrm{~d}$ Sess. 310 (1976) (enacted as Pub. L. No. 95-95, sec. 109(c)(1)(A), §111(a)(1)(C), 91 Stat. 685 (1977) (emphasis added). 
is inherently low-polluting or nonpolluting." 113 And the use of low sulfur coal seems precisely the kind of step suggested by this explicit definitional extension. ${ }^{114}$ If anything, this explicit language placed the use of low sulfur coal on a more solid statutory foundation than before.

Turning to the House committee report, however, one enters a new world of meaning. The report explicitly proclaims that scrubbing or some other "add-on" technology is required of all new coalburners. The statutory definition of "technology" to embrace the operation of "low-polluting or nonpolluting sources" is explicitly denied-without explanation-to the typical user of low sulfur coal. ${ }^{115}$ This clear statement would bear fruit only if the EPA and the courts focused their attention upon the committee report, glancing at the statute itself only when the report's language was ambiguous. Unfortunately, this approach to statutory interpretation is hardly unprecedented. ${ }^{116}$ If the legislative history were to be taken seriously by the courts, the equation of a "technological system" with scrubbing would serve the subcommittee's purpose of providing low visibility insurance for the clean air areas.

\section{The Uses of Technocratic Intelligence}

As the House committee position evolved in 1975 and early 1976 , the committee staff turned to the executive branch for data in support of its proposals. ${ }^{117}$ The EPA modelers' principal task was to examine the impact of the elaborate new provisions that had been designed to prevent the significant deterioration of air quality in clean

113. Id. $§ 111(\mathrm{a})(7)$, reprinted in H.R. REP. No. 1175, 94th Cong., 2d Sess. 310-11 (1976) (enacted as Pub. L. No. 95-95, sec. 109(c)(1)(B), \$111(a)(7), 91 Stat. 685 (1977) (codified at 42 U.S.C. $\$ 7411$ (a)(7) (Supp. II 1978)) (emphasis added). According to the House report, this definition refers "to any technology which is inherently low polluting or non-polluting (e.g., fluidized bed combustion, use of water-based paints instead of solvents, etc.). ..."Id. at 161 .

114. Use of low sulfur coal may reduce emissions from a boiler previously using high sulfur coal by up to $75 \%$. See p. 1483 supra.

115. The report states that a source "may no longer meet NSPS requirements merely by use of untreated oil or coal," presumably because it is not "technological." H.R. REP. No. 1175, 94th Cong., 2d Sess. 161 (1976) [hereinafter cited as 1976 House RePorT].

116. See Frankfurter, Some Reflections on the Reading of Statutes, 47 Colum. L. REv. 527,543 (1947).

117. See EPA, A Preliminary Analysis of the Economic Impact on the Electric Utility INDUSTRY OF AlTERnative APPRoAches to Significant DETERIORATron (1976) (Nat'l Tech. Information Serv. No. PB 251 394) [hereinafter cited as EPA Preliminary ANalysis]; EPA \& Federal ENergy Admin., AN ANAlysis of THe IMPact on the Electric Utility INDUSTRY OF Alternative ApProaches to Significant DETERIoration (1975) (Nat'l Tech. Information Serv. No. PB 246 205) [hereinafter cited as EPA-FEA ANALYsis]. 
air regions-PSD, as it is known in the trade. ${ }^{118}$ But the EPA staff also cast a side-long glance at the House efforts to impose universal scrubbing through section 111. Rather than using their expertise to redefine the problem as it was perceived by busy laymen on Capitol Hill, however, the EPA staff work proceeded within the framework of congressional understanding. It failed to address the environmental risks of scrubbing high sulfur coal in the East, ${ }^{119}$ which had not yet gained a high place in EPA consciousness. Moreover, it failed to assess the possibility of achieving emission reductions more cheaply by lowering the 1.2 ceiling rather than requiring all coalburners to use scrubbers. Thus, it presented a false dichotomy: universal scrubbing was treated as if it were the only alternative to the EPA's existing 1.2 standard. ${ }^{120}$ Because cheaper ways of achieving lower emission levels had been excluded a priori, the formal analysis made it appear that Congress was buying some real sulfur oxide emission reductions by forcing scrubbing on the utility industry. ${ }^{121}$

Despite its narrow focus, the technocratic report was hardly an unqualified endorsement of the subcommittee's innovation. It emphasized that the invisible amendment to section 111 was a very expensive proposition-adding, by 1990, 14 billion dollars over the level of expenditure required in the name of PSD. ${ }^{122}$ Moreover, the EPA's projections suggested that demand for Eastern coal would grow over the next twenty years even without the artificial respiration provided by the scrubber. ${ }^{123}$

118. See EPA Preliminary ANalysis, supra note 117, at I-1 to I-4; EPA-FEA ANalysis, supra note 117 , at $1-3$.

119. See EPA Preliminary ANALYsis, supra note 117, at V-17 (analysis of nationwide emissions only).

120. See id. at I-3 to I-4 (discussion of policy alternatives).

121. Id. at V-17. The EPA predicted that a universal scrubbing requirement would result in a 1990 emissions level, nationwide, $22 \%$ lower than the level that would result from a 1.2 standard. Even without scrubbing, emissions were predicted to decline, relative to 1974 levels. The EPA study noted that almost no reduction in national emissions beyond those produced at a 1.2 standard was required to meet PSD requirements. Id. at V-1 (table V-1). Instead, the EPA predicted that site selection for new plants could maintain low levels of $\mathrm{SO}_{2}$ in clean air regions. $l d$. at V-2.

122. $I d$. at $\mathrm{V}-8$.

123. Id. at V-5. Western production would increase tenfold by 1990 over 1974 production of 64 million tons, but mines in the Appalachians and Midwest (including for these purposes Arkansas and Oklahoma) would enjoy an increase from 531 million tons in 1974 to 680 million tons in 1990 . Id. The Appalachian region's production would grow by $45 \%$, $i d$., while the output of Midwest coal-higher in sulfur content and closer to the lowsulfur West-would decline by $15 \%$ from 149 to 125 million tons in 1990 . Suspiciously, the EPA predicted that universal scrubbing would almost precisely offset the Midwestern reduction-promising an additional 25 million tons of sales in 1990 . In the East and Midwest combined, however, this 25 million ton gain is less than $5 \%$ of present production and no more than $17 \%$ of the total growth projected for the region under full scrubbing. $I d$. 


\section{Dirty Coal and Clean Air Converge}

The EPA report hardly suggested that the scrubber was a life-anddeath issue for Eastern coal. Nonetheless, Eastern interests were predictably receptive to the House subcommittee's "new" NSPS proposal when the subcommittee's staff went searching for politically potent allies. ${ }^{124}$ Although universal scrubbing had only a problematic relation to clean air goals, dirty coal producers valued the proposal in its own right. If Eastern utilities were forced to install scrubbers, it would be possible for them to meet the 1.2 NSPS while continuing to buy cheap high sulfur coal. It was only if utilities remained free to substitute low sulfur coal for scrubbers that a shift away from high sulfur coal was even conceivable. Thus, it made sense for the dirty coal producers to abandon their campaign to weaken pollution standards and take up the cudgels for the costliest possible clean air solution-universal scrubbing. ${ }^{125}$ In so doing, Eastern coal interests abandoned their traditional alliance with utilities whose interests lay in minimizing the expense of pollution control requirements.

The stage had been set for a bizarre convergence of clean air and dirty coal forces. The subcommittee had originally turned to scrubbing as an ancillary environmentalist measure in support of PSD, and viewed the coal lobby merely as a convenient ally in the battle for clean air. But once the attention of the coal lobby had been engaged, the scrubbing issue took on a life of its own in the service of regional protectionism. This peculiar political marriage is evident in the 1976 House

124. The anxiety of Eastern coal producers must be understood in light of the recent past as well as the foreseeable future. Although the EPA data, see note 123 supra, showed that Eastern coal would increase production even without universal scrubbing, Eastern coal had recently suffered market cutbacks at the hands of clean air. In the 1960s, Northeastern states had dramatically cut back on the sulfur emissions they would tolerate, and at the same time, oil import quotas were eliminated. Northeastern utilities substituted imported low sulfur oil for Eastern high sulfur coal. As a consequence, coal shipments to power plants on the Atlantic coast, from Maine to Virginia, fell from 40 million tons (70.3\% of all utility fuel burned) in 1964 to 15.4 million tons $(15.7 \%$ ) in 1973. See Nondegradation Policy of the Clean Air Act: Hearings Before the Subcomm. on Air and Water Pollution of the Senate Comm. on Public Works, supra note 107, at 141-49. Although this collapse in the market was offset by gains in sales of Eastern coal in other areas, resulting in gradual increases in production over the period from 1964 to 1973, 1 U.S. DIP'T OF THE INTERIOR, BUREAU OF MiNes, I973 MiNerALS YeARbOOK 326 (1975) (production statistics); 2 U.S. Def't of The Interior, Bureau of Mines, 1964 Minerals Yearbook 59 (1965) (same), the Eastern coal producers had been taught a lesson they would not quickly forget.

125. The United Mine Workers, whose membership is concentrated in the East, had no difficulty coming out publicly for universal scrubbing. See 1976 House REPORT, supra note 115, at 163. The National Coal Association, comprising both Western low-sulfur and Eastern high-sulfur producers, refused to take a position on scrubbing, leaving individual companies free to make their views felt. Interview with representative of National Coal Association, in Washington, D.C. (Sept. 21, 1979). 
committee report, ${ }^{126}$ whose language was repeated in the House report the following year. ${ }^{127}$ The text, reproduced in the margin, justifies forced scrubbing by finding six flaws in the existing approach to NSPS. ${ }^{128}$ Although the critique was written by House staffers with strong environmentalist reputations, its author might as easily have come from one of the major coal producers. While the final point in its bill of particulars attempts an inadequate invocation of technology forcing, ${ }^{129}$ the report resembles the standard rhetoric of the Eastern coal lobby-the need to eliminate unemployment by using "locally available fuels" and to defeat the energy crisis by burning high sulfur coal. ${ }^{130}$ The committee report, moreover, contains no data to support this rhetoric and does not discuss the inconsistent analysis that had been proffered by EPA.

Although the House report established the basis for a clean air-dirty coal coalition, it remained for the environmental lobby in Washington,

126. 1976 HOUSE REPORT, supra note 115 , at 160 .

127. H.R. Rep. No. 294, 95th Cong., Ist Sess. 187 (1977).

128. The report argues that the standards of performance for $\mathrm{SO}_{2}$ established in 1971, see p. 1485 supra, violate the purposes of the Act because

1. The standards give a competitive advantage to those States with cheaper low sulfur coal and create a disadvantage for mid-western and eastern States where predominantly higher sulfur coals are available;

2. These standards do not provide for maximum practicable emission reduction using locally available fuels, and therefore, do not maximize potential for long term growth;

3. These standards do not help to expand the energy resources (i.e. higher sulfur coal) that could be burned in compliance with emission limits as intended.

4. These standards aggravate compliance problems for existing coal burning stationary sources which cannot retrofit and which must compete with larger, new sources for low sulfur coal.

5. These standards increase the risk of early plant shut downs by existing plants (for the reasons stated above), with greater risk of unemployment.

6. These standards operate as a disincentive to the improvement of technology for new sources, since untreated fuels could be burned instead of using such new, more effective technology.

1976 HOUSE REPORT, supra note 115 , at 160.

129. The effect of percentage reduction requirements is to discourage the development of technologies that fail to meet specified levels of percentage reduction. Preclusion of new processes may occur even though the application of such technologies to lower sulfur fuels might produce reduced emissions at lower cost than the use of approved technologies on the high sulfur fuel that would otherwise be used. See generally Oversight: Effect of the Clean Air Act Amendments on New Energy Technologies and Resources: Hearings Before the Subcomm. on Fossil and Nuclear Energy Research, Development and Demonstration of the House Comm. on Science and Technology, 95th Cong., 2d Sess. 126.30 (1978) (statement of James L. Liversman, Dep't of Energy) (percentage reduction requirement may inhibit development of emerging technologies).

130. See, e.g., Clean Air Act Amendments of 1977: Hearings Before the Subcomm. on Environmental Pollution of the Senate Comm. on Environment and Public Works, 95th Cong., 1st Sess., pt. 2, at 90 (1977) (statement of James Laulis, member, West Virginia House of Delegates) (power plants should burn local coal) [hereinafter cited as Senate Hearings-1977 Amendments]. 
D.C. to accept the political invitation. Though controversies over existing plants and clean air regions predisposed public interest lawyers favorably toward the scrubber, leading environmental lawyers were aware of the heavy costs of imposing particular technologies on industry rather than permitting them to search out the cheapest way of meeting emission requirements. ${ }^{131}$ They also had a great deal of practice ferreting out assumptions buried in technocratic reports-it would not have been hard to flush out the EPA's false dichotomy between universal scrubbing and the preexisting 1.2 standard, which ignored cheaper alternatives for reducing emissions. ${ }^{132}$

Rather than explicitly campaigning for a congressionally mandated reduction in the 1.2 standard, however, public interest lawyers embraced the dirty coal rhetoric. For example, Joseph Brecher, on behalf of the Sierra Club, condemned the 1971 decision because "eastern high sulfur coal, which is now available, is having a hard time getting a market because of the comparative cheapness of bringing in western low sulfur coal."133 Richard Ayres, for the Natural Resources Defense Council, bemoaned the fact "that the Clean Air Act became a factor influencing the competition in the market for coal, encouraging practices such as shipping mountain state coal to Illinois and Louisiana, with attendant use of oil powering the diesel engines used to transport train after train of coal."134 Typically, environmentalists do not protest when a government initiative forces industry to discard "dirty" inputs and substitute "clean" ones. In so doing, government is simply eliminating market distortions and requiring the prices of high-polluting products to reflect their true social cost. ${ }^{135}$ Rather than condemning the advantage gained by clean coal as artificial, it is more characteristic

131. See Ayres, supra note 95, at 476 (agency development of technological expertise duplicates industry's activities, discourages innovation by industry, and distracts agency from environmental focus).

132. See p. 1496 supra.

133. EPA Public Hearing on Coal Fired Steam Generators SO $_{2}$ Emissions I-9 (EPA Docket No. OAQPS-78-I, Item No. II-G-2) (May 25, 1977); $i d$. at 47, 58-59 (Item No. IIG-3) (May 26, 1977) (statement of Nancy Bartlit, representing New Mexico Citizens for Clean Air and Water, Inc., and American Lung Association).

134. Senate Hearings-1977 Amendments, supra note 130, at 180, 209 (1977) (statement of Richard E. Ayres). Ayres continues to make explicit use of dirty coal rhetoric in the present controversy, now on appeal to the D.C. Circuit. See the revealing article by Ayres and Doniger, supra note 7 , at 78 .

In contrast to the suggestion made by Ayres in the text, it is now predicted that the free use of low sulfur coal instead of scrubbers will decrease the nation's dependence on oil. See ICF, Inc., The Final Set of Analyses of Alternative New Source Performance Standards for New Coal-Fired Plants 5 (June 1979) (prepared between December 1978 and May 1979).

135. Cf. A. KNEESE, R. Ayres, \& R. D'ARGe, supra note 69, at 2-15 (1970) (discussing problem of costs generated by high-polluting products). 
for environmentalists to applaud the fact that the "true" costs of dirty coal have finally been revealed. ${ }^{136}$ No matter. With such rhetorical assistance, the peculiar coalition between the friends of clean air and dirty coal would be a powerful political force.

Yet rhetoric alone cannot overcome the fundamental conflicts concealed by a marriage of convenience. While both groups wanted scrubbers, they wanted them for different reasons. Environmentalists saw scrubbing as a technique for cutting new plant emissions below 1.2 pounds to even lower levels. For example, if a plant using one pound Western coal was required to scrub at ninety percent efficiency, only 0.1 pound of sulfur oxide would be discharged. ${ }^{137}$ For Eastern coal interests, however, scrubbing was desirable only so long as new plants could keep discharging at the old 1.2 level. If the Administrator used scrubbing as a reason for lowering the standard dramatically below 1.2, this would, once again, freeze high sulfur coal producers out of the new plant market. ${ }^{138}$

We return, in short, to the master policy problem that the EPA had finessed in 1971 when it first established new source standards for coalburners. Given sulfur variability in coal, it is conceptually impossible to move unproblematically from the availability of scrubbing to the acceptable amount of $\mathrm{SO}_{2}$ coming out of the smokestack. Instead of focusing on technological means of purification, the critical question was whether the existing 1.2 ceiling was too high, too low, or about right. In 1971, the Administrator had resolved the low priority issue in a mechanical way. ${ }^{139}$ Now that the question was rising in prominence, the peculiar convergence between cledn air and dirty coal created a political situation in which the combine would avoid confronting the policy problem at all cost. Moreover, the House staff's drafting strategy made it easy for Congress to avoid a clear policy directive. By avoiding an explicit statutory amendment and manipulating legislative history, the House subcommittee could promise both political actors the best of both worlds. The House report stated that scrubbing would be required, ${ }^{140}$ eliminating utilities' incentive to burn low sulfur Western coal, and thereby satisfying Eastern coal interests. On the other hand, the Administrator remained free $e^{141}$ to use the new

136. See, e.g., Ayres, supra note 95, at 476 (qualified support of pollution tax to internalize costs).

137. Cf. Ayres \& Doniger, supra note 7, at 72-73 (table 1) (appropriate ceiling, based on $95 \%$ scrubbing, would be 0.17 pounds per MBTU).

138. See p. 1551 infra (discussing coal preclusion).

139. See p. 1485 supra.

140. See 1976 House REPORT, supra note 115 , at 161 .

141. Thus, the House report merely stated that the new NSPS must be at least as stringent as the old 1.2 standard. $I d$. 
technology as a reason for cutting back on overall emissions, thereby satisfying the environmentalists. But this time, when the Administrator was confronted with the decision, he would no longer be able to finesse the problem as he had in 1971. Instead, he would confront parties who thought that their political victories in the committee reports entitled them to legal victories in the administrative process.

\section{Avoiding Debate: 1976}

The premises underlying the "new" section 111 went largely unchallenged throughout the 1976 legislative process. The partisans of scrubbing had no incentive to enlarge the debate; high visibility discussion could only reveal the disparate hopes that bound the clean air-dirty coal coalition together. Because the utility industry concentrated its assault on PSD protection for "clean air areas,"142 no significant lobby invested resources in documenting the shaky relationship between universal scrubbing and any of the aims that Congress was considering. Moreover, the technocratic support work failed to signal the existence of a distinctive policy problem. The EPA study $y^{143}$ implied that the debate over universal scrubbing was a garden-variety environmental problem, involving a straightforward trade-off between higher costs and cleaner air. Nothing was said after the "new" section 111 left the House committee that reflected a general congressional awareness of the unnecessary expense, and the doubtful environmental benefit, generated by requiring nationwide scrubbing. ${ }^{144}$

The invisible revision in the language of section 111 passed through the House untouched; its relative lack of salience was emphasized by the fact that the Senate committee saw no need to include a comparable revision in its legislative proposals. ${ }^{145}$ When the conference

142. Interview with representative of Utility Air Regulatory Group, in New Haven, Conn. (October 22, 1979).

143. See pp. 1495-96 supra (discussing EPA Preliminary ANalysis, supra note 117).

144. At only one point in the committee's work was there any warning sign that universal scrubbing would not necessarily lead to cleaner air. See 1976 House REPORT, supra note 115, at 496-97 (comments of dissenting Congressmen arguing that requirement would impose unjustifiable burdens). This insight had no perceptible impact on the course of congressional debate.

145. The 1976 Senate bill, S. 3219, did require the use of "best available control technology" (BACT) as a part of PSD requirements for sources located in clean air regions. See S. REP. No. 717, 94th Cong., 2d Sess. 139, 158 (1976) (reprinting S. 3219). This BACT requirement, though, was keyed to the protection of clean air regions and did not require scrubbing on a national basis. Id. at 157 . Moreover, as originally conceived by the EPA, BACT merely required use of any control strategy sufficient to meet existing NSPS, including, for power plants, the use of either low sulfur coal or scrubbers. See 40 C.F.R. $\S \S 52.01(f), 52.21(\mathrm{~d})(2)(\mathrm{ii})(1976)$. Since the passage of the 1977 amendments, EPA has not 
committee reported out a compromise set of amendments, ${ }^{146}$ the House amendment to section 111-with its legislative history-was included without any further elaboration. ${ }^{147}$ At that point, however, the conference measure encountered determined opposition from Western industry and automakers. In response to a threatened filibuster, the Senate leadership shelved the controversy until the following session. ${ }^{148}$

\section{Midnight Lawmaking: The Problem of Agenda Overload}

In 1977, a new Congress and a new President still faced the need to amend the Clean Air Act. Unhappily, however, the "energy crisis" had replaced the "environmental crisis" as the central problem on President Carter's domestic agenda. In turn, this change in executive focus made it even more difficult for Congress to examine soberly the scrubber's relationship to basic environmental objectives.

\section{Energy Policy Takes Center Stage}

The President committed the executive's resources to James Schlesinger and assigned him the humbling task of devising a "comprehensive" energy plan in ninety days. ${ }^{149}$ In this context, scrubbing appeared once again as an ancillary concern. Independence from foreign oil could be purchased only by burning more domestic coal. Yet, to make coal burning politically acceptable, Schlesinger would have to come up with something that would calm environmental anxieties. Because the environmental lobby had proved to be a congressional power, scrubbing appeared an easy way to convert a dangerous opponent into a formidable ally. Not that Schlesinger was ignorant of the costs of scrubbing or the regional interests involved.150 But billions of dollars in costs ap-

treated BACT as requiring standards more stringent than NSPS, even where "demonstrated" technologies are capable of higher percentage reductions than those required by NSPS. See, e.g., EPA, Compilation of BACT/LAER Determinations 14, 16 (1979) (EPA Pub. No. 450/2-79-003).

146. In an effort to propose its own compromise, the Ford administration offered a proposal that accepted PSD in principle but delayed the BACT requirement until 1985. This proposal was quickly withdrawn, however, and had no effect on the evolution of the Act. See 7 ENvir. REP. (BNA) 532 (1976).

147. H.R. REP. No. 1742, 94th Cong., 2d Sess. 89 (1976) (conference report).

148. The conference compromise was dropped after a filibuster on the last day of the 1976 session. Major opposition came from the auto industry, as well as stationary source industries. See 7 ENvir. Rer. (BNA) 835 (1976).

149. For an informal analysis of the management process that produced the National Energy Plan, see N.Y. Times, Apr. 24, 1977, \$1, at 1, col. 1.

150. Schlesinger's staff produced a briefing paper that emphasized a few essential points. First, it made clear that a concern with clean air might be better expressed by reducing the present 1.2 emission level to some lower figure. Second, it revealed the regional economic conflict. Third, it emphasized that scrubbing "[w]ill raise utility capital requirements by $3-4 \%$ and electricity bills by $2-3 \%$." See 7 ENvIR. REP. (BNA) 1633 (1977) (summary of briefing paper). 
peared insignificant from the Olympian heights of comprehensive energy planning, especially when a simple solution to the environmental problem promised great political benefits. Universal scrubbing was therefore attached, as an environmental safeguard, to the steps in the energy plan that were intended to encourage utilities to increase their use of coal.151

Because scrubbing was now part of Schlesinger's comprehensive energy plan, it was no longer appropriate for the EPA, or anybody else in the executive, to ask hard questions about the relationship of scrubbing to any of the environmental goals before Congress in the 1977 clean air legislation. To the contrary, a carefully coordinated lobbying effort featuring, among others, Douglas Costle, the Administrator of the EPA, stressed the ways in which the President's plan was compatible with the legislation already pending before Congress. ${ }^{152}$ As a consequence, the House subcommittee had no incentive to reconsider its invisible change in the language of section 111, and the coal lobby rhetoric of the committee report remained essentially unchanged. Moreover, the new controls over new power plants were not the subject of a special vote in the House ${ }^{153}$ but passed as an undifferentiated part of the legislative package.

151. See Address Delivered Before a Joint Session of the Congress, 1 Pub. Papers 663 (Apr. 20, 1977); Address to the Nation, 1 Pub. Papers 656 (Apr. 18, 1977). The showpieces of the program were a series of taxes on consumers and producers of gasoline, some cautious steps toward deregulation of energy markets, and tax incentives and subsidies for energy conservation. See National Energy Program: Fact Sheet on the President's Program, 1 Pub. PAPERS 672, 674-87 (Apr. 20, 1977).

152. See, e.g., 1977 House Hearings, supra note 95, at 1677, 1678 (statement of Douglas Costle) (supporting use of high sulfur coal and BACT); Coal Conversion Legislation: Hearings Before the Subcomm. on Energy Production and Supply of the Senate Comm. on Energy and Natural Resources, 95th Cong., Ist Sess. 1392, 1393-94 (1977) (statement of Douglas Costle) (supporting BACT and PSD as mitigating effects of coal conversion); $i d$. at 1407, 1412 (statement of John F. O'Leary, Administrator, Federal Energy Administration) (supporting BACT as compatible with energy policy).

These statements revealed influence from above, not expert opinion below. By late 1976, EPA analysts had concluded that universal scrubbing was an environmentally unsound policy. See J. Crenshaw, D. Kirchgessner, H. Kuo, C. Miranda, \& A. Wehe, Staff Study: Alternatives for Revising the $\mathrm{SO}_{2}$ New Source Performance Standard for Coal-Fired Steam Generators at i, 33 (October 22, 1976) (EPA Docket No. OAQPS-78-I, Item No. IIA-7) (concluding that "[i]f the decision is made to revise the NSPS . ., then the most cost effective and advantageous approach would be to retain the form of the existing standard and to lower the allowable emission limit," and that "[t]he principal advantages of this approach [retention of a simple emission ceiling], other than cost considerations, are that it would reduce $\mathrm{SO}_{2}$ emissions most in the high sulfate region and that it would allow new plants latitude in determining how they will comply with the regulation.").

153. 33 Cong. Q. Almanac 78-H to 80-H (1977) (list of House roll call votes on Clean Air Act Amendments). 


\section{Regional Protectionism in the Open}

Although the scrubbing proposal hidden in the legislative history of section 111 gained no attention, a new initiative forced Congress, for the first time, to pay serious attention to the peculiar political logic behind forced scrubbing. The issue of regional protectionism was raised by the Act's treatment of old plants rather than new ones. Entitled "Measures to Prevent Economic Disruption or Unemployment," the new proposal evolved into section 125 of the Act. It permitted any Governor, the EPA Administrator, or the President to find that a shift from "Iocally or regionally available coal" would result in "significant local or regional economic disruption or unemployment."154 On such a finding, either the Governor or the President could order the source to use regional coal to meet the applicable emission requirement. ${ }^{155}$ Such an order, of course, would have the consequence of requiring a coalburner to install scrubbers to bail out local miners and mine owners. The amendment, which gained the explicit endorsement of the United Mine Workers, represented an enormous step in the evolution of the Clean Air Act. No longer was the Act's symbolic demand for the best technology made in the name of cleaning up the air; instead, the symbols of clean air were being manipulated in plain view on behalf of the coal-mining industry. Despite this fact, its last minute introduction on the House floor by Congressman Rogers, ${ }^{150}$ the floor manager, prompted no serious discussion. The proposal was adopted in an unrecorded vote. ${ }^{157}$

When, however, a nearly identical measure was introduced in the Senate by Senator Metzenbaum of Ohio, ${ }^{158}$ it precipitated the only thoughtful discussion of the implications of the clean air-dirty coal coalition. ${ }^{159}$ Senator Muskie, one of eleven speakers, noted that the amendment's "dominant thrust" was "not its relationship to clean air, but its relationship to the economics of the areas it is designed to protect."160 $\mathrm{He}$ warned against "regionalization" and announced his op-

154. Pub. L. No. 95-95, sec. 122, $\S 125(a), 91$ Stat. 685 (1977) (codified at 42 U.S.C. $\S$ 7425 (Supp. II 1978)).

155. In 1978, Congress further limited executive powers to issue regional coal use orders under $\S 125$, and removed the power of a Governor to initiate proceedings. Sec National Energy Conservation Policy Act of 1978, Pub. L. No. 95-619, $\$ 661,92$ Stat. 3206 (1978) (to be codified in 42 U.S.C. $\$ 6215$ ).

156. 123 Cong. Rec. H5026 (daily ed. May 25, 1977).

157. Id. at $\mathrm{H} 5027$.

158. Id. at $S 9449$ (daily ed. June 10, 1977) (amendment introduced on behalf of Sen. Metzenbaum (Ohio), Sen. Randolph (W. Va.), Sen. Bayh (Ind.), Sen. Heinz (Pa.)).

159. Id. at $\$ 9452-56$.

160. Id. at $\$ 9458$. 
position to the measure. In response, Senator Metzenbaum pointed to the support for the amendment expressed by the National Clean Air Coalition, the Environmental Policy Center, and the Sierra Club, "prestigious groups who have a concern with the whole question of clean air."161 Artfully, Metzenbaum beckoned his comrades to join hands with the National Clean Air Coalition in support of the fears of the United Mine Workers. ${ }^{102}$

Moving beyond its "natural" base of support in the Appalachian and Midwestern mining states, the amendment gained the support of just enough Eastern and Southern Democrats to offset Muskie's opposition, joined by the West, by a vote of 45 to $44 .{ }^{163}$ Minutes later, the Senate took a step to control the potential for mischief. Senator Domenici of New Mexico gained unanimous support for a proviso that was accepted without debate or roll call. ${ }^{164}$ Implicitly recognizing section 125 's status as special interest legislation, it stipulated that the Governor, the President, or the President's designee "shall take into account the final cost to the consumer" before invoking the section. ${ }^{165}$ This proviso made it clear that scrubbers should not be imposed if their cost was disproportionate to the protectionist benefits generated for local mines.

When put to a highly visible test, then, the clean air-dirty coal coalition could gain only an equivocal and highly qualified victory. Any market guarantee for dirty coal could be obtained only through a highly visible procedure in which decisionmakers found a causal link between pollution requirements and "significant local or regional economic disruption" and recognized the heavy costs to consumers that unnecessary scrubbing might entail. Because there was reason to expect a substantial increase in demand for Eastern coal over the next decade, ${ }^{106}$ it was plain that section 125 would, at best, provide limited areas with temporary relief-and even this was hardly guaranteed. Upon confronting the question squarely, the Senate gave the dirty coal-clean air lobby more symbol than substance.

\section{The Conference Compromise: Fabricating Legislative History}

In contrast, its treatment of the same issue under section 111 could not stand out in bolder relief. The only unambiguous benefit to be

161. Id.

162. Id.

163. Id. at $\$ 9459$.

164. Id. at S9468. Senator Muskie also supported the Domenici amendment. Id.

165. Id. (remarks of Sen. Domenici). See also Pub. L. No. 95-95, sec. 122, § 125, 91 Stat. 722 (1977) (codified at 42 U.S.C. $\$ 7425$ (Supp. II 1978)).

166. See, e.g., EPA PreLIMINARY ANaLYSIS, supra note 117, at V-5. 
gained by forcing all new plants to scrub, rather than use low sulfur coal, was the very same regional advantage that Senator Metzenbaum sought to procure. But here the future of scrubbing would not depend upon a high-visibility demonstration of economic dislocation in particular cases, but would be mandated on a nationwide basis at a cost of tens of billions of dollars. ${ }^{167}$ Yet, as the bill passed through the Senate, there was no easy way in which anxieties about the dirty coal-clean air coalition could express themselves in statutory form. For the Senate bill, like its 1976 predecessor, proposed no change in section 111,108 and the Senate report contained nothing resembling the House committee's low-visibility pronunciamento on behalf of dirty coal. However, the scrubbing lobby was more than content to evade explicit senatorial consideration by permitting history to repeat itself-leaving it to the conference committee to reach a "compromise" in which the House's legislative history would once again serve to expose the hidden meaning of section 111 .

The fate of the scrubber, then, was to be resolved as part of a final conference between House and Senate, charged with the task of hammering out a compromise on a host of issues more salient than the one raised under section 111-notably the future of auto emissions policy and the shape of the PSD amendments. ${ }^{160}$ The committee gave itself precious little time, perhaps adopting a Parkinsonian belief that political dealing would expand to fill the time allotted. Appointed in midJune, it did not meet until July 18,170 despite the House's announced intention to recess on August fifth. For the next hectic weeks, a changing cast of harried Congressmen and Senators and tired aides marked up the proposals before a ring of watchful lobbyists of all persuasions. The committee ended its deliberations at 2:20 a.m. on August third. ${ }^{171}$ Its final bill and report were typed on August third and approved by the House and Senate on the fourth in time for adjournment on the fifth. ${ }^{172}$

Once again, section 111 occupied its familiar position in the congressional twilight. By this time, however, the first few glimmers of awareness can be detected. George Freeman, a leading utility lobbyist, came to realize that the invisible amendment to section 111 might

167. For a fuller discussion of projected costs, see note 258 infra.

168. H.R. ReP. No. 564, 95th Cong., lst Sess. 130, reprinted in [1977] U.S. Code ConG. \& AD. NEws 1510 (conference report) (Senate did not change $\$ 111$ ) [hereinafter cited as 1977 CONFERENCE REPORT].

169. See 8 EnviR. REP. (BNA) 155-58 (1977).

170. Id. at 462 .

171. Id. at 509 .

172. Id. at 568; 123 Conc. Rec. H8672 (daily ed. Aug. 4, 1977); id. at S13,711. 
constitute a threat in its own right; but he had to devote his main efforts to PSD. ${ }^{173}$ Senator Domenici, having learned of the low-visibility House preference for scrubbing in the 1976 conference, was better prepared this time to question the new section $111.174 \mathrm{He}$ considered universal scrubbing, especially in the West, to be highly wasteful. Nonetheless, the House amendment to section 111 was not treated as an issue of the highest importance when the provision came up in the last week of the conference. When Domenici voiced his objections, the proposal was not made the center of a day's discussion-though even this would hardly do justice to the issue. Instead of this first class treatment, primary responsibility for section 111 was delegated to a handful of congressional aides whose principals had expressed concern.

Because the House committee had taken an institutional stand, the House staffers had the advantage of knowing the general position they were trying to advance. The situation on the Senate side posed a more complex problem. Even though Domenici was a Republican, his aide came to the bargaining session with substantial bargaining power, since the need to prevent a renewed filibuster made every vote important. But he could not press his views too far. The one thing the conference did not need was a major political confrontation on an issue that was generally considered of secondary importance. Also, Domenici did not have the solid support of his fellow Senators. Senator Randolph of West Virginia, a coal state, had declared himself in favor of the House amendment; the only real question was how hard he would fight for it. Although Senator Muskie had shown himself unsympathetic to Eastern coal interests in the vote on section 125, Domenici's aides were uncertain whether he would trade off a concession on section 111 for other issues he considered more important.

Within this general setting of political uncertainty, a small group of staffers tried to work out a compromise version of section 111. A series of legal uncertainties complicated their task yet further. Nobody could be quite sure what the House committee report would amount

173. Interview with representative of Utility Air Regulatory Group, in New Haven, Conn. (Oct. 22, 1979). For evidence of the utility industry's early uncertainty over the actual impact of the 1976 House amendment to $\$ 111$, see Senate Hearings-1977 Amendments, supra note 130 , at $289,296-98$ (analysis by George C. Freeman, Jr., discussing ambiguity of amendments to $\$ 111$ in 1976 conference bill).

174. The description of Senator Domenici's actions here and below is derived from interviews with aides to various senators and representatives on the House and Senate committees and the conference committee. Notes of interviews on file with Yale Law Journal. Prior to passage of the Senate bill on June 10, Senator Domenici submitted additional statements criticizing the House's revision of section 111. 123 CoNG. REc. S9477 (daily ed. June 10, 1977). 
to in the cold light of litigation. While Domenici's staff feared that the courts would give too much weight to the legislative history, the House staff wondered if it would succeed in using legislative history to inflate its minor changes in statutory language into a scrubbing requirement. Because section 111 would no longer float through conference unnoticed, they were not averse to raising their hidden agenda to statutory prominence. Yet, although both sides saw the merit of reworking the language of the House bill, an unambiguous statement of policy would precipitate the confrontation between their principals that all sought to avoid.

Senate staffers were successful in making one substantive point. A new subsection (h) made it clear that Congress did not want the Administrator to preempt the discharger's choice of the control technology that would best permit him to achieve emission limitations. Thus, unless it is "not feasible" to permit polluters to choose, the subsection denies the Administrator the authority to require a particular "design, equipment, work practice, or operational standard." The new definition of "not feasible," moreover, makes it plain that facilities like power plants cannot be subjected to design or equipment standards. ${ }^{175}$

Yet, while the Senate achieved this substantive prohibition, the House achieved a formal victory that looked in the opposite direction. Henceforth, the statute would require the Administrator to regulate power plants differently from other dischargers. ${ }^{176}$ Although the Administrator was to tell everybody else to reach a specified emission limit, an acceptable power plant standard also had to require

the achievement of a percentage reduction in the emissions from such category of sources from the emissions which would have resulted from the use of fuels which are not subject to treatment prior to combustion. ${ }^{177}$

175. Section $111(\mathrm{~h})(2)$ defines the phrase "not feasible to prescribe or enforce a standard of performance" to mean "any situation in which the Administrator determines that (A) a pollutant or pollutants cannot be emitted through a conveyance designed and constructed to emit or capture such pollutant . . . or (B) the application of measurement methodology to a particular class of sources is not practicable due to technological or economic limitations." Clean Air Act Amendments of 1977, $\S 109(\mathrm{a}), 42$ U.S.C. $\S 7411$ (h)(2) (Supp. II 1978). Power plants emitting pollutants through a smokestack equipped with continuous monitors clearly fall outside this definition. This definitional amendment was apparently intended to resolve the question raised in Adamo Wrecking Co. v. United States, 434 U.S. 275, 285-89 (1978) (Administrator's lack of authority to issue work practice requirements as standard of performance).

176. Section 111, as amended in 1977, distinguishes between fossil-fired stationary sources (primarily power plants and industrial boilers) and all other sources. Percentage reduction requirements apply only to sources in the former category. 42 U.S.C. $\$ 7411$ (a) (l)(A)(B) (Supp. II 1978).

177. 42 U.S.C. $\$ 7411$ (a)(I)(A)(ii) (Supp. II 1978). 
Henceforth, the Administrator must not only require a power plant to discharge no more than $\mathrm{X}$ pounds of sulfur oxide per MBTU, but also to reduce the sulfur in the coal by $\mathrm{Y}$ percent. By setting the percentage reduction requirement at a level only scrubbers could achieve, eightyfive percent for example, the Administrator could effectively force all coalburners to install scrubbers. But the statute falls far short of mandating such a high percentage. Indeed, it does not even require the Administrator to establish the same percentage for all coalburners. Although each plant must be assigned "a percentage reduction" to achieve, another subsection, unchanged from 1970, expressly authorizes the Administrator "to distinguish among classes, types, and sizes within categories of new sources for the purposes of establishing such [NSPS] standards."178 Hence, the Administrator has the authority to tell users of low sulfur coal to reduce their sulfur content by $Y_{1}$ percent and require high sulfur burners to eliminate $Y_{2}$ percent.

Indeed, when viewed within the framework of the section as a whole, the added provision does not even bar the Administrator from establishing a reduction of zero percent for low sulfur coal burners. For the new formal requirements are subject to the old substantive standard that requires the Administrator to consider "the cost of achieving . . . emission reduction[s]" before requiring the use of the "best technological system." 170 This provision explicitly makes cost a consideration before low sulfur users can be required to install scrubbers. Also, the statute's reference to the "best technological system" is not to be understood in its natural sense. It must be read in terms of the technical statutory definition, which includes "a technological process for ... operation by any source which is inherently low polluting or nonpolluting." 180 Although this expansive definition was introduced by the House staff in $1976,{ }^{181}$ the staff failed to modify it in the 1977 rush, even though it mocked their effort to prevent utilities from using "low polluting" varieties of low sulfur coal.

Rather than trying to bring the increasingly complex statutory language under control, the draftsmen turned to their first love: making legislative history. Once again, the House staff gained a victory in the conference report that it utterly failed to achieve on the surface of the statute: "The Senate concurs in the House provision with minor amendments. The agreement ... preclude[s] use of untreated

178. 42 U.S.C. § 7411(b)(2) (Supp. II 1978).

179. 42 U.S.C. $\$ 7411$ (a)(1) (Supp. II 1978).

180. 42 U.S.C. $\$ 7411(\mathrm{a})(7)$ (A) (Supp. II 1978).

181. See pp. 1494-95 supra. 
low sulfur coal alone as a means of compliance." ${ }^{182}$ Yet midnight legislative history is a game any number can play. Aides for Senator Domenici were quick to add their own opinion in the next paragraph: "the conferees agreed that the Administrator may, in his discretion, set a range of pollutant reduction that reflects varying fuel characteristics." 183 Given this threat, the House staffers counterattacked with another tack-on: "Any departure from the uniform national percentage reduction requirement, however, must be accompanied by a finding that such a departure does not undermine the basic purposes of the House provision and other provisions of the act, such as maximizing the use of locally available fuels." 184

These last remarks epitomize the abuses that follow from undisciplined legislative history. The only statutory recognition of Eastern coal interests is to be found in section 125, which does not seek to "maximize" local production but extends a highly qualified protection to areas suffering serious economic dislocation that can be demonstrably linked to pollution regulation. Rather than referring back to the coal lobby rhetoric contained in the old House committee report, an interpretation of the statutory language should refer to the aims of the statute declared in the Act itself-which, apart from section 125, shows no special solicitude for local coal producers. Just as the conference report fantasizes about the Act's basic purposes, its invocation of a "uniform national percentage reduction requirement" 185 is, as we have just shown, entirely unsupported by the language and structure of the statutory text. This extraordinary bit of legislative history can be understood only as an effort to offset the challenge raised by Senator Domenici's effort to "amend" the legislative history on his own behalf.

Apparently, the incoherent quality of the legislative history was apparent to the amendment's supporters almost immediately. After spending all of August third compiling the conference report that had been completed at 2:20 that morning, the staffers thought it wise to spend the next day formulating a "Clarifying Statement" while both Houses were voting their approval of the statutory language. ${ }^{186}$ Among these clarifications is one that reflects a continuing effort to wrestle with

182. H.R. ReP. No. 564, 95th Cong., 1st Sess. 130, reprinted in [1977] U.S. CodE CoNG. \& AD. NEwS 1510 [hereinafter cited as 1977 CONFERENCE REPORT].

183. Id. at 130, [1977] U.S. Code Cong. \& Ad. NEws at 1511.

184. Id.

185. Id. (emphasis added).

186. Clean Air Conference Report (1977): Statement of Intent; Clarification of Select Provisions, 123 Conc. Rec. H8662 (daily ed. Aug. 4, 1977), reprinted in [1977] U.S. CodE CONG. \& AD. NEwS 1570. 
the confusion. This time it is said that "while the conferees agreed that the Administrator may set the percentage reduction requirement as a percentage range, the conferees expect the Administrator to be exceedingly cautious if he should elect to do so. Such range would be allowed only to reflect varying fuel characteristics and must be based on a carefully and completely documented finding ... that [this] does not undermine the basic purpose[s] . . . of the House Report."187 But alas, the time had passed for putting such clarifications where they belonged-in the text of the statute itself.

In short, the draftsmen brewed a mix of statute and legislative history that was worthy of the occasion. Rather than integrating section 111 into the basic structure of the Act, their task was to avoid a potential conference impasse by writing a document whose legal meaning was hopelessly confused. The new section 111 is easier to understand as an exercise in small-group dynamics than as an effort to guide the bureaucratic management of a multibillion dollar problem.

\section{Beyond the New Deal: Congressional Performance}

Although we shall, in due course, ${ }^{188}$ speak in detail about the proper judicial interpretation of section 111 , our concerns with the congressional history go beyond this particular legal problem. For our story, we think, is rich with the symptoms of acute institutional breakdown that suggest more general lessons about the effort to move beyond the New Deal. On the one hand, our scrubbing story reveals a failure to discharge the functions Congress is uniquely equipped to handle in our system of government. On the other hand, Congress was entirely inept in discharging a function that could have readily been performed by an administrative agency.

Taking the first hand first, we understand Congress to be uniquely equipped to discharge two governmental tasks: first, the reconsideration of basic policy premises; second, the reflection of changes in predominant political opinion. Yet our long and complex story does not reveal any effort to discharge either of these functions. At no point did anyone use congressional reconsideration as a vehicle for ventilating the basic premises behind section 111. Was it sensible to divorce new plants from old plants in the way attempted by the 1970 Act? Were there innovative ways of regulating new plants that would be more satisfactory than "technology forcing"? Even if the answers to such questions

187. See id. at H8664, [1977] U.S. Code Cong. \& Ad. News at 1576.

188. See pp. 1556-66 infra. 
had amounted to nothing more than an endorsement of the status quo, the ensuing policy discussion might have yielded regulatory rewards in years to come. Instead of making this effort, however, the House staff never looked beyond the issues generated by litigation to define the problems of congressional concern. And even within these narrow boundaries, there was no inclination to think through the basic policy issue raised by new coalburners-whether the Administrator's 1.2 limit was too high or too low or just about right. Rather than refining the legislative definition of ends, it was necessary to avoid this question at all costs-lest it break apart the marriage of convenience between clean air and dirty coal.

Nor did congressional reconsideration of NSPS provide an occasion for reflecting a change in dominant political opinion about environmental regulation. To the contrary, the incoherent congressional revision of section 111 is a product of the special interests unleashedentirely unconsciously-by the artless way the NSPS statute was written in 1970. The effort to insulate technology forcing from New Deal ideals had succeeded only too well. Insulated from the corrosive questions of means-end rationality, the symbols of environmental purity had been appropriated by-of all people-the partisans of dirty coal. Indeed the success of the scrubbing lobby depended entirely on its ability to avoid a well-focused debate on the basic issues raised by the peculiar clean air-dirty coal coalition. As we have seen, the only section that explicitly linked scrubbing to the protection of high sulfur coal producers-section 125-squeaked through the Senate by a roll-call vote of 45 to 44 . Yet this highly qualified statute, in fact, promised very little economic relief to Eastern coal. ${ }^{189}$ Surely this vote did not augur well for a statute that would have required the expenditure of tens of billions ${ }^{190}$ on scrubbing so as to "maximize the use of locally available fuels." Such cheap talk could survive in the committee reports only so long as it did not provoke a political confrontation that would force the issue into the center of congressional consciousness. Rather than reflecting prevailing political opinion, section 111 could survive only by deflecting attention to other issues-PSD for the Congress, energy policy for the Carter administration.

Which leads us to the other hand. Rather than discharging its distinctive functions, Congress operated in this case as a peculiarly inept administrative agency, trying to resolve a disputable question of in-

189. See p. 1505 supra.

190. EPA, Preliminary Analysis, supra note 117, at V-8 (scrubbing on plants in attainment areas would cost additional $\$ 14$ to $\$ 16$ billion by 1990 ). 
strumental rationality without asking the most obvious questions raised by the scrubbing issue: What was so bad about sulfur oxide emissions anyway? Was forced scrubbing the cheapest way to solve the problem? Just how serious was the economic dislocation imposed by the shift to Western coal? Were there better ways of cushioning the blow to Eastern mines than spending billions on scrubbers? Rather than defining ends with care and articulating cost-effective policies to implement these goals, the final decision was made amongst a crush of conference committee compromises. Yet, while so much is obvious, we must move beyond these symptoms to more basic causes: how could the clean airdirty coal coalition induce Congress to act-albeit incoherently-on a multibillion dollar issue on such an inadequate foundation?

At least part of the answer, we think, can be found in the political economy of congressional attention..$^{191}$ Each subcommittee ${ }^{192}$ recognizes that the capacity of the full house to process issues is such a scarce resource that only the most salient questions will receive any serious attention from the great majority of representatives. As a consequence, each committee is in a position to manipulate the legislative process to achieve aims that would not survive if they were given clearly focused legislative attention. The problem is heightened by the proliferation of congressional staff over the past twenty years. ${ }^{193}$ Although these staffers do try to alert their Congressmen to important issues, their existence also makes it possible for strategically placed interest groups to generate many more low-visibility congressional initiatives. There is reason to fear that the demand for low-visibility legislation is outstripping the fixed supply of congressional attention. ${ }^{104}$

191. For some insightful general remarks, see R. DAHL, AFTER THE Revolution? $42-56$ (1970) (time as valuable and scarce resource).

192. See generally N. Polsby, Congress and the Presidency 110 (3d ed. 1976) (increasing autonomy of specialized subcommittees); Ornstein, Causes and Consequences of Congressional Change: Subcommittee Reforms in the House of Representatives, 1970-73, in CoNCRESS IN ChANGe 88, 105-110 (N. Ornstein ed. 1975) (reforms guaranteeing budgets, staff, and specific jurisdiction to subcommittees).

193. Between 1957 and 1976, staffing on congressional committees tripled, and Congressmen's personal staffs grew by $180 \%$. H. Fox \& S. Hammond, Congressional Staffs: The Invisible Force in American Lawmaking 171 (1977). Committee staffing grew by $81 \%$ between 1972 and 1976 alone. $I d$.

194. See generally Senate Committee System: Hearings Before the Temporary Select Committee to Study the Senate Committee System, 94th Cong., 2d Sess. 104 (1976) (statement of Sen. Morgan of N.C.) ("[A] great deal of the legislation in this Congress is initiated by staff," because Senators "just do not have the time to read the records and to do the necessary research that is necessary to bring forth meaningful and important legislation."); H. Fox \& S. Hammond, supra note 193, at 143-45. For a carefully documented discussion of the use and misuse of staff work by congressional subcommittees, see M. MALBIN, Unelected Representatives: Congressional StafF and the Future of Representative DEMOCRACY, ch. 5 (forthcoming 1980). 
Given this unhappy political economy, the case we have studied cannot be dismissed as aberrational. The fact that a low-visibility issue has not yet been subjected to hard-headed analysis can become a positive incentive for congressional action. So long as strategically located interest groups can provide superficially appealing symbols, they can hope that a single subcommittee's approval will not be challenged as the bill makes its way through Congress. This dynamic of agenda overload and symbolic subterfuge represents a challenge to all who wish to fashion a system of administrative law that represents a serious response to the admitted failures of the New Deal agency.

The second half of this essay builds on our case study in an effort to suggest more promising ways to move beyond the New Deal. Rather than resolving disputed questions of instrumental rationality, Congress should be encouraged, by all the legal tools at our disposal, to clarify the controversial ends of environmental policy. By the same token, the EPA should not be allowed to suppress controversial questions of instrumental rationality by casually invoking the well-worn myth of expertise. Instead, it should be induced to resolve inevitably controversial questions requiring expertise in high-visibility ways that constantly force bureaucrats to learn more about the complex areas they hope to regulate, and teach the rest of us of the costs and benefits of competing policies. At stake is a framework that supports a sounder institutional dialogue over time-one where Congress is obliged to reconsider values in light of emerging facts, and agencies are forced to clarify the costs and benefits of aims that captured the political imagination of earlier Congresses.

To put some flesh on these bare bones, we shall examine our particular problem from four interrelated points of view: First, what does a singleminded concern with instrumental rationality reveal about coal scrubbing and the larger issue of sulfur oxides of which it is a part? Second, how did the EPA, in fact, respond to the congressional initiative of 1977? Third, what questions should courts ask when called upon to review EPA decisions of the kind represented by the scrubber? And finally, what direction should Congress take the next time it is forced by events to reconsider the Glean Air Act?

\section{To What End?}

In the first half of this paper, we have shown how very different actors could come to view the scrubber as a plausible solution to their political problems. For Eastern coal, the scrubber secured markets 
against Western competition. For environmentalists, the scrubber promised to provide additional protection to pristine areas in the West. For the President, scrubbers promised political support for his high-priority energy program. For the conference committee, scrubbers were a nuisance that threatened to sabotage a long-delayed and vital agreement. All these interests converged to produce the legally incoherent message we have analyzed.

Yet, although political cost-benefit analysis explains the outcome, there is a second way of looking at the issue: What would universal scrubbing accomplish in reality? Are the benefits worth the costs? What are the alternatives? Although the New Deal agency often failed to answer these questions, at least it was expected to ask them. To pursue our interest in comparative institutional design, we shall look upon the scrubber as if it were a policy problem confronted by an ideal New Deal agency charged with the task of selecting the most sensible means to congressionally approved ends-protecting health and environmental quality by cleaning up the air. We do not seek to pass judgment on scientific questions now anxiously debated amongst researchers. Instead, we simply draw on the conventional wisdom now current in the EPA, ${ }^{195}$ to reproduce the way a knowledgeable EPA bureaucrat might analyze the problem if forced to argue in a means-end mode.

\section{A. Defining the Problem: Sulfur Oxides}

Begin, then, with the way current law defines the problem that scrubbing is meant to cure. When the federal government first set a health-related objective for sulfur oxides in $1969,{ }^{196}$ it was obliged to deal with the desperately primitive character of the prevailing "expert" understanding. Not only was data on real world conditions terribly inadequate, ${ }^{197}$ but the only available data measured concentrations of sulfur dioxide, although knowledgeable people recognized that $\mathrm{SO}_{2}$,

195. The regulatory scheme for emissions discharges by old sources is very much based on a New Deal effort to draft a policy responsive to environmental conditions. See pp. 1476.77 supra. Thus, in its efforts to deal with old sources, the EPA has gathered a great deal of data useful for means-end analysis.

196. See U.S. Def't of Health, Educ., \& Welfare, Air Quality Criteria for Sulfur Oxides (1969) [hereinafter cited as 1969 AIr QUALITY CRITERIA].

197. I U.S. Council on Environmental Quality, ANN. Rep. 87 (1970) (monitoring systems "so spotty in coverage that it is very difficult to determine trends in the quality of air"). Combined federal and state monitoring systems are now far more extensive, with data recorded by more than $2,600 \mathrm{SO}_{2}$ monitors and 4,000 TSP monitors, which are generally capable of measuring $\mathrm{SO}_{4}$ concentrations. Even today, though, the quality of data produced by many systems is poor. See General Accounting OfFice, RePort BY THE Comptroller General of the United States, Air Quality: Do We Really Know What Ir Is? 2, 5-17 (1979) (No. CED-79-4). 
taken by itself, was an inadequate measure of the pollution problem. ${ }^{198}$ Rather than the product of comprehensive study, the traditional emphasis on $\mathrm{SO}_{2}$ was a product of the famous "killer fogs" of London and Donora. ${ }^{199}$ In search of an explanation for these dramatic events of the 1940 s and 1950s, epidemiologists made use of available meters to isolate probable suspects. The monitors rewarded this search by revealing relatively high concentrations of $\mathrm{SO}_{2}$ and particulates in the air of suspect urban regions in the United States and Europe. ${ }^{200}$ As scientific activity increased in the 1970 s, however, evidence on $\mathrm{SO}_{2}$ typically generated no evidence of harmful effects. By 1978, the National Academy of Sciences could report: "The notion that ordinary concentrations of sulfur dioxide alone are not likely to injure the lung is commonplace." 201

198. See 1969 AIR QUALITY CrITERIA, supra note 196, at 118-19. Few experts ever attributed the known effects of air pollution solely to $\mathrm{SO}_{2}$. The air quality criteria document on which EPA's standard for $\mathrm{SO}_{2}$ is based explicitly stated its findings in terms of sulfur oxide and not $\mathrm{SO}_{2}$. The criteria document itself had to reserve the question of whether $\mathrm{SO}_{2}$ alone or other air-borne compounds actually caused observed effects, because in almost every observation, high levels of $\mathrm{SO}_{2}$ occurred in combination with high levels of other pollutants (typically particulate matter). This problem has continued to plague epidemiologists. Cf. Ferris, Health Effects of Exposure to Low Levels of Regulated Air Pollutants, 28 J. AIr Pollution Cont. Ass's 482, 491 (1978) (study finding health benefits over decade in which particulate levels decreased and sulfur oxide levels increased).

199. See 1969 AIr QUAITY CRITERIA, supra note 196, at 119-26. In the October 1948 Donora incident, 20 people died, $10 \%$ of the town's population was severely affected, and $43 \%$ was affected to some degree. The London fog in December 1952 resulted in 4,000 more deaths than would have been expected for the two-week period. Most deaths occurred among the elderly and persons with pre-existing pulmonary or cardiac problems. No pollutant monitors were present in Donora during the incident; a single monitoring site in London recorded extraordinarily high daily concentrations of $\mathrm{SO}_{2}$ and particulates. No measurements were made of particular species of particulates such as sulfates. Other episodes have occurred in the world's major cities since 1952, but none has been as serious. See Schimmel, Evidence for Possible Acute Health Effects of Ambient Air Pollution from Time Series Analysis: Methodological Questions and Some New Results Based on New York City Daily Mortality, 1963-1976, 54 BuLL. N.Y. ACAd. MEd. 1052, 1054 (1978).

200. 1969 AIr Quality CRiteria, supra note 196, at 120-24.

201. National Academy of Sciences, Sulfur Oxides 133, 166-71 (1978) [hereinafter cited without cross-reference as NAS, Sulfur OxIDEs]. See also Cooper \& Hamilton, Atmospheric Sulfates and Mortality-The Phantom Connection, reprinted in Oversight, OTA's Study: The Direct Use of Coal: Hearing Before the Subcomm. on Energy Development and Applications of the House Comm. on Science and Technology, 96th Cong., Ist Sess. 72, 79 (1979) (reporting respected experts' opinions that present $\mathrm{SO}_{2}$ standards are unduly stringent). Even when subjects were briefly exposed to laboratory concentrations thirty or more times the primary annual ambient standard, acute effects were only barely detectible. 1969 AIr QUALITY CRITERIA, supra note 196, at 91-94.

These results might be due to the fact that $\mathrm{SO}_{2}$, a gas, is sufficiently water soluble that it tends to be absorbed in the respiratory passages. It is unlikely that more than $10 \%$ of inhaled $\mathrm{SO}_{2}$, and even less of the $\mathrm{SO}_{3}$ breathed through the nose, penetrates as far as the larynx. NAS, SULFUR OXIDEs, at 134.

Still, some restrictions on peak levels of $\mathrm{SO}_{2}$ may be necessary. Laboratory tests of $\mathrm{SO}_{2}$ effects do not replicate ambient air conditions, and few tests have studied the effects of 
In contrast, recent research suggests that a major health hazard may be posed by sulfates $\left(\mathrm{SO}_{4}\right)$-compounds created by the interaction of sulfur oxides with sunlight and atmospheric particulates. ${ }^{202}$ As a result of this process, $\mathrm{SO}_{2}$ may be transformed over time into a number of potentially harmful sulfate compounds, including sulfuric acid.203 Although larger particles are blocked in the respiratory passage before reaching the lung, micron-size sulfate particles can elude these defenses and may be breathed deep into lung tissue..$^{204}$ The long-run harm, if any, caused by present concentrations of these tiny particles is far from clear, but the question is a central focus of present scientific concern. ${ }^{205}$

The EPA's regulatory program, however, has failed to advance with scientific understanding. The agency continues to measure polluter compliance in terms of $\mathrm{SO}_{2}$, not $\mathrm{SO}_{4}{ }^{206}$ Moreover, a shift in the relevant policy parameter would require a massive redefinition of the health problem posed by power plants. Although $\mathrm{SO}_{2}$ concentrations

pollutants in combination. Id. at 10 . Other pollutants might aggravate the effects of $\mathrm{SO}_{2}$. $I d$. at 153-55. Moreover, it is likely that at some point before ordinarily healthy people are affected, higher $\mathrm{SO}_{z}$ concentrations will begin to affect asthmatics and other sensitive groups. $I d$. at 158.

202. See note 205 infra (citing sources); NAS, Sulfur Oxides, at 196-99; Symposium on Environmental Effects of Sulfur Oxides and Related Particulates, 54 BuLl. N.Y. ACAd. MED. 983, 1052-199 (1978).

203. NAS, SULFUR OXIDES, at 150 .

204. Id. at 154-55, 158.60; see U.S. Council on ENvironmental QUality, supra note 1, at 58 .

205. Several recent epidemiological studies have established statistically significant associations between concentrations of sulfates and regional mortality rates. See, e.g., L. Lave \& E. Seskin, Air Pollution and Human Health (1977); Mendelsohn \& Orcutt, An Empirical Analysis of Air Pollution Dose-Response Curves, $6 \mathrm{~J}$. ENvT'L \& Econ. MANAGEMENT 85 (1979). Many epidemiologists question whether these new studies have adequately demonstrated that the observed effects are caused by the sulfates in the amounts measured. See, e.g., NAS, SULFUR OxIDEs, at 196-98 (assessment of Lave and Seskin); F. Lipfert, The Association of Human Mortality with Air Pollution 191-92, 196-97 (Ph.D. dissertation, Union Graduate School, Ohio, 1978) (analysis suggesting small but statistically significant association between mortality and general air pollution levels, but not between mortality and sulfates). One reason for doubt is that laboratory tests using human subjects exposed for short periods to sulfate concentrations below twenty times typical atmospheric concentrations have not shown adverse physiological reactions. See NAS, SULFUR OxIDEs, at 158.60. More generally, retrospective research of the sort carried out by Lave and Seskin cannot control for important confounding variables, such as variations in smoking habits among the populations studied. Therefore, many researchers evaluate the results as suggestive but inconclusive. See NAS, SuLFUR OXIDEs, at 196-98; F. Lipfert, supra, at $182-86$.

206. See 40 C.F.R. $\$ 50.4-5$ (1979) (national ambient air quality standards for SO.). Although the PSD system for clean air areas is occasionally a binding constraint as to the total amount of sulfur oxide produced by a plant, the program directly regulates only local concentrations of $\mathrm{SO}_{2} .42$ U.S.C. $\$ 7473$ (b) (Supp. II 1978). Although PSD may limit the amount of sulfur oxide emitted in or near protected clean air areas, it has its greatest impact on areas with the lowest levels of SO. EPA, Protecring Visibility 1-6(a) (1979) (EPA Pub. No. 450/5-79-008) (map depicting mandatory class I areas where least air quality deterioration permitted) [hereinafter cited as Protecring VisibILITY]. 
have declined dramatically over the past twenty years, ${ }^{207}$ limited data suggest that sulfate concentrations have remained constant or have increased slightly. ${ }^{208}$ Even more important, the following map dramatizes the uneven distribution of sulfates in the United States. The health threat, such as it may be, plainly concerns a twenty-odd state region east of the Mississippi and north of Tennessee and South Carolina. Average sulfate concentrations in rural areas in this region, which we shall call the "Northeast," are twice the typical level found in urban centers outside the Northeast.209

Within the Northeast, the typical city does not experience vastly higher sulfate concentrations than parts of the countryside. ${ }^{210}$ This pattern comes as no surprise, given the gradual way in which $\mathrm{SO}_{2}$ discharged from smokestacks combines with other atmospheric ingredients to form sulfates. Rather than imposing the primary sulfate burden on the immediately surrounding area, each power plant makes an incremental contribution to a regional sulfate problem, in inverse relation to its contribution to the local sulfur oxide problem. ${ }^{211}$ Quite simply, the more sulfur oxide that drops out within miles of the plant, the less

207. In the Northenst, composite urban average $\mathrm{SO}_{2 .}$ emissions declined from $88 \mu \mathrm{g} / \mathrm{m}^{3}$ in 1964 to $41 \mu \mathrm{g} / \mathrm{m}^{3}$ in 1971. EPA, The National Air Monitoring Program: Air Qusitity and Emissions Trends, ANNuAl Report 4-17 to -19 (1973) (EPA Pub. No. 450/1-73-001-a) [hereinafter cited as National Air Monitoring Program-1973]. Concentrations declined slightly between 1972 and 1977. EPA, NATional Air Quality, Monitoring, ANd Emissions TRENDS REPORT 3-8 (1978). These declines in $\mathrm{SO}_{3}$ concentrations occurred despite an estimated $45 \%$ increase in total nationwide emissions of $\mathrm{SO}_{2}$ between 1960 and 1970 , National Air Monitoring Program-1973, sufvra, at 4-3, illustrating the uncertain connection between air quality and absolute emission levels. The decline in concentration of $\mathrm{SO}_{2}$ is generally explained by reductions in residential and commercial coal burning in urban areas, increased stack heights, and increased geographical dispersion of sources. See NAS, SULFUR OXIDES, at 25.

208. Nonurban sulfate concentrations in the Northeastern United States have risen steadily since the early 1960s. NAS, SULFUR Oxides, at 21,25 (based on extremely limited data). In contrast, urban concentrations, at least in the few locations where they were monitored, declined sharply during the initial period of urban cleanup in the $1960 \mathrm{~s}$. For example, sulfate concentrations in New York City declined from about $33 \mu \mathrm{g} / \mathrm{m}^{3}$ in 1964 to about $13 \mu \mathrm{g} / \mathrm{m}^{3}$ in 1974. Eisenbud, Levels of Exposue to Sulfur Oxides and Parliculates in New York City and Their Sources, 54 BuLl. N.Y. Acid. Med. 991, 1003 (1978). Since 1970, however, urban sulfate levels, as measured by the National Air Surveillance Network (NASN), have remained generally constant, and nonurban levels have risen slightly, NAS, SULFUr OxidEs, at 25, even though total emissions declined slightly, EPA, Monrroring And Air Quality Trenus Report, 1974, at 125-26 (1976) (EPA Pub. No. 450/1-76-00I) (1970 to 1974 estimates).

209. EPA, Air Quility for Nonmetallic INokginic Ions, 1971 through 1974: From the National Air Survilleance Networks 55-70 (1977) (during periodic episodes of air stagnation when sulfate levels greatly increase, concentrations in Northeast are also higher than in other regions).

210. Id.

211. EPA, Sulfates in the Atmosphere: A Progress RIport on Projict Mist 18.25 (1977) (EPA Pub. No. 600/7-77-921); NAS, SUlFur Oxides, at 50-56 (describing modes of $\mathrm{SO}_{2}$ deposition). 


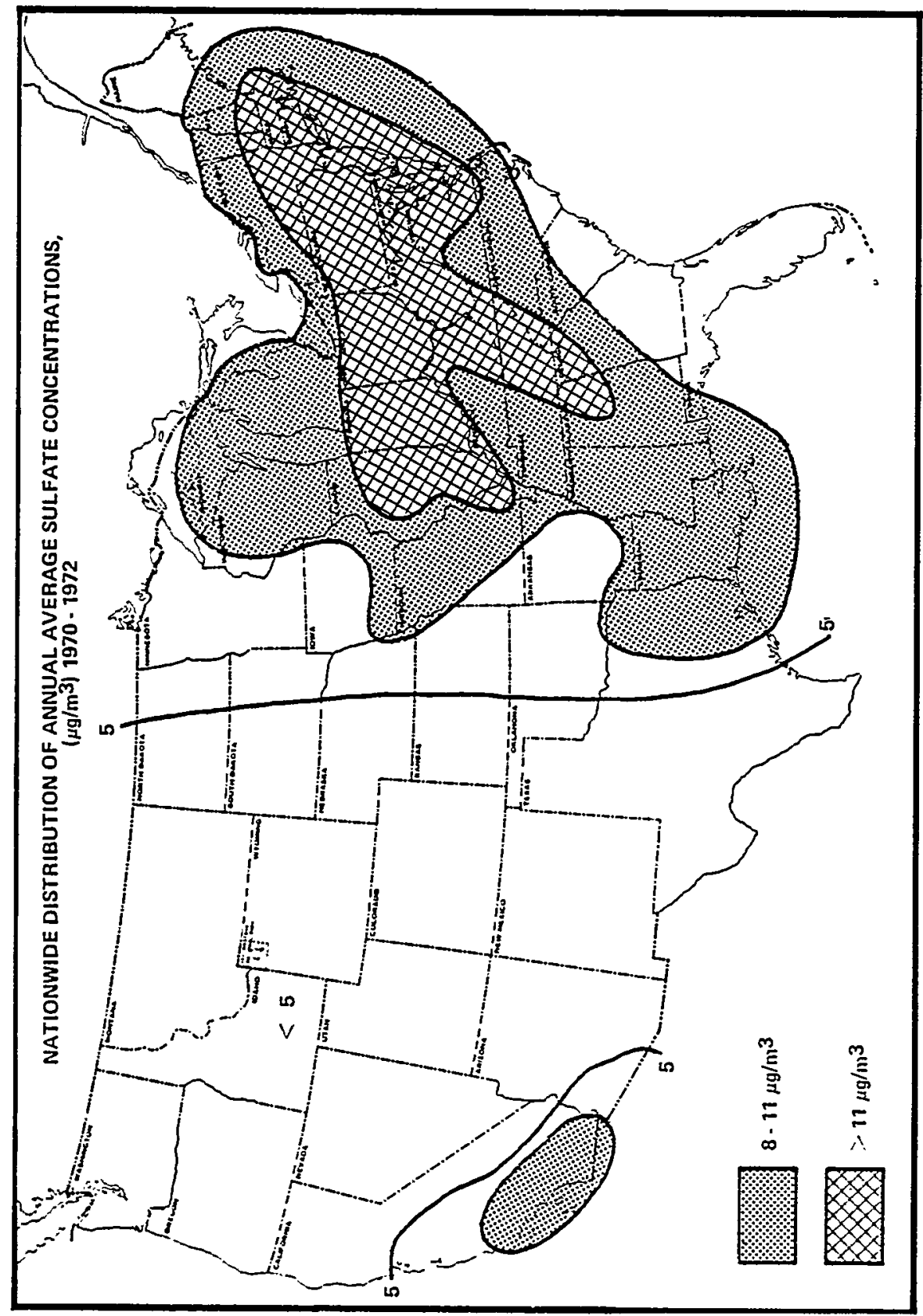

Reprinted with permission of authors from: N. Frank \& N. Possiel, Seasonality and Regional Trends in Atmospheric Sulfates (paper presented at American Chemical Society, San Francisco, Cal., Aug. 30-Sept. 3, 1976) (figure 2) 
that remains for gradual transformation into sulfates over longer distances. ${ }^{212}$ Moreover, each plant's impact on the health of people hundreds of miles away depends upon a variety of geographic and meteorological conditions. ${ }^{213}$

At this point, one can begin to glimpse the opportunity lost when the parties began to focus upon technological means (the scrubber) rather than ultimate ends (public health). Imagine that in the face of these evolving "facts," a New Deal agency had tried to justify billions of dollars of scrubbing by pointing to the clear and present danger to health posed by sulfur dioxide alone. Such a move, predictably, would have been reversed as "arbitrary or capricious" by any court of appeals in the land. ${ }^{214}$ Indeed, as a result of the dramatic decline in $\mathrm{SO}_{2}$ since the early sixties, even the most "polluted" areas only rarely register violations of the EPA's $\mathrm{SO}_{2}$ standard. ${ }^{215}$

Not that these facts would, by themselves, destroy the environmentalists' love affair with the scrubber. But if forced to pursue their ends in a New Deal decisional structure, they would have selected a very different argumentative strategy. To make the New Deal case for the scrubber, it would be essential to attack, on all fronts, the EPA's continuing fixation with $\mathrm{SO}_{2}$ and to point with alarm to $\mathrm{SO}_{4}$ as the real danger. ${ }^{210}$ For it is only then that a multibillion dollar effort to reduce sulfur discharges yet further would seem at all plausible. This external attack would have met with great sympathy amongst the

212. See EPA, supra note 211, at 24-25; NAS, SULFUR OXIDEs, at $41-49$ (describing transformation process).

213. NAS, Sulfur OXIDEs, at 37-40.

214. Many scientists have stated that there is no need to tighten present ambient $\mathrm{SO}_{2}$ standards. Cooper \& Hamilton, supra note 201, at 79 (standards probably too stringent); Ferris, supra note 198, at 493-94 (standards "reasonable"); see NAS, SULFur OxIDES, at 166. New plants meeting the pre-1977 NSPS would generally not cause increases sufficient to violate the regional ambient $\mathrm{SO}_{2}$ standards, unless they were situated in close proximity to existing emission sources. See $1978 \mathrm{SO}_{2}$ Background InFormation, supra note 65, at 6-12 (percentage of ambient limits contributed by different sizes of power plants).

215. In $1974,3 \%$ of the monitoring stations recorded violations of the primary ambient standard of $80 \mu \mathrm{g} / \mathrm{m}^{3}$, in contrast to $16 \%$ in 1970 . NAS, Sulfur Oxides, at 24. The most serious problems today occur in areas affected by smelters, U.S. Council on ENvironMENTAL QualitY, supra note 1 , at 45 , which are free to obtain postponements for compliance with $\mathrm{SO}_{2}$ standards. 42 U.S.C. $\$ 7419$ (Supp. II 1978).

216. To their very great credit, environmentalists have indeed sought to force the EPA to promulgate a sulfate standard under sections 108 and 109. Although the EPA has, predictably, resisted this effort, see Sierra Club v. Train, No. 76.0656 (D.D.C., filed Apr. 20, 1976; dismissed with prejudice, Jan. 19, 1978) (attempt to force promulgation of sulfate standard), it would be a mistake to think of the EPA as if it were some immovable object incapable of adaptation under stress. If the enormous amount of environmental energy devoted to the scrubbing controversy had been channelled toward the sulfate problem, it is quite possible that bureaucratic inertia might have been mastered. 
scientifically trained agency staff, who are perfectly aware of the changing direction of expert understanding.

Challenged from without and prodded from within, high-level administrators might have been induced to take the hard steps required to redirect regulatory activity. At present, the EPA divides the country into 236 air quality control regions, ${ }^{217}$ each of which is responsible for forcing local polluters to meet local ambient standards. A rational approach to $\mathrm{SO}_{4}$, in contrast, would require dividing the country into a smaller number of larger regions to take into account the realities of long-distance transport. Any such change would encounter strong bureaucratic resistance; yet, because the debate was shifted from the EPA to Congress, no one perceived, let alone emphasized, the need for overcoming this resistance. Although there is evidence of congressional staff awareness of the emerging sulfate problem, ${ }^{218}$ the clean air-dirty coal coalition had everything to lose, and nothing to gain, from a sober analysis of ecological realities. Rather than directing congressional attention to the need for a regional response to protect the East, the sulfate menace was used as a makeweight in the rhetorical case for forced scrubbing.

\section{B. Protecting Health and Environment in the East: The Perils of Scrubbing}

Assume, next, that our hypothetical New Deal agency has managed to redirect its policy objective from $\mathrm{SO}_{2}$ to $\mathrm{SO}_{4}$ in line with prevailing scientific opinion. How would it go about appraising the threat posed by sulfates?

Although the impact of sulfates on humans remains uncertain, there is little question of their harmful impact on some non-human species. As a result of increased sulfur and nitrogen emissions, $\mathrm{pH}$ levels in rainwater have noticeably declined over the last several decades. ${ }^{210}$ Long-distance transport from the Midwest and East creates the most acute effects in northern New York, New England, and eastern Canada. ${ }^{20}$ In freshwater lakes that serve as collectors of acid rain and stormwater runoff, increased acidity has eliminated many fish

217. 40 C.F.R. $\$ \S 81.12-.267$ (1979) (defining air quality control regions).

218. The legislative history of the 1977 amendments provides evidence of this congressional concern in its consideration of a number of the Act's new sections. See, e.g., H.R. REp. No. 294, 95th Cong., Ist Sess. 191 (1977) (NSPS); id. at 122-24 (PSD); id. at 83-84 (ICS); cf. 42 U.S.C. $\$ 7423$ (Supp. II 1978) (limit to stack heights). For a good history of the public debate concerning sulfates, see $R$. Tobin, The Social Gamble: Determining Acceptable Levels of Air Quality 127-56 (1979).

219. NAS, SULfur OxIDEs, at 52-54.

220. See id. at 65 (reporting measured increase in acidity of lakes). 
species.221 The effects of acid rain are most pronounced in those geological regions where the characteristic rock types are highly resistant to weathering, with the result that acids are not effectively neutralized before reaching the lake ecosystems. ${ }^{222}$ Many ecologists suspect that acid rain has the capacity to affect significantly the structure and function of terrestrial ecosystems as well, possibly resulting in reduced timber and agricultural production.223 However, given the spatial and temporal variability in these systems, anything short of dramatic environmental consequences will be difficult to detect.224 There is cause for concern, and room for further research. ${ }^{225}$

The primary task, however, is to fashion an action program that responds sensibly to the dangers we perceive and allows us to define these risks with increasing precision over time. How does a scrubbing requirement for new plants fit into these larger ends?

\section{Short-Term Action}

A sensible short-term strategy for the Northeast must focus, first and foremost, on old plants, not new ones. For the foreseeable future, the bulk of sulfur oxides in the Northeast will be produced by presently existing plants. ${ }^{206}$ Moreover, SIPs often permit old plants to emit four or five pounds of sulfur per MBTU, ${ }^{227}$ while the old NSPS held new plants to a 1.2 pound per MBTU ceiling. It is hardly apparent that

221. Id. at 70-71.

222. Likens, Wright, Gelloway, \& Butler, Acid fiain, Scientific AMerican, Oct. 1974, at $43,49-50$.

223. See, e.g., NAS, Sulfur Oxides, at 80-82, 112-115; Likens \& Bormann, Acid Rain: $A$ Serious Regional Environmental Problem, 184 SCIEnCE 1176, 1178 (1974).

224. NAS, SUlfur OXIDEs, at 80-81, 112-15.

225. Recent legislation provides up to $\$ 50$ million for a ten-year study of acid rain. Acid Precipitation Act of 1980, Pub. L. No. 96-294, 94 Stat. 770 (to be codified at 42 U.S.C. $\$ \S 8901-8905$ ).

226. Although some debate exists, many scientists now believe that much of the sulfate concentration in the Northeast originates in the Midwest. (This article uses the term "Midwestern" to describe power plants in the Bureau of the Census' East North Central region (Ohio, Indiana, Illinois, Michigan, and Wisconsin).) See, e.g., U.S. DEP'T of Energy, Regional Issue Identification and Assessment: First Annual Report 1-10, 2-8, 3-7 (1979) (modelling results predicting that sulfur oxides transported from Midwest significantly affect $\mathrm{SO}_{4}$ concentrations in New England, New York, and mid-Atlantic areas); Wolff \& Lioy, Transport of Suspended Particulate Matter into the New York Metropolitan Area, 54 Buld. N.Y. AcAd. Med. 1032-44 (1978) (suggesting that transport of SO, from Midwest associated with certain weather patterns significantly increases $\mathrm{SO}_{4}$ levels in New York City area); General Discussion: Session I, 54 Bulc. N.Y. Acad. MEd. 1045-51 (1978) (defense of Wolff \& Lioy, supra, by one of its authors). Even if all Midwestern plants subject to the new (1979) NSPS were allowed to emit at 1.2 pounds per MBTU, these plants would emit only $11 \%$ of the sulfur oxides produced by utilities in the Midwest in 1995. ICF, INC., supra note 134, at C-II-3a. Overall, in 1995, new plants emitting $\mathrm{SO}_{2}$ at a rate of 1.2 pounds per MBTU would produce $28 \%$ of the sulfur oxides produced by utilities east of the Mississippi. Id. at C-II-3a to $-3 \mathrm{~b}$.

227. See note 40 supra. 
short-term cutbacks could be purchased most cheaply by making relatively clean new plants even cleaner. Unfortunately, however, the Clean Air Amendments of 1970 discouraged knowledgeable analysis of this trade-off between old and new plants; with old plants regulated through the New Dealish SIP process and new plants by an agencyforcing Congress, there was no forum in which the trade-off question might be considered as a part of the ordinary course of business.

Nonetheless, such an expert comparison would yield large rewards. Although old plants can often achieve reductions by installing control equipment, important gains may also be obtained by washing sulfur pyrites from pulverized coal at the mine site. Although washing does not remove sulfur organically bonded to the coal, modern methods do remove twenty to forty percent of the total sulfur content of coal currently mined in high sulfur Eastern regions. 228 At present, however, a leading EPA expert estimates that only forty percent of Eastern coal is washed before it is burned,220 and EPA consultants estimate that universal washing could reduce present Eastern emissions by more than two million tons a year. ${ }^{230}$

Moreover, the marginal cost of achieving this emission reduction seems far lower than anything attainable by forcing new plants to scrub. According to a leading EPA expert, the cost of washing high sulfur coals ranges from two to nine cents a pound of $\mathrm{SO}_{2}$ removed, compared to a cost range of seven to forty-five cents a pound for a ninety percent scrubbing system. ${ }^{231}$ If the present sulfate threat jus-

228. See J. Kilgroe \& J. Strauss, supra note 55, at 2, 10 (table 3).

229. See J. Kilgroe, Coal Cleaning for Sulfur Oxide Emission Control 20 (Apr. 8-9, 1980) (unpublished paper presented at Acid Rain Conference, Springfield, Va.) (on file with lale Law Journal).

230. Estimates by Versar, Inc. (May 1980) (supplied to the authors by EPA) (on file with lale Law Journal). Versar reports that a reduction of 2.8 million tons a year is achicrable by washing all cleanable steam coals mined in 1976 in major Eastern and Midwestern coal producing states. Because American utilities consumed $78 \%$ of available supplies of nonmetallurgical (steam) coal in 1976, 2 U.S. ENERGY INFORMATION AwMIN., AnN. Rep. To Congress 91-93 (1978), 2.2 million tons of this reduction may be assigned to utilities. Because utilities classified as existing sources will consume roughly as much coal in 1995 as in 1975, ICF, INC., supra note 134, at C-II-5, the same reduction from cxisting plants can be achieved at least as late as that year.

231. J. Kilgroe \& J. Strauss, supra note 55, at 22-23. Note the wide range in marginal costs prevailing under both scrubbing and washing. Large scrubbers have low marginal costs, thanks to cconomies of scale. Id. at 23. Scrubbing costs also vary with changes in sulfur content and degree of scrubbing. See note 233 infra. Washing high sulfur coal is cheaper than washing lower sulfur varieties, J. Kilgroe \& J. Strauss, supra note 55, at 22, because increased costs involved in crushing and separating pyritic sulfur are not proportional to increases in the sulfur content of the coal. Thus, washing $30 \%$ out of a nine pound coal could generate three times the sulfur reduction achieved by washing $30 \%$ out of a three pound coal without proportional increases in cost. Indeed, the Kilgroe and Strauss estimates seem to understate washing's relative cost advantage. As they explain, washing coal increases boiler reliability, decreases maintenance, and reduces the cost of fly ash removal. These non-environmental benefits reduce the net cost of the technology. 
tifies a serious short-term response, it is the less costly method-washing-that should be employed first.

All the more so because increased coal washing in existing plants will bring sizable $\mathrm{SO}_{2}$ reductions far sooner than scrubbing in new plants. Students of coal washing think it realistic to believe that at least a " 1 to 2 million" ton reduction is achievable by 1985.232 In contrast, facilities regulated by the new NSPS will begin to come on line in the late eighties, and forced scrubbing in the East will not achieve a remotely comparable impact upon the overall $\mathrm{SO}_{2}$ load before the midnineties. Worse yet, by adding up to fifteen percent to the cost of new construction, ${ }^{233}$ forced scrubbing will give utilities an economic incentive to run their old plants longer than they otherwise would. Because old plants are often permitted to emit four or five pounds of $\mathrm{SO}_{2}$ per MBTU, one old plant produces as much $\mathrm{SO}_{2}$ as three or four new ones subject to a 1.2 ceiling. Thus, even if a relatively small fraction of old plants are induced to stay on line for an extended period, the overall impact could be quite serious. Indeed, in the industrial Midwest, the old-plant effect swamps the extra reductions achieved by forcing all. new plants to scrub-causing the Midwest to impose 170,000 more tons on the Northeast in 1995 than it would have under the old 1.2 NSPS. ${ }^{234}$ The old-plant effect is not so strong in other parts of the East. As a consequence, forced scrubbing does yield a net reduction east of the Mississippi by 1995 of slightly less than one million tons, compared to the old 1.2 standard. ${ }^{235}$ This is to be compared to the " 1 to 2 million" tons promised by washing in 1985 .

Id. at 26 (table 5), 27. In contrast, scrubbing generates no similar savings in ordinary plant operation.

Although Kilgroe and Strauss' optimistic assessment of coal washing seems generally supported by the studies they cite, there are studies that suggest a smaller cost advantage in favor of washing. For example, a recent TVA study suggests that the average cost of scrubbing at $85 \%$ is only slightly greater than washing at about $35 \%$. See J. Kilgroe, supra note 229, at 24-26. Kilgroe, however, does not reconcile this study's conclusions with the work that supports the cost comparison cited in the text. More generally, the data base on washing costs seems weak-reflecting the low institutional priority given the question until very recently. Similarly, the second-order environmental effects of disposing of waste products generated by various washing and scrubbing systems deserves more focused study than it has received. Finally, the cost estimates presented here ignore the savings attainable by substituting lower sulfur coals for treatment technologies.

232. J. Kilgroe, supra note 229, at 22; see id. at 28 (3 to 5 years to put coal cleaning plant into operation). At least one EPA consultant estimates a potential reduction exceeding two million tons a year. See Estimates by Versar, Inc., supra note 230.

233. See EPA, Cost Analysis of Lime-Based Flue Gas Desulfurization Systems for New 500-MW Utility BoILERs 4-24 to 4-32 (1979) (EPA Pub. No. 450/5-79-003) (estimates by PEDCo Environmental, Inc.) The cost of a scrubber for a given plant varies with the sulfur content of the fuel burned and the degree of scrubbing required.

234. ICF, INC., supra note 134, at C-VIII-21.

235. Id. (960,000 tons). This figure may overstate relief to the Northeast because it includes reductions in several Southeastern states, whose contribution to the Northeast's 
Coal washing, then, seems the short-term strategy of choice: it promises bigger gains sooner and more cheaply. How sad, then, that thanks to our effort to move beyond the New Deal, our policy has evolved in just the opposite direction. While policymakers rushed toward scrubbing in new plants during the late seventies, they allowed the SIP process to remain focused upon the attainment of local $\mathrm{SO}_{2}$, rather than regional $\mathrm{SO}_{4}$, air quality goals. As a consequence, old coalburners have been permitted to keep on burning unwashed coal so long as their locality satisfied their $\mathrm{SO}_{2}$ target. An expert agency concerned with a cost-effective response to the emerging sulfate problem would have made the opposite choice.

Suppose, next, that our hypothetical agency concluded that the near-term sulfate problem was so serious that it demanded that the Northeast's present load $^{236}$ be quickly reduced by more than the "1 to 2 million" tons generated by increased coal washing. Even on this policy assumption, however, forcing all new plants to install scrubbers would seem a silly way to achieve greater cutbacks. Rather than imposing a high technology requirement on the utility industry, the goal should be to force utility executives to seek out the cheapest way of achieving further cutbacks. If reductions can be achieved more cheaply by altering the operation of old plants or by buying low sulfur coal, then it is these strategies that should be pursued. Moreover, the regulatory tools necessary to encourage utilities to search for the cheapest control measures are now very familiar in the pollution control literature. ${ }^{237} \mathrm{~A}$ host of market-like schemes have been proposed to force polluters to recognize the social costs of their emissions and take efficient steps to control further discharges. Under these systems, the burden of designing a cost-effective response is placed where it belongs-on the polluters themselves, not on some government bureaucrat.

sulfate problem is unclear. Moreover, before 1995, full scrubbing promises even smaller gains. The EPA's consultants predict that, in 1990, a $90 \%$ scrubbing requirement will generate an extra reduction of only 390,000 tons east of the Mississippi. $I d$. at C-VIII-21.

236. In 1975, power plants emitted 16.0 million tons of $\mathrm{SO}_{2}$ east of the Mississippi. Id. at C-II-3a to -3b. This, once again, includes emissions from the Southeast. See note 235 supra.

237. See W. Baumol \& W. OAtes, Economics, Environmental Policy, and the Quality of Life 209-369 (1979); Fisher \& Peterson, The Environment in Economics: $A$ Survey, 14 J. Econ. Literature 1, 12-14 (1976). For the reasons discussed in B. Ackerman, S. RoseAckerman, J. Sawyer, \& D. Henderson, The Uncertain Search for Environmental QUALITY 260-81 (1974), we favor a system allowing the sale of pollution rights to the highest bidder over an effluent tax. In particular, it is easy to modify the auction system to take into account the fact that new plants need to buy rights for longer periods of time than old plants require. See id. at 268. 
Even if, however, an agency rejected such cost-effective regulatory systems and imposed a special emission ceiling on new plant emissions, forced scrubbing is plainly inferior to other regulatory strategies. Rather than requiring the installation of scrubbers, it would be far more sensible to reduce the emission ceiling required of new plants. Assume, for example, that the ceiling had previously been set at 1.2 pounds per MBTU. Then it is easy to imagine cases in which the addition of a requirement that polluters scrub ninety percent of the sulfur out of their coal yields absolutely no emission reduction. If cheap high sulfur coal is readily available, cost-minimizing utilities may continue to discharge 1.2 pounds per MBTU and simply substitute higher sulfur coal for the more expensive low sulfur varieties they might otherwise burn. In contrast, lowering the 1.2 ceiling guarantees lower emissions from new plants while inviting utility executives to define the cheapest way of meeting the new target. Given this contrast, no agency concerned with the cost-effective pursuit of clean air would have any trouble preferring a lower ceiling to forced scrubbing as a regulatory option.

Finally, forced scrubbing suffers a low-visibility disadvantage when compared to strategies that permit polluters to meet their obligations the natural way by burning low sulfur coal. Quite simply, a universal scrubbing requirement threatens to overwhelm the existing enforcement system; if this occurs, a symbolically satisfying gesture will serve to cloak a very different reality. Once a scrubber is installed in a new plant, a utility will be free to buy high sulfur coal on the expectation that it will be scrubbed down to the 1.2 requirement. ${ }^{238}$ If, however, the scrubber fails to operate, all the sulfur will go out the smokestack. The greater the efficiency demanded of the scrubber, the greater the pressure placed on the enforcement system. If the EPA requires ninety percent scrubbing, and a utility achieves only eighty percent, the plant's emissions will be twice the legal limit. 239

The only way to assure serious compliance is through constant dayto-day oversight. If utility executives are quickly placed on notice of

238. EPA models predict that the great majority of coal burned in Midwestern plants subject to mandatory scrubbing would have a sulfur content betwcen 3.3 pounds and 5.0 pounds, ICF, INc., supra note 134 , at C-VIII-8a to -8b. Without forced scrubbing, $69 \%$ of Midwestern plants are predicted to burn coal that naturally emits less than 1.2 pounds of $\mathrm{SO}_{2}$. Id. at C-II-8b to $-8 \mathrm{c}$ (remaining plants predicted, for economic reasons, to use high sulfur coal with scrubbing).

239. Scrubbing at $90 \%$ removal efficiency allows the release of $10 \%$ of the $\mathrm{SO}_{2}$ original$1 y$ in the flue gas; $80 \%$ removal allows the release of $20 \%$-or twice the legal amount. 
equipment failures as they arise, it is not too unrealistic to expect good faith efforts to obey the law. ${ }^{240}$ But constant oversight requires a reliable monitor in each smokestack, recording and reporting day-today operations. These monitors are being developed, but their durability and day-to-day reliability remain to be established. ${ }^{241}$ In addition, the EPA and state agencies must analyze the data promptly and dispatch trained inspectors to conduct spot checks when excess emissions are detected. Whenever a meter registers a potential violation, there are always two possibilities-either the scrubber, or the meter, is malfunctioning. Some official must then personally determine what is actually going on in the smokestack.

There is every reason to believe, however, that the EPA and the states do not intend to organize the necessary enforcement effort. Today, inspection visits are few and far between; usually, the EPA has only unverified data from polluters themselves, and much of it is never entered into EPA computers for analysis. ${ }^{242}$ As a result, the EPA has recently found that many systems thought to be in compliance are in fact violating present requirements. ${ }^{243}$ Nonetheless, the bureaucracy intends to continue to rely on the polluters themselves to supply data on their scrubbing efficiency. ${ }^{244}$ This means that the regulators will

240. To the extent that current operating problems experienced by scrubbers result mainly from insufficient attention to the design and operation of control technology, $c f$. note 243 infra (improper design and operation of control equipment found to be major source of excess emissions), simple good faith efforts might represent a significant advance over current practices. The EPA has long asserted that proper operation could significantly reduce the problems experienced by scrubbers. See generally FGD System CaPAbILITIEs, supra note 56 , at 4-2 to 4-14.

241. See Entropy Environmentalists, Inc., An Evaluation of the Continuous Monitorinc Requirements of the SePtember 19, 1978 SubPart Da NSPS Proposal 33-38 (1979) (reporting 1978 studies showing monitors available for use only $51 \%$ to $57 \%$ of period studied). The cited authority was submitted to the EPA docket on behalf of the utility industry, but relies in part on earlier studies done by Entropy Environmentalists for the EPA. I $d$. at 33-35. The EPA now generally agrees with Entropy's analysis of monitor reliability, and in its 1979 NSPS decision revised its proposed monitoring requirements in an attempt to take monitor outages into account. See 44 Fed. Reg. 33,580, $33,610(1979)$.

242. See General Accounting Office, Report by the Comptroller General of the United States: Improvements Needed in Controlling Major Air Pollution Sources 7-8, $11-13$ (1979) (No. CED-78-165).

243. See Complying Power Plants Exceed Air Limits by 25 Percent, Drayton Tells Chamber, 11 ENvir. REP. (BNA) 5 (1980) (reporting 71\% of "complying" sources studied experienced incidents of excess emissions; excess emissions from plants not in compliance averaged $25 \%$ of amount allowed by emission standards). The EPA attributes roughly two-thirds of the excess emissions to either improper design or improper operation of pollution control equipment. Interview with analyst, EPA Planning Office, in Washington, D.C. (June 25, 1980).

244. See 40 C.F.R. $\$ \S 60.47$ a -.49 a (1979) (monitoring and reporting requirements for 1979 NSPS). Direct responsibility for the enforcement of NSPS may belong to either the 
be unable to distinguish reliable from unreliable information; and without credible information, the threat of sanction is incredible.

Absent constant enforcement pressure, it will be all too easy for the scrubbing operation to serve as the public utility industry's Siberia-a place where employees unfit for moneymaking tasks are sent when it is inconvenient to fire them. The threat posed by incompetent or lackadaisical employees is especially serious when it is recognized that their tasks will not be restricted to mechanical maintenance operations. Scrubbers will constantly be demanding creative tending when they become clogged, corroded, or generally ornery. ${ }^{245}$ A conscientious, highly competent staff is an absolute requirement. ${ }^{246}$ Given corporate incentives to place scrubbing on the backburner, it is especially important for the agency to create an administrative infrastructure equal to the challenge of enforcement. ${ }^{247}$ Otherwise, the result will be a lot of junk in the smokestack and a lot more sulfur in the air.

In contrast, a strategy emphasizing the use of low sulfur coals places far smaller burdens on the enforcement system. Meeting the 1.2 standard the natural way means that there is no need to monitor complex machinery on a daily basis. All that is required is a regular sampling of the sulfur content of coal going into the plant, rather than the smoke coming out of the smokestack. Although even this may be beyond the present effort forthcoming in many areas, it does not seem too much to hope that officials may, from time to time, be able to collect chunklets of coal for laboratory analysis. ${ }^{248}$ When the realities of enforcement are taken into account, low sulfur strategies seem even more attractive than they appear in ordinary cost-benefit analysis.

EPA or to state enforcement agencies, depending on whether or not the EPA delegates its own authority. See 42 U.S.C. $\$ 7414$ (b) (Supp. II 1978) (authority to delegate enforcement duties to states). The effectiveness of state enforcement systems varies widely. General Accounting Office, supta note 242, at 8-9.

245. See FGD SYSTEM CAPABILITIES, supra note 56, at 4-2 to 4-9.

246. See M. Maxwell, Sulfur Oxides Control Technology in Japan at 21, 23-24 (Interagency Task Force Report, June 30, 1978) (attributing successful operation of scrubbers in Japan in part to careful operation and special training of staff); REPORT OF THE HEARING PANEL, supra note 49 , at 29 (suggestion that American utilities have failed to hire sufficient qualified personnel).

247. Commentators have attributed the successful use of scrubbers in Japan to the strength of the Japanese enforcement program. The Japanese operate central research centers, which are usually linked directly via telemetry to stations monitoring emissions from major sources. M. Maxwell, supra note 246 , at 24 .

248. Although the enforcement problem is far more tractable under a low sulfur strategy, it still exists. Even coal from the same mine may vary substantially in sulfur content. For a discussion of regulatory problems created by sulfur variability, see Memorandum from Walter C. Barber, Director, Office of Air Quality, Planning and Standards, EPA, to Barbara Blum, Deputy Administrator, EPA (Dec. 6, 1979), reprinted in 10 ENVIR. REP. (BNA) 1872, 1873 (1980). 


\section{Long-Term Responsibilities}

But what about a cleaner tomorrow? Don't we owe something to the Easterners who will be breathing the air in the year 2000?

Certainly. ${ }^{249}$ But once this is granted, the question of instrumental rationality remains to be asked: What steps should we take today on behalf of the Easterners of the next generation?

Beginning, once again, with the obvious, we do not now know enough about how sulfates of different kinds and quantities harm us. $^{250}$ There is still much to be learned about what quantities there are of each type, ${ }^{251}$ where the particles are produced, and how they are transformed during long-distance transport. ${ }^{252}$ A generously funded, long-term research operation is needed to fill the large gaps in our knowledge. ${ }^{253}$ Yet the EPA is planning to spend only fifteen million dollars a year on its Sulfur Research Strategy for fiscal years 1980 to 1982, and only nine million dollars in $1983,{ }^{254}$ at a time when future consumers are being asked to spend three or four billion dollars a year on behalf of universal scrubbing. ${ }^{255}$ This is a disgraceful failure to respond to the true interests of the next generation. Long-term research provides the only way we shall ever clarify the health risks generated by alternative energy sources. Surely we owe this to our children, whatever measures we take in the short term. An adequate research budget should be at least ten times its present fifteen million dollars. Even at this price, it would cost no more than three medium-sized scrubbers. ${ }^{250}$

Although research is a first priority, we must also confront the fact that plants built today will last until the year 2020. It hardly follows, however, that immediate scrubbing is the best way to take account of this fact. If the EPA maintained the 1.2 ceiling and merely required present-day designers to plan for possible scrubber retrofits, the marginal cost of adding scrubbers at a later date would be relatively

249. See B. Ackerman, Social Justice in the Liberal State 111-13, 202-17 (1980).

250. NAS, Sulfur OxudE, at 180-204. See also Ferris, supra note 198, at 493-94.

251. NAS, SULFur OXIDEs, at 40-41.

252. Id. at $41-51$.

253. See Stationary Source Emission Control, supra note 43, at 148; Rall, Review of the Health Effects of Sulfur Oxides, 8 EnvT'L HeAlth Perspectives 97, 117 (1974) (plan for distinguishing effects of various pollutants). For a discussion of research policy that points in the same direction, see $R$. ToBIN, supra note 218, at 160-64.

254. EPA, Sur.fates Research Aprroach 3 (1977) (EPA Pub. No. 600/8-77-004). The Department of Energy and the Electric Power Research Institute also spend significant amounts on research on sulfur oxides.

255. See p. 1541 infra.

256. See ICF, Inc., Still Further Analyses of Alternative New Source Performance Standards for New Coal-Fired Powerplants B.15 (Jan. 1979) (prepared between September and December 1978) (estimating cost of scrubber for $500-\mathrm{MW}$ plant at $\$ 56$ million). 
small. ${ }^{257}$ It thus makes eminent sense to avoid the short-term environmental dangers posed by a universal scrubbing requirement and leave it to the next generation to make up its own mind about its future. With high interest rates, the loss caused by wasteful current investment ${ }^{258}$ will be especially great. Twenty years from now, moreover, technology may have moved far beyond the scrubber in its search for clean air. ${ }^{259}$ At the very least, it will be possible to retrofit spanking new 2010 scrubbers into 1990 plants, rather than rely on creaky museum pieces. Why, then, act now?

Perhaps such a hasty, ignorant, and costly step might be morally required if a failure to scrub imposed risks on the next generation far greater than those that we ourselves must accept. The best available predictions, however, suggest that no such reckless disregard of posterity is in question here. Even if we retain the "old" NSPS, EPA models suggest that overall $\mathrm{SO}_{2}$ loads in the East will be no higher in 2010 than they are today. ${ }^{260}$ Although the number of coalburners will increase, the replacement of 4-pound old plants by 1.2 pound new plants will completely offset the effects of increased coal use. Thus, even without scrubbing, we are not ruthlessly sacrificing the interest of the next generation to the convenience of this one. To the contrary, scrubbing not only is a costly way of providing the next generation with museum pieces, but will expose present-day Midwesterners to greater harm than they would otherwise suffer.

Instead of relying on technological symbols, the task is to direct bureaucratic energy toward building ecologically sophisticated structures for sulfate control. The process of controlling sulfates should begin long before any smokestacks are built. As we have seen, ${ }^{201}$ the

257. No formal studies on the costs of planned retrofit exist. An engineer active in the field of scrubber research expressed confidence, in an interview, that so long as space is provided for potential retrofitting, the extra costs of later installation will be relatively modest.

258. The new EPA standard will require $\$ 26$ billion more in capital costs for scrubbers by 1990 than the 19711.2 standard, which allowed utilities to use untreated low sulfur coal or to scrub at a percentage less than 90\%. ICF, ING., supra note 256, at C-IV-19.

259. Both government and private industry are currently engaged in research to improve sulfur removal technologies. See generally Gage, Remarks, in FGD SYMPosium, supra note 56, at 2, 3-7; Laseke \& Devitt, Status of Flue Gas Desulfurization Systems in the United States, in FGD SYMPosium, supra note 56, at 22, 43-49; Morasky \& Dalton, EPRI's Flue Gas Desulfurization Program, Results, and Current Work, in FGD SYMposium, supra note 56, at 96, 96-117. Indeed, EPA officials are already expressing optimism over the development of new, improved technologies that are readily retrofittable. See EPA Says New Technology May Provide Much Cheaper Sulfur Dioxide Removal, 11 ENvIR. REP. (BNA) 63-64 (1980) (development of "exciting" new technology that can be retrofitted for $20 \%$ of present cost of scrubber retrofit).

260. See ICF, ING., supra note 134, at C-II-3a to -3b, D-1a (SO.z emissions east of the Mississippi predicted to decline from 16.0 million tons in 1975 to 13.1 million tons in 2010 ).

261. See pp. 1518-20 supra. 
same discharge of $\mathrm{SO}_{2}$ can generate very different amounts of sulfate in very different places depending on a host of geographic and meteorological conditions. Hence a critical part of sulfate planning comes in judicious site selection-the more $\mathrm{SO}_{2}$ that settles in nearby unpopulated areas, the less that remains for long-range transport in the form of sulfates. If, for example, a power plant can be sited in unpopulated hill country, this would go a long way toward reducing its impact on regional health. ${ }^{262}$

Even after a site is selected, the design of the plant will influence its sulfate contribution. For example, the higher the smokestack, the lower will be nearby $\mathrm{SO}_{2}$ readings, but the greater the plant's load of longrange $\mathrm{SO}_{4} \cdot{ }^{263}$ Although, as we have noted, ${ }^{264}$ conventional wisdom now belittles the effect of low-level concentrations of $\mathrm{SO}_{2}$, nonetheless there is a point where higher concentrations will begin to affect asthmatics and other sensitive groups. ${ }^{205}$ Rather than looking exclusively at the scrubber in the smokestack, an intelligent long-range plan must try to define the extent to which the size of smokestacks can be reduced in the name of sulfate control without imposing unacceptable pollution levels near the plant. ${ }^{266}$

Finally, a bit of long-range planning may greatly ease the chronic enforcement problem afflicting present-day control efforts. When a utility decides to build a new plant, it either builds a "captive" mine or contracts for a guaranteed long-run supply. ${ }^{267}$ It is at this pointyears before the first coal is burned-that enforcement agents may in-

262. On the broadest inter-regional level, prevailing meteorological patterns may cause some areas of the nation to be more desirable sites for power plants than others. See Ball \& Matheny, Impediments to Air Quality Control: The Problem of Long Range Transport (Proceedings, Institute of Environmental Science) (n.d.) (figure 4) (ton of sulfur dioxide produced in heavily industrialized areas of Midwest may expose two to five times as many people to given concentration of sulfate as same amount emitted in most areas of New England). It may be possible to locate plants so that the bulk of their sulfate loadings descend on unpopulated areas, or even the Atlantic Ocean.

In some areas, such as New England, relatively short distances separate sites with relatively large differences in population exposure. For an excellent study of control alternatives in one metropolitan area, on a plant-by-plant basis, see R. Mendelsohn, Towards Efficient Regulation of Air Pollution From Coal-Fired Power Plants 138-60, 177 (1978) (concluding that siting considerations minimize cost of abatement on local level under certain conditions).

263. See EPA, supra note 211, at 24-25.

264. See p. 1516 \& n.201 supra.

265. NAS, SuLFur OxIDEs, at 158 .

266. Decreasing stack height will also increase local concentrations of other pollutants produced by power plants, such as nitrogen oxides and particulates. The relative effect of increased levels of these pollutants, must, of course, also be considered. $\mathrm{Cf}$. Rall, supra note 253, at 117-18 (advocating research strategy designed to determine relative importance of various pollutants by selectively altering pollutant concentrations).

267. U.S. Dep't of ENergy, Federal Energy Regulatory Comm'N, Status of Coal Supply Contracts for New Electric Generating Units: 1977-1986 at 3 (Supp. 1978). 
tervene. To the extent possible, steps should be taken to assure that the "captive" mine site will yield coal that will uniformly satisfy the Clean Air Act's requirements. ${ }^{268}$ Such steps should ameliorate, if not solve, the problem posed by plants receiving shipments of coal that vary greatly in sulfur concentration.

The next generation, then, will have just cause for resentment if we fail to resist the urge to scrub. Rather than leaving our children some odd museum pieces scattered in the smokestacks of the year 2000, we might have handed them a far worthier inheritance: a deeper understanding of the risks involved in coal burning; a subtle mechanism for siting and designing plants to do the least harm; a mechanism for limiting the risks of inevitable enforcement lapses. With such help from the present, the future would be in a position to take care of itself far better than we can protect ourselves today.

\section{Beyond the East: The Problem of Visibility}

While the Northeast is the critical problem area for health and acid rain, ${ }^{269}$ a final problem requires a shift of geographic focus to the West. The same discharge of sulfur oxide will have a vastly different impact on visibility ${ }^{270}$ depending on the background level of lightextinguishing particles in the air. As particles are added to pure air, visibility declines at an exponential rate. ${ }^{271}$ Thus, where visibility is already impaired by the particle-producing activities of an urbanized and humid region like the Northeast, the marginal impact of power

268. Due to the effects of sulfur variability on the regulation of power plants, see Memorandum from Walter C. Barber to Barbara Blum, supra note 248, EPA has recently begun extensive work on the problems of predicting both the long- and short-term average sulfur content of known coal reserves. See J. Kilgroe \&: J. Strauss, supra note 55, at 21-22 (citing sources). Given the size of America's coal reserves, such work is only beginning. Nonetheless, some progress is being made. For example, it now appears that, where variability is a problem, coal cleaning may not only reduce average sulfur content, but its associated variability as well.

269. In the foreseeable future, sulfate levels west of the Mississippi will not approach prevailing Eastern levels. See p. 1519 supra (sulfate distribution map). We should not worry about the health of Westerners until the risk to Easterners has been reduced to Western levels.

270. The most commonly discussed aspect of visibility is visual range. Visual range is usually defined as the distance at which a typical observer, under daytime conditions, can distinguish a target on the horizon with a visual contrast of $2 \%$ (the theoretical contrast limit of the human eye). Experimental data have suggested, however, that the typical human eye may not detect contrasts smaller than 5\%. 2 A. STERN, AIr Poliution 14, 17-18 (3d ed. 1977); see W. Middleton, Vision Through the Atmosphere 92-95 (1952). The uncertainty introduced by this and other choices of assumptions used in empirical studies is substantial. See note 272 infra. Nevertheless, a $2 \%$ limit for "standard" observers is com. monly assumed by researchers. See Protecting Visibility, supra note 206, at 8-10.

271. 2 A. STERN, supra note 270 , at $5.9,14$. 
plants on visibility is relatively small. In contrast, if particles are introduced into pure air, ${ }^{272}$ even slight increases in emissions may have highly visible effects.273 Although no area is completely particle-free, the Rocky Mountain states and the Southwest do enjoy large areas of extraordinary visibility, ${ }^{274}$ which may suffer perceptible impairment if particle concentrations are increased.

Power plants may pose two different threats to Western visibility, requiring different methods of control. On the one hand, each plant contributes to the overall level of "background" particles throughout a large region surrounding the plant-the background problem. On the other hand, each plant has a more concentrated impact on the narrow strip of territory downwind from its stack-the plume effect. ${ }^{275}$

Turning first to the plume, the visibility problem posed by sulfur oxides is not a matter of belching smokestacks. $\mathrm{SO}_{2}$, the only sulfur oxide emitted directly by power plants, is a colorless gas. ${ }^{276} \mathrm{Visibility}$ is impaired by the slow and long-distance transformation of gaseous $\mathrm{SO}_{2}$ into $\mathrm{SO}_{4}$ particles. Thus, the plume has a perceptible impact on visibility only when it remains concentrated long enough for substantial $\mathrm{SO}_{4}$ formation to occur. ${ }^{277}$

For an ideal New Deal agency, the first step in mitigating the plume effect would be to shift enforcement efforts from average $\mathrm{SO}_{2}$ levels measured over long periods ${ }^{278}$ to the concentration of $\mathrm{SO}_{2}$ on the days

272. Maximum visual range, in air completely free of particles, is approximately 200 miles assuming the human eye has a $2 \%$ contrast limit, see note 270 supra, or approximately 150 miles if the contrast limit is 5\%. See Protecting Visibirity, supra note 206, at 2-18, 2-23 (calculations based on equation therein; calculations disregard complications produced by curvature of earth). In pure air, visibility is impaired only by "blue sky" or Rayleigh scattering-the scattering of light produced by "air" molecules themselves. 2 A. StenN, supra note 270 , at 5.

273. At 8 miles of visibility, typical in urban areas in the East, an increase of $4 \mu \mathrm{g} / \mathrm{m}^{3}$ in sulfate levels will reduce visual range by less than half a mile. In contrast, if the air were perfectly particle-free, the same sulfate concentration would reduce visibility by half, from about 200 to 100 miles. (Calculations based on assumption that each $\mu \mathrm{g} / \mathrm{m}^{3}$ of $\mathrm{SO}_{4}$ increases the visual scattering coefficient by $0.04 \times 10^{-1} \mathrm{~m}^{-1} / \mu \mathrm{g} / \mathrm{m}^{3}$.)

274. The EPA presently estimates median visibility in the Southwest to be 65 to 80 miles at most sites away from large urban centers, with visibility at nonurban locations extending to 90 to 115 miles $10 \%$ of the time. EPA, VISIBILITy IN THE Southwest: AN Exploration of the Historical Data Base 37 (1978) (EPA Pub. No. 600/3-78-039) [hereinafter cited as VISIBILITY IN THE Southwest].

275. See generally Protecting VisibiLITY, supra note 206, at 5-1 to 5-4.

276. IX ENCYClopedia BRITANnica 661 (15th ed. 1974). The smoke seen pouring out of the stack is composed of water vapor, nitrogen oxides, and particulates.

277. See Protecting Visibility, supra note 206, at 5-10 to 5-11. Other pollutantsespecially nitrogen oxides-probably produce far more noticeable plume effects than sulfur oxides within 30 miles of the plant. $I d$. at $5-11$ to -13 .

278. Current enforcement is based on figures for annual average discharges. Memorandum from Walter C. Barber to Barbara Blum, supra note 248. The EPA proposes to enforce emission limitations for NSPS using monthly averages. 40 C.F.R. $\$ 60.43 a(c)$ (1979). 
when meteorological conditions permit the plume to retain its integrity for substantial periods of time for distances of fifty to a hundred miles. ${ }^{279}$ Rather than spending billions to scrub tenths of pounds out of low sulfur coal, it makes more sense to spend millions on a beefed-up enforcement system that assures day-to-day compliance with visibility objectives. ${ }^{280}$ In addition, a rational policy for preserving visibility would establish varying ceilings for plants of different sizes. The overall quantity of $\mathrm{SO}_{2}$, not the amount of $\mathrm{SO}_{2}$ per MBTU, determines the size of the plume. A 2000-megawatt plant limited by a 0.6 pound per MBTU ceiling creates the same plume effect as a 1000-megawatt plant regulated by a 1.2 pound per MBTU ceiling.

Moving beyond present polluters, we need guidelines for building new plants. The height of their smokestacks will affect the concentration of $\mathrm{SO}_{4}$ and visibility hundreds of miles away. ${ }^{281}$ Moreover, tradeoffs between nearby $\mathrm{SO}_{2}$ and distant $\mathrm{SO}_{4}$ pose even fewer dangers here than in the East. Because Western power plants are often located in remote regions, they can use short stacks to enhance visibility without health effects. Finally, better scientific models are urgently required to predict a future plant's plume effect. ${ }^{282}$ Such modeling, in conjunction with study of the meterological conditions at particular potential sites, may reveal sites where plumes will diffuse with minimum impact on protected "clean air regions" or populated areas.

After a plume disperses, it adds to the "background" $\mathrm{SO}_{4}$ level over a large region. In some parts of the West, particularly Arizona, diffused emissions from a few large smelters have perceptible effects on visibility over large areas, ${ }^{283}$ even though background levels, by Eastern standards, remain low. More generally, Western smelters produce several

279. See Protecting VisibiLIty, supra note 206, at 5-18 (significant reduction in visibility possible at distances in excess of 100 miles).

280. Even intermittent controls may be desirable if enforceable. The EPA in the past prepared regulations for intermittent controls that were tentatively endorsed by the National Academy of Sciences. See Stationary Source Emission Contror, supra note 43 , at 216.

281. EPA, supra note 211, at 24-25; Protecting VISIBILITY, supra note 206, at 2-36 to -38.

282. Models used for the consumption of PSD increments merely predict $\mathrm{SO}_{2}$ concentrations to a distance of 30 miles. Interview with a representative of EPA Office of Air Quality, Planning and Standards, in Research Triangle Park, N.C. (June 9, 1980). The impact of SO, on visibility occurs only at 50 or more miles from the plant. Protecring VIsiBILITY, supra note 206, at 5-11. Models for predicting plume effects at these distances have yet to overcome a number of technical problems, and regional-scale models have yet to be validated. $I d$. at 5-20 to -24 .

283. During a nine-month copper strike which closed Western smelters, sulfate levels in Arizona dropped by $60 \%$ to $67 \%$, and visibility improved across the state by $8 \%$ to $29 \%$. See VisibILITY in THE SouthWest, supra note 274 , at 88-89, 92-93. 
times the amount of $\mathrm{SO}_{2}$ generated by the region's power plants. ${ }^{284}$ Hence, the small incremental reductions obtained by full scrubbing will have little effect on regional emissions of $\mathrm{SO}_{2}$ for the next generation. ${ }^{285}$ Conversely, the EPA predicts that, even with less than full $\mathrm{SO}_{2}$ control, visibility in the region will improve by $1995^{286}$ if smelters institute statutorily mandated emission reductions. ${ }^{287}$ Thirty years from now, power plants will play a larger role in the overall $\mathrm{SO}_{4}$ picture in the Southwest and greater concern may prove justified. ${ }^{288}$ Therefore, it may make sense to impose a retrofit design requirement. ${ }^{289}$ At present, however, the background problem cannot rationally justify billions of dollars of scrubbing, especially when the smelting industry is permitted, thanks to another 1977 amendment, to delay compliance until the year 1988, and may succeed in deferring compliance to an even later date. ${ }^{290}$

Finally, we must devote more resources to research on the basic facts concerning visibility. ${ }^{291}$ We are not even confident, at present, of the basic equation that purports to explain how far the eye can see in a pollution-free world. ${ }^{292}$ And it is plain that visibility is a complex psychological-aesthetic concept that must be measured with great sensitivity in a number of different locations. ${ }^{293}$ Scrubbing cannot substitute for this complex work.

So far as the West is concerned, scrubbing is an exceedingly expensive way of achieving minor reductions in $\mathrm{SO}_{4} ;{ }^{204}$ in the East,

284. In 1976, smelters in the eight-state Rocky Mountain region emitted 2,484,000 tons of $\mathrm{SO}_{3}$, versus 430,000 tons emitted by power plants. EPA, 1976 NationaL EMissions Report 15, 40, 78, 187, 198, 211, 318, 360 (1979) (EPA Pub. No. 450/4-79-019).

285. See Memorandum from John Bachmann, Air Office, to Walter C. Barber, Air Office (Mar. 7, 1979) (EPA Docket No. OAQPS-78-I, Item No. II-B-37) (figure 1, table 1) (difference in emissions between partial and full scrubbing equal to 300,000 tons in 1995 would have no perceptible effect on visibility).

286. Id. at 4-5 (tentative findings).

287. The 1977 Clean Air Act Amendments provided existing smelters with deadlines for reducing $\mathrm{SO}_{2}$ emissions that may be extended as late as 1988. 42 U.S.C. $\S 7419(\mathrm{c})$ (Supp. II 1978).

288. Memorandum from Walter C. Barber, Air Office, to David G. Hawkins, Air Office, at 1 (Apr. 12, 1979) (EPA Docket No. OAQPS-78-I, Item No. IV-B-87). This supplemental analysis predicted that use of partial rather than full scrubbing would produce perceptible differences in visual contrast by the year 2010 , precisely because visibility would be improved by that year. $I d$. at 2 (for worst case power plant conditions, and assuming large reductions in smelter emissions).

289. See pp. 1529-30 supra.

290. See note 287 supra.

291. See Protecting Visibility, supra note 206, at 5-20 to -26 (areas requiring further research).

292. See notes 272-73 supra.

293. See Protecting Visibility, supra note 206, at 2-13 to $-22,5-21$.

294. There is a final Western interest implicated by the scrubbing controversy. Environmentalists have favored scrubbing high sulfur Eastern coal in an effort to reduce 
scrubbing is not only far more expensive, but may be positively counterproductive. Even on optimistic assumptions, forcing new plants to scrub will lengthen the life of dirty plants and generate slight increases in sulfates in the populous Midwest. And once a realistic view of enforcement is taken, forced scrubbing may make the sulfate problem worse, not better, in even larger portions of the nation's vulnerable Northeastern quadrant. There must be better ways of moving beyond the New Deal.

\section{Expertise in the Service of Politics}

We can now reconstruct the basic problem confronting the EPA when Congress delivered itself of its "clarifying" amendments on August 4, 1977. On the one hand, EPA policymakers could have looked upon the incoherent last-minute statutory revision of section 111 as an invitation to analyze the scrubber carefully by exploiting the substantial talent and insight present at the middle and lower ranges of the bureaucracy. On the other hand, policymakers could have looked behind the statutory language to the legislative history and sought to implement the will of the clean air-dirty coal coalition that had lobbied the change through Congress. Although the EPA ultimately adopted the second view of its mission, this was hardly the result of a single self-conscious decision. Instead, the rejection of New Deal ideals was the outcome of a complex process of bureaucratic struggle and political intervention.

\section{A. EPA at War with Itself}

Almost immediately, the EPA found itself divided along lines that reflected Congress' problematic attempt to move beyond the New Deal.

the impact of strip mining in the West. See, e.g., Federal Coal Leasing Program: Hearing Before the Subcomm. on Minerals, Materials and Fuels of the Senate Comm. on Interior and Insular Affairs, 93d Cong., 2d Sess. 275-79, 420-25 (1974) (statement of Katherine Fletcher, Environmental Defense Fund); id. at 484-500 (statement of representatives of several environmental groups, including Sierra Club). It is not obvious, however, that the environmental damage caused by Eastern coal mines should warrant less concern than those in the West. Moreover, forced scrubbing provides a singularly ineffective way to protect the West. Even if scrubbers are installed, the EPA predicts that Western production will boom in any event. See ICF, INc., supra note 134, at A-Ib to $-7 \mathrm{~b}$. The best way to respond to the very real problems caused by strip mining is through creative efforts at reclamation. Moreover, this need has been increasingly recognized both on the federal level, with the passage of the Surface Mining Control and Reclamation Act of 1977, 30 U.S.C. $\$ \S 1201-1328$ (Supp. II 1978), and on the state level, with the enactment of increasingly high severance taxes and other devices to assure responsible reclamation practices. See, e.g., 15 MoNT. CODE ANn. $\$ 35-103$ (1979) (imposing 30\% severance tax on coal produced in state by strip-mining); 82 MONT. CODE ANN. $\$ 41-113$ (1979) (establishing special fund for land reclamation). 
On one side, the Office of Air, Noise, and Radiation (Air Office), run by Assistant Administrator David Hawkins, ${ }^{295}$ viewed section 111 in political terms. In this view, the critical point was that the clean airdirty coal lobby had succeeded in pushing something through Congress. Unless something spectacular was shown, it was wrong for an administrative agency to deny political activists the fruits of their congressional victory. At the very least, section 111, and especially its legislative history, had created a strong presumption for nationwide scrubbing, which was not to be offset by some technocratic mumbo-jumbo.

On the other side, the Office of Planning and Management (Planning Office), headed by Assistant Administrator William Drayton, represented the technocratic view. This office is composed principally of economists and policy analysts professionally predisposed to considerations of cost effectiveness. They saw forced scrubbing as a pure waste of scarce economic resources. If scrubbing was the cheapest way of meeting the NSPS standard, polluters would scrub without the need of an EPA command. Only when cheaper ways of meeting NSPS existed did the EPA's edict become significant. Moreover, the statutory language-in contrast to the legislative history-made it clear that the Administrator must take "into consideration the cost of achieving ... emission reduction" before imposing any requirement under section 111.280 Given this fact, the agency's job was not to follow through mindlessly on the congressional "decision" but to explore its policy justifications.

The conflict between the political and technocratic sides took shape early. As the bureaucratic home of the Office of Air Quality, Planning and Standards, Hawkins' Air Office had the inestimable advantage of setting the terms of intra-agency debate by making the first proposal. During late fall of 1977, the Air Office circulated a recommendation for "full scrubbing" that required all coal-burning plants not only to meet the old 1.2 limit but also to scrub ninety percent of the sulfur content out of their coal. ${ }^{297}$ In response, Drayton's Planning Office relied on a computer model to determine the costs of forced scrubbing. ${ }^{298}$

295. Although the authors attempted to discuss NSPS with Mr. Hawkins during May of 1978, this proved impossible. The descriptions of his actions were compiled through other interviews and documents available in the EPA docket.

296. 42 U.S.C. $\$ 7411$ (a)(1)(C) (Supp. II 1978).

297. See New Source Standards Considered for Utility Steam Generating Units, 8 ENVIR. REP. (BNA) 1173 (1977) (summarizing recommendation).

298. At the Planning Office's request, the EPA hired a Washington consulting firm, ICF, Inc., for modeling work that began in October 1977. An EPA official confirms that the Planning Office was the source of the proposal. Interview with EPA policy analyst, in Washington, D.C. (June 12, 1980). ICF eventually produced four separate analyses of proposed 
Because the Planning Office merely responded to the Air Office proposal, its analysis suffered from two fundamental problems. First, it did not refine the agency's understanding of the benefits of scrubbing. All NSPS proposals were analyzed exclusively in terms of $\mathrm{SO}_{2}$ even though the modelers knew of the emerging links between $\mathrm{SO}_{4}$ and more serious environmental hazards. ${ }^{299}$ This focus on $\mathrm{SO}_{2}$ also obscured the very different interests at stake in the different regions. Rather than examining impacts on health, acid rain, and visibility, the model referred only to reduction of $\mathrm{SO}_{2} \cdot{ }^{300}$

Second, the modelers examined a remarkably limited range of policy alternatives. They ignored the possibility of more sophisticated siting or design strategies. Nor did the computer study explore any option which allowed any new plant to avoid the immediate construction of scrubbers. No consideration was given, for example, to the possibility of requiring 1990 plants to burn low sulfur coal in the short term and install scrubbers in 2010, even though it was recognized that immediate

NSPS standards: Effects of Alternative Performance Standards for Co.Al-Fired Utility Bollers on Coal Markets and on Utility Capacity Expansion Plans (Sept. 1978) (prepared between October 1977 and April 1978) [hereinafter cited as ICF I]; FURTHER ANALYses of Alternative New Source Performance Standards for New Coal-Firfd PowerpLANTS (Sept. 1978) (prepared between April and September 1978) [hereinafter cited as ICF II]; Still Further Analyses of Alternative New Source Performance Standards for New CoAl-Fired Powerplants (Jan. 1979) (prepared between September and December 1978) [hereinafter cited as ICF III]; and THE Frval SET OF ANALYSEs of ALTERNative New Source Performance Standards for New Coal-Fired Powerplants (June 1979) (piepared between December 1978 and May 1979) [hereinafter cited as ICF IV]. Some results from ICF I and ICF II appeared after further analysis in ELECTRIC UTILITY STEAM GEN-

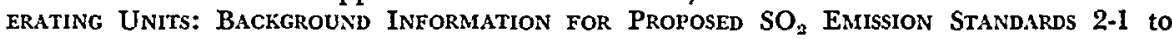
3-28 (Supp. 1978) (EPA Pub. No. 450/2-78-007a-1) thereinafter cited as $1978 \mathrm{SO}_{3} \mathrm{BACK}-$ GROUND INFORMATION (Supp.)] and in the EPA's September 1978 proposal for $\mathrm{SO}_{3}$ emission limits, 43 Fed. Reg. 42,165-68 (1978). Preliminary results from ICF III appeared in a supplemental notice, 43 Fed. Reg. 57,857-59 (1978), immediately prior to public hearings held on the proposal in December 1978. A summary of the results of ICF IV is reprinted in the EPA's publication of its decision. 44 Fed. Reg. 33,608-09 (1979).

The model's predictions varied from analysis to analysis but the trends from the various reports that are described in the text generally remained constant. For example, all the studies show the same general pattern of regional emissions. To simplify the reader's task in following the decisionmaking process, we have consistently used figures from the final analysis, ICF IV (using wet scrubbing cost assumptions, see p. 1554 infra), even though ICF IV was not available to decisionmakers until spring of 1979. Where this ahistorical simplification significantly distorts the description of events, we refer to earlier analyses.

299. See Position PAPER, supra note 88, at xiii-xiv, xvi-xvii. The agency restricted its analysis of the effect of NSPS on air quality to the regulation's impact on $\mathrm{SO}_{3}$ concentrations, making no reference to the relationship between $\mathrm{SO}_{2}$ and $\mathrm{SO}_{4}$. See $1978 \mathrm{SO}_{2}$ BACKGround INFORMATION, supra note 65 , at 6-11 to -13 .

300. See, e.g., 44 Fed. Reg. 33,605-07 (1979) (justifying 1979 NSPS simply in terms of nationwide $\mathrm{SO}_{2}$ emissions). The modelers did take a step in the right direction by projecting regional emissions of $\mathrm{SO}_{2}-$ although the regions were defined in puzzling ways. Thus, the critical Ohio Valley was divided into two different regions, following state lines rather than meteorological realities. See ICF III, supra note 298, at 15 (figure I). 
scrubbing would induce utilities to keep their dirty old plants on line longer. ${ }^{301}$ Instead, the modelers contented themselves with modest variations on Hawkins' "full scrubbing" theme. ${ }^{302}$ They focused exclusively on the costs to be saved by allowing some scrubbers to reduce $\mathrm{SO}_{2}$ discharges by something less than ninety percent. Even this cost analysis was limited by the fact that the most lenient partial scrubbing option seriously considered, permitting twenty percent scrubbing, ${ }^{303}$ still required all plants to make a very heavy initial investment in technology, and only saved some of the operation and maintenance cost of intensive ninety percent use. Finally, the model provided an unrealistic view of enforcement; by assuming perfect compliance, it failed to alert policymakers to the danger that forced scrubbing might dramatically worsen the East's sulfate problem.

In constructing its model, the Planning Office was constrained not only by the Air Office proposal but by institutional realities as well. The people at EPA best qualified to analyze environmental benefits were the agency's technical staff in North Carolina. Yet much of it was

301. The environmental groups were particularly critical of the assumption discussed above, see p. 1524 supra, that utilities would stretch out the lives of old plants when faced with increased costs for new plants. Natural Resources Defense Council \& Environmental Defense Fund, Comments on Proposed Standard of Performance for New Electric Utility Steam Generating Units, at V-3 to -6 (1978) (EPA Docket No. OAQPS-78-I, Item No. IV-D-631) [hereinafter cited as NRDC \& EDF Comments]. This is admittedly a crucial assumption. We think it is a reasonable one.

302. The modelers' praiseworthy effort to take some important variables into account should not be entirely ignored, however. An effort was made to consider the sensitivity of model conclusions to change in such variables as the growth in demand for power, the amount of nuclear capacity constructed, the prices of oil and coal, scrubber costs, and coal transportation costs. When comparing alternative standards, the model's predictions are relatively sensitive to changes in some of these assumptions-especially the costs of oil and scrubbers. See ICF III, supra note 298, at 29-31. Environmental groups strongly criticized assumptions used in the model as unjustifiably biased against full scrubbing. See NRDC \& EDF Comments, supra note 301, at V-1 to -24 . See also ICF III, supra note 298, at 23, 36 (analysis of alternative standard using NRDC's preferred assumptions which reduced emissions and increased costs in 1990 relative to standards modeled using different assumptions). Even the computer runs favored by environmentalists could not conceal the fact that forced scrubbing imposed billions of dollars more than a cost-minimizing strategy.

303. The agency itself proposed no standard requiring less than $33 \%$. See ICF III, supra note 298, at 12-17; ICF IV, supra note 298, at 3-4. The standard mentioned above was proposed by the utility industry's lobbying organization, the Utility Air Regulatory Group (UARG). See National Economic Research Associates, Inc., Comments on the Economic Impacts of EPA's September 19, 1978 Proposed Revision to New Source Performance Standards for Electric Utility Steam Generating Units 2 (Jan. 12, 1979) (EPA Docket No. OAQPS-78-I, Itcm No. IV-D-61I app. D) (discussing UARG proposal). Even so, considcration of scrubbing at levels as low as $21 \%$ was restricted to relatively uncommon, low sulfur coals (less than $0.8 \mathrm{lb}$. per MBTU). See ICF III, supra note 298, at B-21. For more common types of low sulfur coal (content of roughly 1.2 lb. per MBTU), all standards modeled, other than the then-current 1.2 standard, required at least $33 \%$ scrubbing. See id. at B-13 to -21 . 
under the bureaucratic control of Hawkins, and it would be naive to imagine that he would appreciate efforts to arm his bureaucratic opponents. Thus, the Planning Office looked outside the agency for much of its analytic assistance. It persuaded the agency to commission a Washington, D.C. consulting firm, ICF, Inc., to play a central role in building the basic model. Although this firm was well known and highly regarded for its models of coal supply and energy production, it did not have similar experience with the environmental dimensions of the problem..$^{304}$ In addition, the model's focus on coal supply encouraged the energetic participation of staffers from the Department of Energy, who saw the scrubber as a serious obstacle to energy independence. ${ }^{305}$ As a consequence, the institutional stage had been set for a computer analysis rich on costs but impoverished on the benefits that putatively justified all the activity. As a result of the Air Office's political orientation, the EPA would invest millions of dollars on an analytic enterprise that did not attempt a sophisticated advance in the environmental dimensions of the policy problem.

Yet despite its flaws, the model gave the Planning Office a powerful weapon. Even when so many critical issues had been defined out of existence, the dubious virtues of full scrubbing could not be entirely concealed. First, the model reported that full scrubbing would yield only modest nationwide gains in $\mathrm{SO}_{2}$ as late as $1995 .^{306}$ This small drop emphasized the relatively small role new plants played in the total emissions picture, as well as the fact that Eastern plants would respond to forced scrubbing by using higher sulfur coal. Regional breakdowns made the picture even less attractive. They showed that $\mathrm{SO}_{2}$ loadings would slightly increase in the Midwest, ${ }^{307}$ thereby illustrating the new

304. This characteristic was reflected in the fact that although the ICF model had been used by federal agencies to predict gross amounts of $\mathrm{SO}_{3}$ produced under various scenarios for energy development and environmental control, see, e.g., ICF, INC., IssuES AND Impacts Associated with Proposed Prevention of Significant Deterioration (1976), it was unable to estimate how emissions of $\mathrm{SO}_{2}$ translated into concentrations of $\mathrm{SO}_{4}$, see ICF, INC., CoAl and Electric Utilities Model Documentation I-I to -11 (1977) (sum. marizing model capabilities). This transformation posed a key health question. See p. 1517 supra.

305. Full scrubbing promised to increase oil consumption by roughly 250,000 barrels a day compared to most other compliance strategies, see ICF IV, supra note 298 , at 5 , which is roughly $1 \%$ of current American consumption, see ENERGY Future: REPORT of THE Energy Project at the Harvard Business School, supra note 5, at 15 (table I-1) (1977 daily consumption of petroleum equivalent to 18.4 million barrels of oil). See pp. 1542, 1553 infra (discussing DOE participation).

306. See $1978 \mathrm{SO}_{3}$ BACKGROUnd Information (Supp.), supra note 298, at 3-5 (table 3-2) (predicting less than $5 \%$ difference in emissions nationwide between standards requiring nearly universal use of $90 \%$ scrubbing and alternative "partial" scrubbing options).

307. See ICF IV, supra note 298 , at C-II-3a, C-VIII-3a (predicting $3 \%$ increase in emission tonnages in East North Central region by 1995). The East North Central region in 
incentives that scrubbing would give utilities to keep their old, dirty plants on line longer. ${ }^{308}$ The model also revealed that full scrubbing was one of the costliest ventures ever imposed in the name of a cleaner environment. Full scrubbing would cost 4.1 billion dollars a year by $1995^{300}$ and even more in later years as more new plants were built.

As the computers clacked on, the agency began to confront yet another congressional constraint on its discretion. As part of its last-minute activity, the conference committee had imposed a one-year deadline for the EPA to implement the revised version of section $111 .{ }^{310}$ When it became clear in July 1978 that regulations would not be proposed, let alone promulgated, by the deadline, the Sierra Club successfully obtained a court order requiring an EPA decision by June $1979 .^{311}$ This timetable required rapid publication of a notice of proposed rulemaking; thus, during the summer of 1978, the scrubbing issue began to loom large on Administrator Costle's personal agenda. Moreover, intra-agency conflict had the great merit of forcing Administrator Costle to give more time to the issue than any previous policymaker of like stature-either in Congress or the executive branch. Yet the dispute reached Costle through the distorting institutional prism bequeathed by the congressional effort to move beyond the New Deal. On the one hand, the Air Office kept its eyes firmly fixed on the legislative history and so believed that a sophisticated analysis of environmental consequences was unnecessary for its extreme position on behalf of full scrubbing. On the other hand, the Planning Office, together with its consulting firm, expatiated on the costs with only the most meager institutional capacity to speak

cludes Illinois, Indiana, Michigan, Ohio, and Wisconsin. When speaking of air quality, we will refer to this region as the Midwest. When coal-producing regions are described, Ohio is part of the Appalachian region, not of the Midwestern region. The EPA, in its September 1978 notice, used a slightly different definition of "Midwestern," resulting in a slight decrease in predicted emissions from the "Midwest." 43 Fed. Reg. 42,165 (1978).

308. See 44 Fed. Reg. 33,607 (1979) (higher pollution control costs of new plants induce utilities to use older plants).

309. See ICF IV, supra note 298, at 5. The September notice predicted an increase of \$2.6 billion. 43 Fed. Reg. 42,168 (1978) (table 8). Cost figures here and elsewhere are incremental annualized costs relative to the 1.2 standard. They include annualized capital costs as well as operating and maintenance costs. These figures do not represent the total annualized investment that utilities will make for pollution control in 1995, in that the costs necessary to reach the 1.2 standard are not counted. Other consultants have predicted that continued use of the 1971 NSPS would cost about $\$ 6$ billion in 1990 (in annualized 1977 dollars). See $1978 \mathrm{SO}_{2}$ BACKGROUND InForMation (Supp.), supra note 298, at 3-28.

310. Clean Air Act Amendments of 1977, § 109(a), 42 U.S.C. $\$ 7411(f)$ (I) (Supp. II 1978).

311. Sierra Club v. Costle, No. $76-1297$ (D.D.C., Aug. 25, 1978) (stipulation) (EPA Dacket No. OAQPS-78-I, Item No. II-F-1, IV-J-25); see 9 ENVIR. REP. (BNA) 543, 544 (1978). 
intelligently on the question whether the costs were worth bearing. Rather than a coordinated institutional effort to define short- and long-term strategies to cope with the sulfate problem, Costle was presented with dollar figures, on the one hand, and clean air rhetoric, on the other.

\section{B. Executive Intervention}

In deciding on the proposal that the EPA would announce in the Federal Register, Costle was hardly operating in an insulated bureaucratic environment. From the time the Air Office circulated its first internal memo on behalf of full scrubbing, outsiders were informed of agency policy through agency leaks or by BNA's Environment Reporter. $^{312}$ Thus, they could intervene informally even before the EPA proposal was published on September 19, 1978.

The critical mover at this stage was the Department of Energy (DOE). Once the scrubbing issue was isolated from the swirl of comprehensive energy planning, the DOE staff could assert its continuing doubts about scrubbing. ${ }^{313}$ As Costle approached his decision in the summer of 1978, DOE opposed the Air Office proposal in increasingly aggressive ways ${ }^{314}$ and endorsed partial scrubbing. In a memorandum presented at an August White House meeting, Costle asserted that the statute contained a presumption favoring full scrubbing, but admitted that further analysis could overcome that presumption. ${ }^{315}$ Rather than choose sides, Costle permitted the agency's formal notice to reflect the bureaucratic impasse. ${ }^{316}$ The notice announced the Air Office requirement that all new plants reduce sulfur content by ninety percent in addition to complying with the old 1.2 ceiling, ${ }^{317}$ but it also reported

312. In addition, the EPA routinely submitted its proposals to other exccutive offices for review. See, e.g., Letter from Don R. Goodwin, Air Office, to Addressees in other Executive Agencies (Dec. I, 1977) (EPA Docket No. OAQPS-78-I, Item No. II-F-1) (enclosure of draft NSPS provisions).

313. See, e.g., Letter from John F. O'Leary, DOE Deputy Sccretary, to Douglas C. Costle, EPA Administrator (July 6, 1978) (EPA Docket No. OAQPS-78-I, Item No. II-F-4); Letter from John F. O'Leary to Douglas C. Costle (Aug. 11, 1978) (EPA Docket No. OAQPS-78-I, Item No. II-F-5).

314. See, e.g., 9 ENvir. REP. (BNA) $436-37$ (1978) (summarizing DOE opposition); id. at 660 (reviewing letter from $O^{\prime}$ Leary to Costle, favoring sliding scale emission standard).

315. See id. at 819; id. at 860 (reprinting memorandum).

316. See 43 Fed. Reg. 42,154 (1978) (principal issue to be resolved in rulemaking is whether full scrubbing of low sulfur coal is required). The EPA's eventual decision to propose a standard-full scrubbing-rather than simply state the alternatives being considered, was influenced by a provision of $\$ 111$ which subjected plants to the revised NSPS from the date of proposal, not of promulgation. See 42 U.S.C. $\$ 7411$ (a)(2) (Supp. II 1978); 9 ENvir. Rep. (BNA) 861 n.l (1978).

317. The September notice actually proposed a 1.2 ceiling with certain exemptions and scrubber performance averaging $85 \%$-measured on a daily basis. See id. at 42,158 .

Most alternative standards considered after September 1978 were formulated in terms 
the dismal story that the model was telling about full scrubbing. ${ }^{318}$ To make matters even clearer, Costle had publicly declared that his mind was open. ${ }^{319}$ Scrubbing would finally be given the high-visibility attention it deserved.

\section{Technocratic Ascendancy}

Their work now acknowledged by the Administrator, the computer modelers proceeded in earnest and produced an alternative to the Air Office's full-scrubbing proposal. Although the Planning Office had already narrowed its inquiry greatly, there was one well-known theme that could be played in countless variations.

\section{The Rise of Partial Scrubbing}

It is the old siren song of Pareto efficiency. It is child's play to show that any emission reduction achieved by ninety percent scrubbing can be achieved more cheaply by more intelligent regulation. As we have seen, when Eastern coalburners are forced to scrub at ninety percent, they will sometimes respond by buying cheap high sulfur coal, thereby offsetting the scrubber's emission reduction by increasing the total sulfur content of the fuel consumed. This simple point suggested the possibility of a Pareto-efficient bargain, a "sliding scale" approach to emission reduction. For example, if the utility promised to discharge only 0.8 rather than 1.2 pounds per MBTU, then the EPA might agree to forgo its ninety percent scrubbing requirement and permit some lower level of percentage removal, say thirty-three percent. Under this alternative, the environment would gain a little by means of the reduction from 1.2 to 0.8 , and the utilities would gain because scrubbing at thirty-three percent was less expensive than scrubbing at ninety

of monthly or yearly averages. In general, a standard expressed as a daily average appears to be less stringent than the same standard expressed as a long-term average. For example, EPA analysts interviewed stated that they had generally considered the September notice's 1.2 standard (with exemptions) to be equivalent to approximately a 0.8 pound annual average. During the modeling process, a requirement that a scrubber reduce emissions by an average of $85 \%$ every day was generally considered to be equivalent to a requirement that it reduce emissions by an average of $90 \%$ over a longer period such as a month or a year. See, e.g., ICF II, supra note 298 , at A2. For the reader's convenience, the authors have translated percentage reduction requirements into equivalent long-term averages throughout. Where the text refers to $90 \%$ scrubbing, long-term averages should be assumed unless otherwise noted.

318. See 43 Fed. Reg. 42,166-67 (tables 4, 5) (1978) (showing little change in new plant $\mathrm{SO}_{2}$ emissions in most of country from different scrubbing standards).

319. See 9 ENVIR. REP. (BNA) 861 (1978) (reprinting Costle memorandum declaring that September notice will seek further information to help EPA make decision). 
percent ${ }^{320}$ Only sellers of the dirtiest coals could possibly lose. Moreover, because the agency computer model was relatively sophisticated in its treatment of coal production, it could predict confidently that partial scrubbing options would do no serious economic harm to Eastern coal. Indeed, major increases in overall Eastern coal production were anticipated. ${ }^{321}$

There was, however, one interest that could not be accommodated by the use of the sliding scale. In the West, a ninety percent scrubber did imply a ninety percent reduction in new plant emissions since only low sulfur coal was readily available. Gains from ninety percent scrubbing would be offset by increased use of old plants, but the model still predicted a modest reduction in Western $\mathrm{SO}_{2}$ loadings by $1995 .{ }^{322}$ Modelers seeking Pareto superiority therefore made a regulatory distinction between East and West: Easterners might be allowed the benefits of the sliding scale, while Westerners might be forced to accept the rigors of full scrubbing. Here, finally, was something that made nobody worse off and that had the advantage of providing both branches of the EPA with a face-saving compromise. Yet although this "Eastern sliding scale-Western full scrubbing" proposal was Pareto superior to the full scrubbing proposed by the Air Office, it emphasized the bizarre quality of the entire exercise. After all, it was the East that suffered more severely from acid rain and the possibility of health impairments. Nonetheless, the East-West split would permit many Eastern plants to keep discharging at 1.2 when all Western plants were discharging at $\mathbf{0 . 2}$.

Although this bizarre solution did not force the reconsideration of basic premises, it did lead the technocrats to favor an alternative proposal that would tolerate some increases in $\mathrm{SO}_{2}$ in the West while reducing Eastern loads more significantly. Moreover, this solution had the virtue of administrative simplicity and served to emphasize the economists' main insight. Why not simply reduce the old 1.2 emission

320. Because partial scrubbing options reduced the cost of new plants, and thus encouraged the retirement of dirtier, old plants, partial scrubbing could produce net reductions in emissions, even where its use did not reduce emissions from individual plants. See p. 1524 supra.

321. Nationwide coal production was expected almost to triple between 1975 and 1995 . Even under the 1.2 standard, ICF predicted that over those twenty years production would increase by $25 \%$ in Appalachia, by $190 \%$ in the Midwest, and by $750 \%$ west of the Mississippi. ICF IV, supra note 298, at C-II-9.

322. The reduction was modest because smelters, not power plants, contribute most of the region's $\mathrm{SO}_{2}$. See notes 284-85 supra. ICF predicted, though, that under some partial scrubbing options, power plant $\mathrm{SO}_{2}$ emissions mighe be $50 \%$ greater than under a full scrubbing standard. See ICF III, supra note 298, at D-III-2. 
ceiling to some lower number, say $0.55,{ }^{323}$ which would force everyone to scrub somewhat since no coal could pass the lower ceiling without advanced technology? Despite this radical reduction of the output ceiling, costs would nonetheless be reduced so long as polluters were allowed to decide for themselves how to mix lower sulfur coal and higher scrubbing percentages to reach the 0.55 ceiling. Compared to full scrubbing, the simple proposal to lower the ceiling to 0.55 promised savings of hundreds of millions of dollars a year, lower $\mathrm{SO}_{2}$ emissions nationwide, and significant emission reductions in the areas east of the Mississippi where the health threat was most serious. ${ }^{324}$

By January 1979, opinion within the Planning Office was converging strongly upon this simple "ceiling reduction" proposal. Rational analysis had paid off: no serious person could think that the Air Office's proposal for full scrubbing was superior to the simple expedient of lowering the ceiling to 0.55 . And it was at just this point that the technocrats in the agency gained important reinforcement from on high, as the White House staff added its weight to the technocratic counterattack.

\section{The View from the Center}

In the early days of the Carter Administration, center stage was occupied by Schlesinger's heady energy program; by 1978, however, the scrubber was worthy of attention in its own right. As the White House staff became familiar with their offices, they tried-as have so many predecessors-to gain control over the sprawling bureaucracy around them. The organizational initiative of greatest interest here is the White House effort to implement a 1978 executive order, requiring the agencies to conduct an "economic impact analysis" for every "significant" regulation. ${ }^{325}$ The core of this effort was the so-called Regulatory

323. The 0.55 pound standard discussed here and below was based on an annual average. The Air Office proposal was equivalent to roughly a 0.8 to 1.0 pound standard on an annual basis. See note 317 supra.

324. According to the model, a simple 0.55 limit was cheaper than full scrubbing with washing credit by $\$ 800$ million a year in 1995 . At the same time, nationwide $\mathrm{SO}_{2}$ emissions from power plants went from 20.5 million tons under full scrubbing to 20.3 million under the lowered ceiling. The low ceiling, more importantly, reduced Eastern loadings by 740,000 tons in 1995, from 15.6 million tons to 14.9 million tons. See ICF III, supra note 298 , at D-III-I to -2 (net difference obtained using independent rounding). In contrast, emissions in the West, where sulfur oxide levels are lower than in the East, rose by only 560,000 tons, from 4.9 million tons to 5.4 million tons. Id.

325. Exec. Order No. 12,044, 3 C.F.R. 152 (1979). "Significant" regulations are those that impose costs of $\$ 100$ million annually, or that have major impacts on individual industries, levels of local government, or geographic regions. Id. at $\S 3($ a)(1), 3 C.F.R. 152, 154 (1979). 
Analysis Review Group (RARG)-a bureaucratic box in which Executive Office economists confronted ambassadors from Cabinet-level agencies. ${ }^{326}$ Formally speaking, the RARG job was to review the analysis generated by the front-line agency in defense of its proposed initiative, and publish a report of its findings for inclusion in the agency's rulemaking record ${ }^{327}$ Although this makes the RARG potentially significant in the practice of judicial review, ${ }^{328}$ our present concern is with its direct impact on policymaking.

NSPS was an ideal candidate for RARG review. Its multibillion dollar annual price tag naturally invited inquiry from the cost-benefit analysts in the Executive Office. DOE opposition suggested the need for central coordination. Finally, expressions of concern from the business community ${ }^{329}$ signaled the presence of political interests not readily appreciated by the EPA. Accordingly, RARG dispatched a single junior lawyer-economist, Robert Litan, for a three-month tour with the EPA's modelers. Litan and other lawyer-economists then worked with William Nordhaus, a senior member of the Council of Economic Advisers, to prepare a RARG report on NSPS.

The report ${ }^{330}$ suggested the value of review by technocratically competent staff operating outside the control of the agencies. ${ }^{331}$ It brought to the surface some of the larger questions that had been

326. RARG is chaired by the Chairman of the Council of Economic Advisers and includes "economic" and "regulatory" members. Representatives of CEA, the Office of Management and Budget, and the Departments of Commerce, Labor, and Treasury constitute the "economic" group. "Regulatory" members are representatives of the Health and Human Services, Housing and Urban Development, Interior, Justice, and Transportation Departments, and the EPA. The Office of Science and Technology Policy participates in RARG as a member, and the President's Domestic Policy Staff and the Council on Environmental Quality participate as advisers. See Procedures of the Regulatory Analysis Review Group (Nov. 1978) (unsigned memorandum) (on file with Yale Law Journal).

327. RARG reports are formally submitted by the Council on Wage and Price Stability (COWPS), which operates with explicit statutory authority to intervene in the rulemaking of agencies in order to present its views on the inflationary impact of decisions. See 12 U.S.C. $\$ 1904$ (Supp. II 1978). Presumably this reliance on COWPS is intended to minimize questions of the improper use of executive power to influence regulatory decisions.

328. See pp. 1561-62 infra.

329. See Letter from George C. Freeman, Jr. to Stuart Eizenstat (Aug. 18, 1978) (EPA Docket No. OAQPS-78-I, Item No. II-D-433) (restating concern expressed at July 13 meeting with Eizenstat); Letter from Barbara Blum, Deputy Administrator, EPA, to James Schlesinger (July 6, 1978) (EPA Docket No. OAQPS-78-I, Item No. II-F-7) (referring to meeting on NSPS with President, Schlesinger, and Business Roundtable).

330. Council on Wage and Price Stability, Environmental Protection Agency's Proposal for the Revision of New Source Performance Standards for Electric Utility Steam Generating Units, Report of the Regulatory Analysis Review Group (Jan. 15, 1979) (EPA Docket No. OAQPS-78-I, Item No. IV-H-12) [hereinafter cited as RARG Report].

331. See B. Ackerman, S. Rose-Ackerman, J. Sawyer, \& D. Henderson, supra note 237, at 156-71. 
suppressed by the bureaucratic struggle within the EPA. Most important, the report focused on the peculiar fact that the EPA had failed to illuminate the environmental dimensions of the problem in a sophisticated way. It challenged the EPA's concentration on $\mathrm{SO}_{2}$ rather than on $\mathrm{SO}_{4} .^{332}$ Moreover, it showed the irrationality of examining total pounds of $\mathrm{SO}_{2}$ emitted without taking account of the number of people actually exposed to emissions and recommended further analysis of health and exposure effects before embarking on a massive program of forced scrubbing. ${ }^{333}$ The RARG report did not, however, make a systematic effort to measure scrubbing against the various goals-human health, ecological integrity, aesthetic visibility-relevant in a comprehensive analysis. Instead, it concerned itself primarily with the battle already raging within the EPA and came out in favor of the Planning Office proposal to lower the ceiling from 1.2 to some lower number and to permit utilities to mix scrubbing and low sulfur coal in the way that would most cheaply meet the output ceiling. ${ }^{334}$

All in all, RARG did a remarkably good job with the resources at its disposal. It discharged the most fundamental reviewing task, challenging the agency's narrow definition of its problem, and pointing out concrete ways in which the problem might be redefined usefully. In addition, given the way the problem had been defined, RARG properly placed the burden of justification on the side that seemed to have the worst of the technocratic argument. Finally, unlike judicial review, RARG review came at a time before bureaucratic positions had hardened beyond alteration. The RARG report was filed on the last day for public comment on the EPA's September proposal. ${ }^{335}$ The time had come for Administrator Costle to make up his mind.

\section{Agency Decision}

As the comment period closed on January 15, 1979, the agency's perception of NSPS had matured significantly in the year since Hawkins' Air Office first proposed its full scrubbing-high ceiling option. RARG's narrowly focused rejection of full scrubbing on behalf of a lowered ceiling had a sizable impact. It enhanced the internal credi-

332. See RARG Report, supra note 330, at 29.

333. See id. at $26-35,42$. Although representatives of the Council of Economic Advisers had earlier requested the EPA to conduct a benefits study as part of the NSPS rulemaking, the Air Office opposed committing resources to such a study. See Memorandum from Walter C. Barber, Air Office, to Roy N. Gamse, Planning Office (Aug. 9, 1978) (suggesting feasibility problems of such study) (on file with Yale Law Journal).

334. See RARG Report, supra note 330, at 2, 13-14.

335. Id. (report submitted January 15, 1979). 
bility of the EPA's Planning Office and demonstrated that other bureaucracies, notably DOE, would have significant support in the White House if the EPA entirely ignored their opposition to full scrubbing. Moreover, the technocrats had plainly made a powerful case for the low ceiling strategy. Analysis suggested that the 0.55 ceiling would reduce 1995 nationwide emissions by 0.2 million tons more than full scrubbing while costing $\$ 800$ million dollars a year less. ${ }^{336}$

\section{The High Tide of Instrumental Rationality}

If the symbol of full scrubbing were to emerge victorious, something new would have to be added to the bureaucratic equation. And this "special something" was precisely what Hawkins' Air Office tried to provide. So far as a committed environmentalist was concerned, there was nothing wrong with the Planning Office's proposal to lower the ceiling from 1.2 to 0.55 . But it would be even better to add a full scrubbing requirement on top of this, thereby reducing Western emissions yet further to 0.2 pounds of $\mathrm{SO}_{2}$ per MBTU. ${ }^{337}$ Thus, during January and February, the Air Office independently began to study a low ceiling-full scrubbing proposal as an alternative to the Planning Office's low ceiling-partial scrubbing competitor. While Planning Office computer projections concentrated on the year 1995, the Air Office focused on 2010 or later. ${ }^{338}$ By looking far into the future, the Air Office modeling effort magnified the significance of the difference between 0.2 and 0.55 in the West. ${ }^{339}$ By 2010 , the model predicted that Western power plants would generate 4.4 million tons of $\mathrm{SO}_{2}$ under a 0.55 limit, while only three million tons would result under a ninety percent scrubbing standard. ${ }^{340} \mathrm{Hence}$, according to the Air Office, the need for full scrubbing had been reestablished on firm technocratic ground.

The unreality of these projections, however, was easily unmasked when they came to Planning Office attention in February 1979. Because NSPS would be reconsidered between now and 2010, it was wrong

336. See ICF III, supra note 298, at 37. The difference in emissions is $1 \%$ of predicted nationwide emissions, and may not be significant.

337. In December 1978, ICF predicted that in 1995 a low ceiling-full scrubbing option would yield 500,000 tons less in emissions nationwide than the 0.55 limit alone and would increase annualized costs by $\$ 1$ billion. See id. Almost all of the decrease in emissions would occur west of the Mississippi. See id. at D-III-1.

338. For this reason, the Planning Office criticized the projections as unfair. See Memorandum from Roy N. Gamse, Planning Office, to Walter C. Barber, Air Office (Feb. 28, 1979) (on file with Yale Law Journal).

339. See id.

340. See ICF IV, supra note 298, at D-Ia. 
to ignore the possibility of tightening up more in the future even if the 1980 NSPS was "only" set at $0.55 .^{341}$ Moreover, in its zeal to establish the benefits of full scrubbing in 2010, the Air Office had entirely failed to estimate the costs imposed on new plants built between 1995 and 2010. Later on, these added costs were placed at six billion dollars a year. $^{342}$ Finally, the Air Office failed to note the overwhelming contribution of smelting to Western sulfur loadings. Because the smelters were expected to reduce their discharges substantially over the next half century, it was likely that even with the 0.55 limit, overall $\mathrm{SO}_{2}$ loads would remain constant, or even decline. ${ }^{343}$ These flaws undermined the Air Office's belated effort to defend itself with the flashy weapons brandished by its opponents.

A related clean air effort, however, did manage a brief moment in the sun. During February, the EPA circulated a partial scrubbing-low ceiling proposal to other executive departments for comment. ${ }^{344}$ In response, the Department of the Interior expressed concern about future visibility in the Western national parks in its bureaucratic bailiwick. ${ }^{345}$ Because Interior's mission did not oblige it to take any of the other costs, environmental or financial, into account, there was nothing preventing it from pronouncing itself in favor of full scrubbing. Not content with a paper statement, Secretary Andrus met with Administrator Costle to express his opposition to partial scrubbing. ${ }^{346}$ Shortly thereafter, Interior made a formal presentation to the EPA's Air Office, dramatizing its concern with a slide-show depicting on separate slides a hazy Grand Canyon and belching smokestacks. Unfortunately, how-

341. See Memorandum from Roy N. Gamse to Walter C. Barber, supra note 338.

342. See ICF IV, supra note 298, at D-1a.

343. In 1975, smelters emitted 2.2 million tons in the Rocky Mountain and Pacific regions, and power plants emitted only 0.6 million tons. See Memorandum from David W. Tunderman, Planning Office, to William Drayton, at 3 (Mar. 9, 1979) (figure 1) (on file with Yale Law Journal). By 1995, smelter emissions are expected to decline by an amount between 1.1 and 1.6 million tons. Under a 0.55 standard, $\mathrm{SO}_{2}$ emissions from utilities in the Western regions should increase by only 0.6 million tons between now and 2010-thus suggesting there will be little change in emissions in the Rocky Mountain and Pacific states. See id. (showing smelter emissions decline); ICF IV, supra note 298, at $\mathrm{D}-\mathrm{la}$ (showing increase in $\mathrm{SO}_{2}$ emissions).

In contrast to the West, states lying between the Mississippi and Rockies (the model's Central West region) might experience an increase in emissions of an additional 800,000 tons, assuming partial scrubbing and no NSPS revisions. See ICF IV, supra note 298, at D.1a.

344. See Memorandum from Walter C. Barber, Air Office, to the Files (undated) (EPA Docket No. OAQPS-78-I, Item No. IV-E-16) (report of EPA briefing held for Office of Management and Budget and Departments of Agriculture and Interior, Feb. 16, 1979).

345. See id. (attachments $\mathrm{D}, \mathrm{E}$ ) (summarizing briefing of Interior and other departments on NSPS and attaching Interior material on visibility problem).

346. See Memorandum from Walter C. Barber to the Files (May, 1979) (EPA Docket No. OAQPS-78-I, Item No. IV-E-18) (summarizing meeting). 
ever, Interior was entirely unable to establish any causal link between the two halves of its slide-show. As we have seen, the smokestack's visible plume is not the product of $\mathrm{SO}_{2} ;{ }^{347}$ moreover, given present emissions, it is Arizona's smelters, not coalburners, that may be responsible for a hazy Canyon-if the haze is to be explained principally by man-made sources. ${ }^{348}$

Quickly discredited, the visibility argument on behalf of full scrubbing dropped out of sight during the last hectic months ${ }^{3 * 9}$-only to reemerge at the final press conference, when slides of smoggy Western wonders once again graced the walls as Administrator Costle announced the EPA decision.

\section{Political Counterattack}

By mid-March, then, the clean air wing of the government had failed to sustain its opposition to a technocratic solution of section 111. The time had come for the second half of the clean air-dirty coal coalition to make itself felt. So far as Eastern coal interests were concerned, lowering the emission ceiling to 0.55 deprived them of their hard fought victory in the committee rooms of Congress. Such a low ceiling would make it impossible to scrub the higher sulfur Eastern varieties into compliance; and the EPA retreat to partial scrubbing continued to allow utilities to look westward for low sulfur coal when this minimized their costs.

The coalition between dirty coal and clean air that influenced the congressional struggle of 1977 could not fulfill the coal lobby's needs in 1979. Environmentalists saw full scrubbing as a symbolically effective way to minimize emissions. For them, the new section 111 succeeded insofar as it induced the EPA to reduce the ceiling from 1.2 to 0.55 . Although they preferred to go further and require full scrubbing in the West, they abandoned the 1.2 ceiling. ${ }^{350}$

In contrast, the utilities welcomed their errant friends from the coal industry back into a dirty coal-dirty air alliance to resist the low ceiling. To the utilities, reducing the ceiling from 1.2 to 0.55 imposed crushing expenses; and they were happy to make the Eastern mining com-

347. See p. 1533 supra.

348. See pp. 1534-35 supra; Protecting Visibility, supra note 206, at 6-5 to -7 (discussing contribution of windblown dust to visibility impairment).

349. See Memorandum from Walter C. Barber to David G. Hawkins, supra note 288 (opinion of experts that difference between full and partial scrubbing would have no perceptible region-wide effects in 1995).

350. See NRDC \& EDF Comments, supra note 301, at IV-6 (advocating 95\% scrubbing with ceilings from 0.4 to $0.12 \mathrm{lb}$ ). 
plaint a part of their own rhetoric, with utility spokesmen decrying the preclusionary effect of a lower ceiling on Eastern coal. ${ }^{351}$ Although the formal comment period had closed in January, the fact was that the EPA's low ceiling proposal had only matured more recently. As a consequence, the EPA responded to the coal lobby protest by holding a public meeting on April 5, at which the National Coal Association (NCA) presented an estimate that a 0.55 limit would preclude from seventy-five to one hundred percent of the coal produced in five Eastern regions. ${ }^{352}$

This counteroffensive hardly took EPA's technocrats by surprise. The Planning Office computer runs had included a careful study of NSPS's impact on Eastern coal mining, and these projections had consistently shown increases in Eastern coal production through 1995. ${ }^{353}$ Because most existing power plants would not be retired before 1995, ${ }^{\mathbf{3 5 4}}$ their demand for high sulfur products would remain intact. ${ }^{355}$ In addition, the plants of the early- and mid-1980s, regulated by the old NSPS of 1.2, would add to the demand for Eastern coals in the mid-sulfur range. ${ }^{356}$ Even if Planning Office simulations had gone haywire, the NCA's definition of mining regions was artfully devised to exclude major Eastern zones of low sulfur coal; hence its claims of seventy-five to one hundred percent preclusion exaggerated the low ceiling's impact. ${ }^{357}$

351. See 9 Envir. REP. (BNA) 2100 (1979) (statement of George C. Freeman, Jr.).

352. See Minutes of April 5, 1979 Meeting Concerning Coal Reserve Data and Application of Physical Coal Cleaning Credits (attachment 8) (EPA Docket No. OAQPS-78-I, Item No. IV-E-11). The NCA survey included reserves from Ohio, Illinois, Indiana, northern West Virginia, and western Kentucky, and was based on an assumption of $85 \%$ scrubbing.

353. See ICF IV, supra note 298 , at A-1b to A-7b. Even under a 0.55 ceiling, Eastern coal production was predicted to increase by 55\%. See id. at A-3b (1995 figures); id. at C-II-9 (1975 figures).

354. See id. at C-II-I5.

355. Id.

356. Existing plants (including plants converted from oil) and old NSPS plants will together require $40 \%$ more coal in 1995 than power plants consumed in 1975. See id. By themselves, plants subject to the 1979 NSPS will, in 1995, consume more coal than all utilities did in 1975 . Id.

357. The NCA survey ignored southern West Virginia and eastern Kentucky. In these two regions $92 \%$ of the reserves could meet a low ceiling, even using conservative assumptions. See M. Wells, R. Chapman, R. Yeager, V. Nereo, \& V. Matucha, Coal Resources and Sulfur Emissions Regulations 6-3 (1980) (table 6-1) (Teknekron Report to EPA, Contract No. 68-02-3136) (data showing $92 \%$ of coal reserves (weighted average) in these two regions has sulfur content of $3.0 \mathrm{lb}$ per MBTU or less ( 0.55 ceiling can be met by using coal containing $3.67 \mathrm{lb}$ per MBTU or less)). Although the EPA did not emphasize this omission, it did counter with an analysis that, by redefining relevant coal reserves and mining regions, suggested that a low ceiling precluded no more than $35 \%$ of reserves in the Appalachian region (Ohio, northern West Virginia, and Pennsylvania), and no more than $75 \%$ in the Midwest (Illinois, Indiana, and western Kentucky). See Minutes of April 5, 1979 Meeting, supra note 352 (attachment 3) (Memorandum from John D. Crenshaw to John Haines (Mar. 30, 1979)). More realistic assumptions reduced precluded reserves to $25 \%$ or less in both regions. See $i d$. 
What is more, the NGA's entire conceptual exercise was radically misconceived. Measuring preclusion in percentage terms ignores the fact that, given the East's rich reserves, even a small percentage will keep miners fully occupied for a long time; thus, 1978 Eastern production was 0.17 percent of total reserves. ${ }^{358}$ So long as we assume that the technology of 2050 will be vastly superior to the scrubbers of today, it seems fair to leave the higher sulfur coal to tomorrow's treatment.

In making these points, we do not mean to suggest that the NCA presentation fooled anybody. To the contrary, the inadequacies of the preclusion analysis were well recognized by the EPA bureaucracy. Nonetheless, the agency was not in a position to give this special pleading the treatment it deserved. First, the congressional action of 1977-whatever its proper interpretation-was widely perceived as mandating a concern for "locally available fuels" as much as a desire for clean air. Second, and even more fundamentally, the agency thought that it could frame a new NSPS standard without engaging in a careful instrumental study of the benefits it would yield. ${ }^{359}$ When faced with the inevitable cries of discomfort from cost-bearers, it could not now defend itself by explaining why the costs were worth bearing. Instead of countering the preclusion issue by pointing to the environmental benefits of a low ceiling, the EPA found the issue being defined in terms of political costbenefit. So far as the coal industry was concerned, the EPA was breaking a promise explicitly made in the legislative history. And it would take energetic steps to bring the technocrats back into line with congressional intention.

As April moved on, the big political guns moved in. Senate Majority Leader Robert Byrd of West Virginia met with Costle and Eizenstat at the White House on April $23^{360}$ and with other EPA officials on May 2,301 After the first meeting, Costle indicated that the agency did not intend to rule out large portions of Eastern or Midwestern coal re-

358. See Memorandum from John D. Crenshaw to Walter C. Barber (May 11, 1979) (EPA Docket No. OAQPS-78-I, Item No. IV-B-72) (using regions surveyed by NCA, plus Pennsylvania).

359. See Memorandum from Walter C. Barber to Roy Gamse, supra note 333 (refusing Council of Economic Advisers' request to do benefit analysis).

360. See Memorandum from David G. Hawkins to NSPS Docket (Apr. 26, 1979) (EPA Docket No. OAQPS-78-I, Item No. IV-E-13).

361. See Memorandum from David G. Hawkins to Walter C. Barber (May 3, 1979) (EPA Docket No. OAQPS-78-I, Item No. IV-E-24). Other coal state Congressmen supported Senator Byrd. The EPA docket contains over a dozen communications (by letter) between concerned Representatives and the EPA. See EPA Docket No. OAQPS-78-I, Item Nos. IVD.764 to -880 (interspersed comments of individual Congressmen). 
serves. ${ }^{362}$ Capitulation followed. Not only did the EPA retreat from the 0.55 standard to the old 1.2 ceiling, ${ }^{363}$ it also resolved technical ambiguities surrounding the old 1971 number in ways that permitted new plants to increase legal discharges by as much as fifty percent. ${ }^{361}$ At this new level, only three percent of Eastern coal would be precluded from the market, ${ }^{365}$ leaving the nation free to choose its 0.2 percent annual requirement from the remaining ninety-seven.

The political whirlpool was propelling Administrator Costle back to the 1978 Air Office proposal, which required everybody to use ninety percent scrubbing under a 1.2 ceiling. Yet too much had happened to make this giant step backward easy to manage. Not only were there reams of computer printout detailing the weaknesses of the Air Office approach, ${ }^{366}$ but powerful bureaucracies were committed to the printout. Within the agency, a full scrubbing decision under external political pressure would demoralize the Planning Office. Outside the agency, the Department of Energy remained adamantly opposed to a proposal that would place a four billion dollar annual burden on energy independence by $1995 .^{307}$ Finally, the technocrats in the Executive Office were willing to defend its RARG report at any final confrontation.

But no bureaucrat likes confrontation. At the same time the EPA was propitiating Senator Byrd, it also tried to do homage to the gods of economic rationality. Ten days after the formal National Coal Association presentation, an internal memorandum suggested the high

362. See Memorandum from David G. Hawkins to NSPS Docket, supra note 360 .

363. The rationale for the retreat to 1.2 is explained in Memorandum from John $D$. Crenshaw to Walter C. Barber, supra note 358. The technical analysis underlying the Crenshaw memorandum was completely developed by the May 2 meeting, when it was distributed to attendees. See Memorandum from David G. Hawkins to Walter C. Barber, supra note 361 (enclosing distributed material). The docket does not indicate whether the Administrator at that time indicated his decision to adopt the new 1.2 standard. The EPA has since reported that the Administrator had already concluded that "anything more than minimal preclusion" would have been inconsistent with the purposes of the 1977 Amendments. See 45 Fed. Reg. 8215 (1980).

364. The 1971 NSPS did not explicitly state the period of time during which a plant was required to maintain the 1.2 emission ceiling. However, a new plant was required to pass a three-hour performance test. See 40 C.F.R. $\$ 60.45$ (g)(2)(i) (1979). If this three-hour test had been incorporated in the new regulations, the effective results would have been far more restrictive than the new regulation-which only requires plants to meet a 1.2 monthly average. 40 C.F.R. $\$ 60.43 \mathrm{a}(\mathrm{c})$ (1979). The $50 \%$ figure presented in the text is based on interviews with experts both in and out of the agency.

365. Memorandum from John D. Crenshaw to Walter C. Barber, supra note 358, at 6.

366. See ICF III, supra note 298, at 19, 21 (figure 2) (concluding that proposed 1.2-90\% standard was least efficient of those modeled between September and December 1978).

367. For a clear statement of many of the objections raised by the DOE to full scrubbing, written by an active participant in the rulemaking, see Badger, supra note 7 . 
level "discovery" of a new face-saving solution to the NSPS problem. ${ }^{308}$ Relying on sketchy cost data provided by its Office of Research and Development, the EPA began to promote a new technology called the "dry scrubber." 309 The dry scrubber had a huge regulatory implication. Preliminary research indicated that dry scrubbing could operate more cheaply than old-fashioned wet scrubbing if it were not required to eliminate more than seventy percent of a coal's sulfur content. ${ }^{370}$ The dry scrubber thus provided a symbolically satisfying way to justify partial scrubbing. Because a guiding theme of section 111 is technologyforcing, ${ }^{371}$ would it not be counterproductive to insist on ninety percent scrubbing and "preclude" a promising new technology?

The computers were rushed into action: how much would it save if coalburners could use dry scrubbers to reduce sulfur by seventy percent? To emphasize the environmental promise of the new technology, the proposed regulation would allow seventy percent scrubbing only on condition that a power plant would meet a low ceiling of 0.6 , rather than the 1.2 tolerated for ninety percent wet scrubbing. ${ }^{372}$ In this way, the bureaucratic forces for a low ceiling got half a loaf; and when the computer results came rolling in, they revealed that the costs of a dry scrubbing-wet scrubbing sliding scale were far lower than the standard full scrubbing option and almost as low as the 0.55 ceiling. Moreover, given the 0.6 emission limit tolerated for dry scrubbing, the new proposal also generated lower $\mathrm{SO}_{2}$ discharges than its full-scrubbing competitor. ${ }^{373}$

368. See An Alternative Standard Keyed to Wet and Dry Scrubber Technology (unsigned memorandum) (Apr. 16, 1979) (on file with Yale Law Journal).

369. A dry scrubber is very similar to a wet scrubber, but the chemical reaction in a dry scrubber produces a dry powder rather than a liquid as in a wet scrubber. See Dry $\mathrm{SO}_{2}$ Control at 1-2 (unsigned, undated memorandum) (supplied to authors in May 1978 by members of EPA Office of Research and Development) (on file with Yale Law Journal), reprinted in part in Memorandum from Walter C. Barber to the Files (May 24, 1979) (EPA Docket No. OAQPS-78-I, Item No. IV-E-21). Dry scrubbing processes are mechanically simpler than wet processes and should prove more reliable. They consume less water (an important consideration in the West), and should create fewer sludge-handling problems than wet scrubbers currently do. See id. at 14; An Alternative Standard Keyed to Wet and Dry Scrubber Technology, supra note 368, at 1 .

Formal mention of dry $\mathrm{SO}_{2}$ scrubbing had been made in the EPA's September proposal, and commenters advocated the use of dry scrubbing at the December 1978 hearings. See 45 Fed. Reg. 8216 (1980). Although there were a few signs of growing awareness of dry scrubbing by February 1979, our interviews indicate that serious high-level interest in the technology did not appear until April 1979.

370. See Dry $\mathrm{SO}_{2}$ Control, supra note 369, at 5-14.

371. See, e.g., S. REP. No. 1196, 91st Cong., 2d Sess. 417 (1970) (advocating frequent revision of NSPS to provide incentives for constant improvement of control technology).

372. See 44 Fed. Reg. 33,614 (1979) (codified in 40 C.F.R. $\$$ 60.43a(a)(2) (1979)).

373. The EPA estimated that a standard permitting $70 \%$ dry scrubbing would save 
With computer printouts like this, ${ }^{374}$ Costle could go to the White House with new confidence. Not surprisingly, resistance within the Executive Office quickly faded. After all, it is embarrassing for the White House staff to urge the President to overrule a Cabinet-level officer on a subject within his agency's jurisdiction. Now that Costle had moved away from full scrubbing toward RARG, the White House staff had gained a sufficient victory. And so, when a meeting before the President was finally held in early May, only Energy Secretary Schlesinger announced his commitment to the RARG low ceiling option-and even he, from the reports we have received, was not outspoken.

Although the dry scrubber solved the Administrator's political problem, its relationship to sulfur removal is far more problematic. At present, there is no dry scrubber operating on a full-sized power plant anywhere in the United States. ${ }^{375}$ Some experts we have talked to liken present knowledge of dry scrubbing to the level of understanding of wet scrubbing prevailing in the early 1970s-when costs were thought to be only one half of what we now know them to be. ${ }^{376}$ Whether the dry scrubber will suffer a similar fate-indeed, whether it will work at all under field conditions-only time will tell.

We do not mean to condemn a high-level decision to reach deep within the innards of the EPA for intelligent guesses about the future. Instead, our point involves the kind of guesses high-level decisionmakers thought relevant to their policymaking predicament. If the EPA had been required to justify its decision in terms of environmental benefits, Administrator Costle would have had to call on agency modelers specializing in the long-distance transport of sulfates, rather than on agency experts in frontier technologies. Doubtless the models produced would have been imperfect, requiring innumerable guesses before the link between Midwestern smokestacks and Eastern ill health could be elucidated. Doubtless the coal companies and Senator Byrd would have attacked nonetheless. At least, though, we would have been arguing about the right questions and doing so in the open: How serious is the

almost $\$ 1.2$ billion a year by 1995 , while reducing nationwide emissions by 250,000 tons below the full-scrubbing $90 \%$ option. See ICF IV, supra note 298 , at 5 (using dry scrubbing cost estimates).

374. The modeling results actually shown White House aides seem to have differed slightly from those published later in more formal documents. See Memorandum from Walter C. Barber to the Files, supra note 369 (table 3) (discussing May 1, 1979 meeting).

375. See 44 Fed. Reg. 33,582 (1979). The nation's first three full-scale dry scrubbers were being installed in 1979 . See $i d$.

376. Compare 37 Fed. Reg. 5769 (1972) (estimated scrubber costs of $\$ 30$ or $\$ 45$ per kilowatt in 1978 dollars) with ICF III, supra note 298, at B-21 (estimated scrubber costs as high as \$90.113 per kilowatt). 
risk to human health? Are Eastern lakes being irreversibly damaged by acid rain? If we are to spend billions, should they be spent on new plants or old ones?

Although any answer to these questions is inevitably controversial, at least such a controversy would force policymakers to consider the consequences of their actions in the real world outside of Washington, D.G. By moving beyond the New Deal, we have moved away from a successful effort to understand the environment.

\section{Agency-Forcing Statutes and the Role of Courts}

At present, the EPA's NSPS decision is on appeal. ${ }^{377}$ Our case study supplies several guidelines for the court reviewing the Administrator's decision.

At the center of our story is a distinctive legal creature, which we have called the agency-forcing statute. Agency forcing provides a means for removing an issue from the general run of agency discretion, directing policy in a particular direction. At the same time, however, it signals a congressional recognition that, after all, the issue requires the exercise of expert judgment that cannot be applied directly from Capitol Hill. Thus, rather than setting down regulatory policy in explicit statutory terms, the agency-forcing statute contemplates careful policy reappraisal by the agency before the congressional initiative gains the force of law. Our present task is to define a role for courts that permits judges to check the worst abuses generated by agency forcing without pretending to a policymaking competence that outstrips judicial capacities.

\section{A. The Principle of Full Inquiry}

To begin, reflect upon an obvious danger generated by agency forcing. Simply put, it is the old Alphonse-Gaston problem: one player, Congress, enacts an agency-forcing statute with the expectation that the other will subject a particular policy to hard-headed consideration. The other player, the agency, thinks that Congress has already made the policy judgment and confines its policy review within narrow bounds. As a consequence, each player allows the other to drop the ball: an important policy is adopted without the hard thinking that should be required of a sound law-making enterprise.

To avoid such breakdowns, the court must adapt a classic function

377. See Sierra Club v. Costle, No. 79-1565 (D.C. Cir., filed June 11, 1979). The EPA denied requests for reconsideration of the standards in February 1980. See 45 Fed. Reg. 8210 (1980). 
of judicial review to the agency-forcing context. Traditionally, courts have been alert to the importance of scrutinizing administrative procedures to assure the full airing of policy options before agency decision. Given agency-forcing statutes, however, this focus on agency procedures-although still important-is no longer sufficient. The classic judicial concern with a full policy airing must also inform the court's approach to problems that arise in the interpretation of the agencyforcing statutes themselves. Agency-forcing statutes should be read in the light of the principle of full inquiry-requiring the fullest possible agency inquiry into competing policy approaches consistent with the text of the agency-forcing statute..$^{378}$

To make this principle more precise, distinguish several kinds of statutory interventions within the agency-forcing category. The first, and most modest, statute simply forces the agency to focus decisionmaking attention on a particular question, the desirability of scrubbing for example, rather than the countless other policy questions that might have occupied its time. ${ }^{379}$ In contrast to this agenda-forcing function, more aggressive statutes aim to give a particular policy solution special salience in the agency's deliberations-call this solution forcing. Vocabulary taken from the law of evidence can help analyze these more aggressive efforts. The most modest statute might simply allocate the burden of coming forward ${ }^{380}$ without affecting the ultimate burden of persuasion. For example, Congress might instruct the EPA to select the full-scrubbing option if it could not generate a credible technocratic analysis to inform its deliberations. More active legislative involvement comes through shifting the burden of persuasion. ${ }^{381}$ The agency might be instructed to accept full scrubbing unless it is per-

378. Cf. Blumrosen, Toward Effective Administration of New Regulatory Statutes, 29 Ap. L. REv. 87, 89-100 (1977) (agency administrators should be required to construe reform legislation broadly).

379. Many of the Clean Air Act's sections carrying statutory deadlines fall into this category. See, e.g., 42 U.S.C. $\$ 7409$ (d)(1) (Supp. II 1978) (duty to review NAAQS at least once every 5 years); $i d . \$ 7411(\mathrm{~b})(1)(\mathrm{B})$ (duty to review NSPS); $i d$. $\$ 7422$ (duty to review health effects of certain unregulated pollutants); $i d . \$ 7408(\mathrm{c})$ (duty to review air quality criteria and revise criteria for $\mathrm{NO}_{2}$ ).

380. See, e.g., 15 U.S.C. $\$ 78 \mathrm{~g}(\mathrm{a})$-(b) (1976) (Federal Reserve Board may set margin requirements for securities purchases lower or higher than congressional standard if appropriate in light of general credit situation).

381. See, e.5., 29 U.S.C. $\$ 655$ (a) (1976) (requiring Secretary of Labor to promulgate "national consensus standard" or "established Federal standard" as occupational safety or health standard "unless he determines that the promulgation of such a standard would not result in improved safety or health for specifically designated employees"); 15 U.S.C. $\$ 2605$ (e) (1976) (Administrator shall ban polychlorinated biphenyl if not totally enclosed, unless he finds that use will not present unreasonable risk of injury to health or environment). 
suaded that the policy is unwise. Finally, the agency-forcing statute may alter the burden of proof. It may specify that the EPA shall impose scrubbing unless the agency is convinced beyond all reasonable doubt that scrubbing is unwise. 382

Although these distinctions are familiar, they have not customarily been invoked in the interpretation of agency-forcing statutes-not least because the distinctive character of these statutes has been insufficiently appreciated. Yet, having imported these familiar concepts into a new area, it is possible to define the principle of full inquiry in judicially manageable terms. In a nutshell, courts should not be quick to read the more aggressive forms of agency forcing into ambiguous statutory language. A congressional instruction that may be read simply as an exercise in agenda forcing should not be escalated into a form of solution forcing. A statute that may be read as allocating the burden of coming forward should not be blown up into a congressional judgment about the burden of persuasion. And so forth. Easy escalation runs the risk of an Alphonse-Gaston mistake. In contrast, the risk of error involved in an interpretive policy of deescalation is far smaller. Suppose, for example, that Congress "really" intended to shift the burden of proof on scrubbing while the courts interpret the statute to require only agenda forcing. If, in response, the Administrator finds scrubbing a wrongheaded policy, this will merely force Congress to focus more seriously than it might otherwise on the hard facts that lie beneath the pretty symbols. ${ }^{383}$

A similar perception lies at the core of Judge Leventhal's landmark decision in International Harvester Co.v. Ruckelshauss. ${ }^{384}$ Congress had ordered the automakers to reduce automobile emissions by 1975 , but allowed the Administrator to defer this legislative solution by one year if the carmakers satisfied four stringent criteria. ${ }^{385}$ The Administrator denied the companies' request for a deferral, relying on a restrictive

382. Cf. 42 U.S.C. $§ 7409$ (c) (Supp. II 1978) (requiring promulgation of three-hour standard for nitrogen oxide unless the administrator finds "no significant evidence that such a standard for such a period is requisite to protect public health").

383. The House has approved of the use of full inquiry to promote fuller use of agency expertise. See H.R. REP. No. 1013, 93d Cong., 2d Sess., reprinted in [1974] U.S. CODE ConG. \& AD. News 3281, 3292 (voicing House approval of Judge Leventhal's intervention in International Harvester Co. v. Ruckelshaus, 478 F.2d 615 (D.C. Cir. 1973)).

384. 478 F.2d 615 (D.C. Cir. 1973); see South Terminal Corp. v. EPA, 504 F.2d 646, 665. 67 (1st Cir. 1974) (setting aside EPA-promulgated transportation control plan for Boston area due to insufficient justification of standards).

385. Clean Air Amendments of 1970, Pub. L. No. 91-604, sec. 6(a), \$ 202(b)(5)(D)(i)-(iv), 84 Stat. 1676 (current version at 42 U.S.C. $\$ 7521$ (b)(5)(C)(i)-(iv) (Supp. II 1978)) (setting forth criteria). 
view of the range of inquiry that the statute permitted him. ${ }^{386}$ This was unacceptable to Judge Leventhal, who detected the risk that a decision with serious impact on the nation's economy was being generated by an Alphonse-Gaston process. Rather than run this risk, Leventhal interpreted the statute as requiring a broader administrative inquiry. ${ }^{387}$ The principle of full inquiry develops Leventhal's insight into the risks of agency forcing into a more general guideline-preventing the agency from arbitrarily constricting the range of policy choices left open by the statutory text.

In the present case, the principle of full inquiry requires a strong remand to the EPA for further consideration. Rather than interpreting section 111 as an agenda-forcing provision, the EPA read it as a strong form of solution forcing. The agency only considered whether some plants should be permitted to scrub less than others; it completely failed to consider whether it would be both cheaper and environmentally sounder to permit plants to dispense with scrubbing entirely and meet the NSPS by burning low sulfur coal.

Yet, as we have shown, a reading of the statutory text hardly required this narrow focus. Not only is the Administrator explicitly required to consider costs, but the statutory text gives no indication of a solutionforcing intention. ${ }^{388}$ The new amendment to section 111 merely changes the form of EPA regulation, requiring the agency to set percentage treatment requirements for coal burning. Although this new formal requirement certainly counts as agenda forcing, it violates the principle of full inquiry to permit the agency to promote it into the strongest form of solution forcing by excluding low sulfur coal, without analysis, from the range of policy options.

\section{B. The Principle of Textual Priority}

At this point, the court will confront a characteristic difficulty. The partisans of the policies behind the agency-forcing statute will try, as best they can, to inflate the proportions of their legislative victory. Rather than directing agency attention in a particular direction, they naturally wish to portray the decision as if it had been completely resolved by Congress. Moreover, given the extremely weak controls imposed on the content of committee reports, they will often be in a position to make legislative history for themselves in ways that move far

386. See International Harvester Co. v. Ruckelshaus, 478 F.2d 615, 624 (D.C. Cir. I973).

387. See id. at $633-41$.

388. See pp. 1508-10 supra. 
beyond a minimalist interpretation of the statutory language. ${ }^{389}$ How should courts view such committee room triumphs?

They should ignore the committee report and read the text of the statute in the minimalist fashion prescribed by the principle of full inquiry. It is only by insisting on explicit statutory language that courts can assure themselves that the committee report represents more than a successful effort by a handful of insiders to exploit the overloaded congressional docket. ${ }^{390}$ The regular application of this principle of textual priority will, over time, bring home to the staff and lobbyists on Capitol Hill that there is only one way to force an agency to do their bidding-and that is to engage in the full debate traditionally associated with explicit statutory amendment. Textual priority is especially im. portant in the interpretation of a large and complex statute like the Clean Air Act. Such statutes have their own distinctive architecturewith a few basic principles motivating the often intricate ground plan. Although particular agency-forcing provisions may sometimes explicitly require regulators to depart from basic statutory purposes, courts should not destroy the statutory ground plan on the basis of subterranean legislative history.

The present case provides a textbook example of the dangers to democratic principle that flow from the abuse of legislative history. In 1977 , the clean air-dirty coal lobby would have vastly preferred a single statutory phrase commanding full scrubbing to a ream of legislative history in praise of "locally available" coal. The reason the lobby settled for less is that it feared it would lose if it went for broke. Moreover, such fears seem perfectly rational when the 45 to 44 Senate victory of section 125 is recalled. Here was a section that explicitly authorized the use of scrubbing for the protection of Eastern coal; yet, although it was hedged about with all sorts of checks, it gained the narrowest of victories. This fact speaks louder than ten thousand words of legislative history. If it was so hard to gain the largely symbolic relief for Eastern coal promised by section 125 , why should a court presume that Congress "intends" the expenditure of tens of billions of dollars when this intention has not yet achieved clear expression in the text of section 111 ?

389. Although we do not wish to approve the mechanistic approach to textual analysis recently favored by the District of Columbia Circuit in Alabama Power Co. v. Costle, 606 F.2d 1068 (D.C. Cir. 1979), the decision does represent a turn away from casual reliance on low-level legislative history; to that extent, it does support the principle presented here.

390 . In the words of Justice Frankfurter, "[l] oose judicial reading makes for loose legislative writing." Frankfurter, supra note 116, at 545 . 
To endow our point with the dignity of a platitude: the basic purpose of the Clean Air Act is to clean the air.301 Reading the "new" section 111 as an agenda-forcing statute will serve this basic purpose, encouraging EPA to invest more of its resources in sensitive long-range planning. Reading section 111 as if it were a solution-forcing statute will, in contrast, subvert the basic purpose of the Act. Instead of cleaning the air, such a reading requires the Administrator to bail out the producers of polluting products. When confronted with a clear affirmation of this policy, as in section 125, both agencies and courts may have no choice but to give way. In the absence of a clear statutory text, however, neither agency nor court should read section 111 as encouraging a massive bailout for sectional interests.

\section{The Coordination Principle}

Agency forcing not only raises distinctive problems of congressionaladministrative coordination but also places special pressures on the executive branch. Forcing an issue onto one agency's agenda will predictably generate ripple effects as other agencies respond to the agency forced into action. These responses, in turn, impose pressures on the White House to help shape the congressional initiative into a policy that gives due regard to the missions of other agencies that may be sacrificed by too narrow an inquiry. As a consequence, an agency may find itself awkwardly placed between a congressional directive, on the one hand, and an executive mandate, on the other.

Such contretemps can obviously raise constitutional issues. ${ }^{302}$ Yet before a court forces a confrontation to this level, it first should search for a plausible statutory interpretation that renders it unnecessary. This search may prove especially rewarding in the agency-forcing context. After all, in refraining from specifying a final solution, Congress itself has recognized the need for further agency study. And if agency analysis reveals a sharp conflict with the goals of other agencies-goals that Congress has also recognized in other statutes-courts should not be quick to say that the agency-forcing statute forbids policymakers to take these competing goals into account. Otherwise, a narrowly focused statutory directive may undermine policies that Congress might well have valued more highly if it had fully appreciated the effect of its agency-forcing mandate. This principle of coordination is particu-

391. See 42 U.S.C. $\$ 7401$ (b)(1) (Supp. II 1978).

392. See generally Bruff, Presidential Power and Administrative Rulemaking, 88 YaLE L.J. 451, 498-508 (1979). 
larly appropriate when reading statutes, like the Clean Air Act, that explicitly require interagency cooperation..$^{393}$

From this point of view, the present case permits an especially easy application of the principle of coordination. On some occasions this principle might suggest that a court require an agency to undertake the bureaucratically difficult task of considering a legislative goal far removed from its ordinary mission. In the present case, however, this was not the nub of the White House's complaint about EPA conduct. Instead, the RARG report focused upon the agency's failure to bring to bear its environmental expertise upon the problem at hand. In essence, RARG was saying that before the EPA imposed a multibillion dollar burden on the congressionally approved goal of energy independence, it should, at the very least, show how this would yield a better environment. ${ }^{394}$ Rather than deploying its expertise to coordinate policy in this minimal way, the EPA responded by reading section 111 in a way that made environmental sophistication unnecessary. Although this reading is untenable under the first two principles of statutory interpretation, the court should look upon the RARG report as an indication that the EPA's question-begging analysis generated real problems of coordination in the executive branch; and that, when the issue returns to the agency, it should make a good faith effort to discharge its statutory obligation to take costs "into consideration" in the only sensible way-by trying to define the net costs of the scrubber when it is compared to alternative ways of achieving the same environmental objectives. More particularly, the court should encourage the EPA to make use of its latent expertise and consider the possibility that there are cheaper, quicker, and more certain ways of responding to the only environmental problem that would remotely justify forced scrubbing-the risks that sulfates, not sulfur dioxides, pose to Eastern health and ecology as well as to Western visibility.

393. 42 U.S.C. $\$ 7417$ (c) (Supp. II 1978).

394. Cf. Portland Cement Ass'n v. Ruckelshaus, 486 F.2d 375, 387 (D.C. Cir. 1973), cert. denied, 417 U.S. 921 (1974) (EPA should consider cost-benefit studies submitted to it); Kennecott Copper Corp. v. EPA, 462 F.2d 846, 850 (D.C. Cir. 1972) (requirement that EPA supply sufficiently detailed explanation of basis of promulgated standard for court to review). The agency, in its promulgation, offered no response even to the crude exposure index developed by RARG. See 44 Fed. Reg. 33,602-08 (1979). We do not mean to suggest that the EPA pretend to a clear understanding of pollutant effects where only uncertainty exists. It seems clear, though, that even given current limits to scientific knowledge, the EPA could offer a far more coherent explanation of what it hopes to accomplish with the new NSPS than it has to date. Such an explanation would presumably begin by focusing on desired health and ecological effects, not meaningless comparisons of nationwide emissions of $\mathrm{SO}_{2}$. See $\mathrm{pp}$. 1515-36 supra. 


\section{Beyond Formalistic Review}

Our case study suggests an additional ground for judicial intervention. Although the agency responded to the evolving controversy in creative procedural ways, it could have imposed even more stringent formalisms on the process we have described. For one thing, the heavy reliance on dry scrubbing was hardly anticipatable from a careful reading of the September notice of proposed rulemaking. Perhaps, then, the EPA should be required to reissue a new proposal and go through another round of comment? Similarly, the agency's treatment of a host of "outsiders," ranging in substantive views from Senator Byrd to Secretary Andrus, might be challenged and any number of new formalisms proposed. ${ }^{395}$ We believe, however, that the judges should resist these familiar temptations. Although some minimal procedural forms are necessary to assure fairness, their proliferation will have very unfortunate consequences.

To glimpse the first danger, consider the relative innocence with which the EPA viewed the scrubbing problem at the time it filed its September notice in the Federal Register. At that point, the agency had only begun to redeem a decade's neglect. While the computers were humming, the results had not yet been assimilated. Now imagine that Administrator Costle had known, in September, that he would be obliged to go through yet another round of notice-and-comment rulemaking if the September-January round actually generated some new insights and proposals. Would he have authorized the Planning Office to proceed with its modeling activity? After all, there is always one way to assure that nothing new will come out of a rulemaking proceeding, and that is to refuse to invest analytic resources in the learning process. Agency learning should not be penalized when it actually uncovers something new. There are enough temptations to ignore economic and ecological realities without the law making learning costly.

Yet the threat to agency learning is only one half of the price of undue formalism. Paradoxically, formalism will also endanger the very values of fair notice and effective participation it seeks to assure. At present, EPA officials often meet with outsiders at both technical and policymaking levels, getting new ideas and informally gauging response

395. Participants in the rulemaking have argued that Senator Byrd's meeting with agency officials was improper both because it constituted a prohibited ex parte contact, see Home Box Office, Inc. v. FCC, 567 F.2d 9, 57 (D.C. Cir.), cert. denied, 405 U.S. 1030 (1972), and because it allowed the Senator to influence the rulemaking by use of political pressure, see D.C. Fed'n of Civic Ass'ns v. Volpe, 459 F.2d 1231, 1245-46 (D.C. Cir. 1972) (invalidating administrator's decision based partially on political pressure). For the EPA's response to these arguments, see 45 Fed. Reg. 8214-15 (1980). 
to possible regulatory initiatives. A formalistic approach to "outside intervention" would jeopardize this rich set of informal contacts, destroying a vital supplement to the inevitably inadequate publications in the Federal Register. The National Coal Association, for example, was able to intervene effectively in the NSPS decision because of the informal notice-and-comment mechanism evolving at the EPA. Rather than hiding behind the formal closing of the comment period and refusing to discuss the impacts of its chosen standard on an important industry, the EPA allowed the NCA, in the presence of its opponents, to advance its coal preclusion argument. An agency that responds in this creative fashion should not be subject to Monday morning quarterbacking from the bench.

We take a similar view of even the most dramatic forms of "outside intervention" revealed by our case study. Although we believe it was wrong for the agency to cave in to Senator Byrd, this is not because a few officials actually spoke to the Senator in the White House. A similar meeting, after all, could have been arranged by inviting EPA staff to testify before the Senate Committee on Environment and Public Works, which is chaired by the other Senator from West Virginia. $^{396}$ In any event, the Administrator would undoubtedly know the opinion of the Senate majority leader on an issue of such importance to his home state.

Moreover, so long as one concedes the relevance of the legislative history, Senator Byrd had a good point: was the EPA, in proposing a low ceiling, doing all it could in the name of "locally available" coal? If the question is legally relevant, we can think of nobody more appropriate to raise it than the Senator from West Virginia. ${ }^{307}$ Because the Senator's meetings were entered in the docket, everyone had notice of their existence. ${ }^{398}$

396. In fact, Congressmen questioned EPA officials, sometimes quite sharply, on several accasions about NSPS during hearings held while the rulemaking studied here was still in progress. See, e.g., Executive Branch Review of Environmental Regulations: Hearings Before the Subcomm. on Environmental Pollution of the Senate Comm. on Environment and Public Works, 96th Cong., Ist Sess. 252-53 (1979) (statement of Douglas Costle) (answering question critical of protecting Eastern coal); Cost of Government Regulations to the Consumer: Hearings Before the Subcomm. for the Consumer of the Senate Comm. on Commerce, Science, and Transportation, 95th Cong., 2d Sess. 323.26 (1978) (statement of Walter C. Barber) (answering questions critical of sludge produced by scrubbers).

Courts have traditionally been reluctant to reverse administrative decisions on the basis of exchanges between administrative officials and Congressmen in their official capacities. See, e.g., American Pub. Gas Ass'n v. Federal Power Comm'n, 567 F.2d 1016, 1067-69 (D.C. Cir. 1977), cert. denied, 435 U.S. 907 (1978); Gulf Oil Corp. v. Federal Power Comm'n, 563 F.2d 588, 610-11 (3d Cir. 1977), cert. denied, 434 U.S. 1062 (1978). But see Pillsbury Co. v. FTC, 354 F.2d 952 (5th Cir. 1966).

397. Except perhaps the Senators from Ohio.

398. The EPA contended both before and after the meeting with Senator Byrd that 
The problem with Byrd's intervention was not procedural but substantive. It was simply another battle in the war begun by the clean air-dirty coal lobby in 1976 to escalate its carefully drafted legislative history into law. The agency was wrong to give it heed for the same reason it was wrong to allow the committee report rhetoric to narrow its scrubbing inquiry. The capitulation to a powerful Senator only dramatizes the danger of moving beyond the text of an agency-forcing statute. ${ }^{399}$

The court's main concern should not be with the NGA presentation or the Senator's protest but with the EPA's narrow conception of its mission. Section 111 did not force a solution on the EPA. It only required that the agency give the scrubber high priority on its decisionmaking agenda. Congress intended the agency to use its expertise to determine whether the scrubber made environmental sense given its costs. The agency's last minute capitulation to Senator Byrd was only a symptom of its larger failing to discharge its planning functions. It was not incorrect for the Administrator to speak with members of the body that supervised his exercises in policymaking. Criticism is properly due the agency for failing to relate its scrubbing decision to what the Act plainly requires: cleaning the air in a cost-effective way that yields real environmental benefits.

We should be clear about what we have not been saying. At no point have we suggested that the courts should take primary responsibility for the development of substantive policy under the Act. Instead, the objective of judicial review remains as it was under the classical New Deal conception-to assure a full and focused airing of plausible policy options before officials make decisions of consequence. ${ }^{400}$ The move beyond the New Deal agency requires, however, that courts delicately calibrate Congress-agency relationships to prevent mindless decisionmaking. Careful employment of the three maxims of full inquiry,

its actions were designed to be consistent with Home Box Office, Inc. v. FCC, 567 F.2d 9, 57 (D.C. Cir. 1977), cert. denied, 434 U.S. 829 (1977). See Executive Branch Review of Environmental Regulations: Hearings Before the Subcomm. on Environmental Pollution of the Senate Comm. on Environment and Public Works, supra note 396, at 242 (statement of Douglas Costle); 45 Fed. Reg. 8214-15 (1980) (denying petitions for reconsideration). The fact that the EPA recorded a significant number of ex parte contacts in the rulemaking docket tends to support this assertion.

399. It is also rumored that Senator Byrd threatened to vote against the SALT II treaty if the EPA did not retreat to a 1.2 ceiling. We have found no hard evidence to support this rumor and our analysis makes it unnecessary for the court of appeals to give it any weight. Even if Byrd did not make this threat and restricted himself to arguments on behalf of Eastern coal, the agency was wrong to give way before him. Until Eastern coal succeeds in revising the statutory text, its interests are not entitled to special prominence in the Administrator's comprehensive analysis of the costs of the NSPS decision.

400. Cf. Kennecott Copper Corp. v. EPA, 462 F.2d 846, 850 (D.C. Cir. 1972) (requiring sufficiently reasoned explanation of basis of standards for informed judicial review). 
textual priority, and coordination will avoid needless and costly disappointments resulting from the effort to venture beyond New Deal ideals.

Applied to the present case, these principles suggest a strong remand to the Administrator. On reconsideration, he should not take the asserted threat to Eastern coal as a reason for requiring scrubbing. Nor should he ignore RARG's insistence that before the agency imposes the multibillion-dollar cost of scrubbing on the American people, it should point to environmental benefits that remotely justify the burden.

\section{Ends and Means in Administrative Law}

The ultimate question raised by our case study is the wisdom of the Clean Air Act's effort to move beyond the New Deal ideal. The story we have told serves as an ironic tribute to discarded New Deal virtues. The Act discarded the idea that policymaking should be insulated from direct congressional intervention. But instead of providing a solution responsive to the evolving will of a national majority, congressional intervention mixed clean air symbols and dirty coal self-interest in a way that invites cynicism about democratic self-government. The Act rejected the idea that responsible policymaking required a careful sifting of the facts so that regulatory means will be carefully crafted to achieve desired ends. Yet the legislative affirmation of technology forcing only raises doubts about technology's ability to answer our ecological predicament.

The Clean Air Amendments of 1970 went wrong not in their basic diagnosis, but in the particular cure prescribed for the disease. In 1970 , the country was ready for an aggressive effort to reduce pollution. Environmentalists correctly saw the need to ensure that administrative inaction did not sabotage this effort. The innovative idea of agency forcing responded to this need.

Agency forcing can proceed in two ways, however, and it was in this choice that the congressional cure turned on itself. In "means-oriented" agency forcing, Congress takes the agency by the hand and tells it precisely which regulatory means to use to reach stated policy objectives. The congressional approach toward new coalburners, which gave undeserved prominence to high-technology solutions, reflects this means-oriented approach. Under the contrasting form of agency forcing, Congress requires the agency to define its ends aggressively and to take those steps that promise to reach those goals effectively. This approach 
was taken by sections 108 and 109 of the Act, ${ }^{401}$ requiring the Administrator to establish ambient air quality standards "to protect the public health" and establishing 1977 as the date by which the United States was to reach these initial clean air objectives. Unlike its competitor, "ends-oriented" agency forcing does not require Congress to indulge in instrumental judgments of a kind far beyond its capacity. Instead, ends forcing generates a process that clarifies the ultimate aims of environmental policy.

Consider, for example, the way in which Congress' ends-oriented exercise of 1970 was rewarded in 1977 by increased sophistication in the specification of environmental aims. By 1977 the Administrator's efforts to specify air quality objectives and to prod the states into speedy compliance had generated some simple, but important, lessons. First, the original congressional effort to specify objectives had failed to consider the peculiar values at stake in the clean air regions. Thus, 1977 became an occasion for clarifying new objectives for environmental policy. Second, reaching the old objectives turned out to be far more costly and difficult than imagined. Thus, 1977 became a time for reappraising old objectives and deciding how forcefully to pursue them in the future. The legislative history reveals the seriousness with which Congress considered the global trade-offs involved in these problems of ends specification. ${ }^{402}$

Contrast this success with the sorry effort in 1977 to engage in means forcing-which permitted the dirty coal lobby to exploit the technical incompetence of Congress to further ends peripheral to the main goals of environmental law. Although there is no undoing the past, surely we can hope in the future to come to terms with the complexity of agency forcing-building upon the ends-oriented achievements of the past while trying to ameliorate the harms generated by the meansoriented approach. From an ecological point of view, a pound of pollution is a pound of pollution, regardless of the age of the polluter. Meansoriented agency forcing should not be allowed to generate a nevernever world where this basic ecological fact is obscured from view. A long-term strategy for new plants must be combined with a short-term strategy allowing polluters to trade off costly technology in new plants against cutbacks in pollution coming from old plants. Although this

401. 42 U.S.C. $\$ \$ 7408.7409$ (Supp. II 1978).

402. See, e.g., Senate Hearings-1977 Amendments, supra note 130, at vi-xxi (1977) (summary of testimony prepared by Congressional Research Service); 1977 House Hearings, supra note 95, at 240-62 (statement of Carl M. Shy, American Lung Association) (focusing on health effects of various pollutants); $i d$. at 1250-1329 (statements of representatives of numerous industry organizations focusing largely on question of Act's proper ends). 
"offset" principle has already gained some statutory recognition, ${ }^{403}$ courts should support the EPA efforts to make offsets operational and to broaden their application to new plants. ${ }^{404}$ By emphasizing the tradeoff between old and new plants, the EPA will save money while educating Congress to the hazards of means-oriented agency forcing.

In addition, Congress must build upon its genuinely valuable exercises in ends-oriented agency forcing. We must learn to look with a critical eye upon instructions, like that found in section 109, to set ambient air standards in a way that "protect[s] the public health" while "allowing an adequate margin of safety ...." Such vague formulae represent the unhappy legacy of a New Deal past that too readily delegated basic value choices to bureaucratic "experts." Rather than speaking vaguely of the "public health," the task is to define clear and operational goals through the democratic process and then challenge the experts to meet these goals in a fair and efficient fashion by a date certain. ${ }^{405}$

Imagine, for example, an amendment that required the Administrator to "achieve ambient air quality improvements that promise to add at least 25,000 years to the life expectancies of the American people by 1984." Such a statute would have forced agency action of a kind very different from the sort described in our case study. To begin, the statute would have forced agency policymakers to ask themselves which of countless possible regulatory initiatives could

403. Section 173 of the Act allows continued economic growth in areas that have not attained clean air targets by allowing the construction of a new plant on the condition that the plant obtain offsetting emission reductions from existing plants in the area. 42 U.S.C. $\$ 7503(1)$ (A) (Supp. II 1978).

404. Most recently the Court of Appeals for the District of Columbia Circuit sustained the EPA's decision to allow offsets between different facilities within the same plant as part of the agency's "bubble" concept. See Alabama Power Co. v. Costle, 606 F.2d 1068 (D.C. Cir. 1979).

Prior to Alabama Power Co., a majority of a panel of the same circuit concluded that the EPA had the authority to authorize offsets between facilities of the same plant, even though it had not used that authority properly in the case before it. ASARCO, Inc. v. EPA, 578 F.2d 319, 330-31 (D.C. Cir. 1978) (Leventhal, J., concurring, and MacKinnon, J., dissenting). Judge Leventhal's opinion in $A S A R C O$ is an instructive example of the agency-forcing principles outlined above. Judge I.eventhal's approach first required the Administrator to use the agency's expertise to identify situations in which innovative plans like an offset policy would further underlying statutory goals, such as reducing emissions from modified sources in a way that best took costs into account. In ASARCO itself, Judge Leventhal found that the EPA had not made a full enough inquiry into the merits of an offset policy to justify its use. See id. at 331. Importantly, however, Judge Leventhal found textual authority, under $\S 111(\mathrm{~b})(2)$, for the use of offsets between facilities of the same plant if sufficient study occurs, and thus offered the possibility of more far-reaching innovations.

405. Although their particular proposals are different, the need for more operational targets in the Clean Air Act is also emphasized by J. KRIER \& E. URSIN, Pollution AND PoLICY 327-45 (1977). 
plausibly be related to the " 25,000 life-year" goal. As soon as the matter was framed in this way, decisionmakers would become acutely aware of the state of our ignorance about the health effects of air pollution. Yet the fact that the statute would require the agency to engage in highvisibility guesswork is not an argument against ends-oriented agency forcing. To the contrary, this is its greatest institutional strength for two reasons. First, with the need for guessing on the table, it may no longer be so embarrassing to admit that some guesses have turned out wrong. To take an example from our case study, it is now conventional wisdom within the agency staff that $\mathrm{SO}_{4}$, not $\mathrm{SO}_{2}$, should be the sulfur oxide of primary concern. Nonetheless, thanks to the freezing of hard variables, it is not clear when-if ever-this recognition will be fully reflected in the ambient standards that purportedly protect "the public health." In contrast, new bureaucratic incentives would emerge under the 25,000-years approach. Here, if there were reason to argue that $\mathrm{SO}_{4}$ control would help the agency present Congress a better progress report in 1984, there would be increased incentives to overcome agency inertia, change the pollution target, and design a program that may be credibly related to the " 25,000 year" target.

Second, high-visibility guesswork would require high policymakers to take the question of research priorities far more seriously than they do at present. Whatever may be said about the "myth" of administrative expertise in other areas, the EPA today has the capacity to launch an enormously useful research enterprise. And there is no better way to interest policymakers in the direction of research policy than by linking their reputations to the data that are gathered and analyzed.

Not that ends-oriented agency forcing is offered as a panacea. The present state of model building, even data monitoring, permits a wide range for agency discretion. And agencies will use this discretion in ways that will generate good report cards when the time comes for congressional oversight. Thus, it is a good bet that if the "25,000 year" goal had been announced in 1977, the EPA would have found a way to have its computers declare that its policies had saved far more than "25,000 years" in 1984. Nonetheless, our case study suggests that it is better to give an optimistic answer to the right question-what is happening to the air?-than to engage in a desperate attempt to answer the wrong question-how well do scrubbers work?

Although ends forcing promises, over time, to improve the quality of EPA decisionmaking, perhaps its most important contribution will be to the quality of future congressional deliberation. If the Congress of 1977 had set the "25,000 year" target, the debate of 1984 would have 
naturally focused upon the ends that had been specified. Agency selfinterest would have motivated an EPA demand for expanded operational goals, framed, in keeping with the ends-forcing orientation, in terms of physical discomfort and aesthetic affront. In contrast, groups representing energy users would have banded together to weaken the goals. Rather than inviting bizarre coalitions between clean air and dirty coal, the focus on operational goals would have invited a democratic test of opinion between pro- and anti-environmental forces. ${ }^{400}$

Once again, we do not want to paint too rosy a picture. Doubtless the Senate of 1984 will contain two advocates of the West Virginia coal mines. Doubtless they will try to exact an "understanding" about scrubbing as a condition for aiding the campaign for a "pro-environmental" specification of EPA ends. Nonetheless, a shift in the form of agency forcing would focus congressional debate on the issues Congress is most competent to handle. Rather than indulging in a hurried pseudo-technocratic judgment about the scrubber, Congress would focus on fundamental issues. Are we doing too much or too little in the way of environmental protection? What real world interests-in terms of health and other amenities-should be emphasized? How well is the EPA really doing in meeting its operational goals and setting new objectives that seem sensible?

It is not enough, however, for Congress to monitor agency performance at regular intervals and set operational goals for the next septennium. Beyond the next decade, there is the next generation. And our case study gives eloquent testimony to the ease with which longrange planning can be sacrificed to meet the middle-range goals set by Congress. To discharge a minimal obligation to the future, we must assure that they will have a better understanding of the world we have bequeathed them. In pursuit of this end, Congress must massively increase funds for monitoring and modeling the environment. And at every septennial review, a special branch of the EPA charged with long-run planning should be invited to focus attention upon the most salient policy redirections suggested by the direction of scientific research. ${ }^{407}$ In terms of our present case study, what seems most urgent

406. Moreover, once environmental advocates in Congress began specifying their goals in operational terms, it is possible that their opponents would respond by specifying their goals in a like fashion. Thus, instead of a simple requirement to save 25,000 life-years, our hypothetical statute might read "save 25,000 life-years in 1984 by requiring polluters to spend no more than $\$ 25$ billion a year in air pollution control costs." See generally Regulatory Budgeting and the Need for Cost-Effectiveness in the Regulatory Process: Hearings Before the Joint Economic Comm., 96th Cong., 1st Sess. (1979).

407. Congress in 1977 established a National Commission on Air Quality to advise it 
now is a redefinition of the sulfur oxide problem so as to emphasize sulfates, rather than sulfur dioxides, and the organization of a set of regional institutions capable of handling the problem of long-range transport. But it is always possible that ten years more of research will make this now-conventional wisdom as dated as the EPA's fixation on SO.2 seems today. What is required is a branch of the EPA that does not see obsolescence as a bureaucratic threat but as a source of institutional power.

Once again, it is more important that this planning branch force decisionmakers to ask the right questions than to guarantee the "right" answers. For there are no "right" answers to the ultimate questions of environmental policy-only questions that breed more questions.

We do not mean to be too harsh in our judgment of the congressional draftsmen of 1970 or 1977. Even today, the hard work required to design a workable form of ends-oriented agency forcing is yet to be done. Encouraging signs can be seen, however, in Congress, ${ }^{408}$ the Executive, ${ }^{409}$ and academia. ${ }^{410}$ Given its experience with New Deal agencies, Congress was sensible to try to force aggressive agency action with the crude tools at its disposal. Like our predecessors, however, we too should try to learn from our mistakes and hope that our future blunders will be as fruitful as theirs were.

before the Act returns for revision. Clean Air Act Amendments of 1977, $\$$ 313, 42 U.S.C. $\S 7623$ (Supp. II 1978). As a result of the Ieisurely appointment of commissioners, the panel is off to a slow start, and it is too early to assess its work.

408. See, e.g., Regulatory Budgeting and the Need for Cost-Effectiveness in the Regulatory Process: Hearings Before the Joint Economic Comm., supra note 406; SEN. CoMM. ON Governmental Operations, supra note 28.

409. See, e.g., Regulatory Reform: Mfessage from the President, H.R. Doc. No. 80, 96 th Cong., 1st Sess. (1979).

410. See, e.g., Breyer, Analyzing Regulatory Failure: Mismatches, Less Restrictive Alternatives, and Reform, 92 HaRv. L. REv. 549 (1979); C. DeMuth, Regulatory Costs and the "Regulatory Budget" (Dec. 1979) (unpublished Faculty Project on Regulation, John F. Kennedy School of Government, Harvard University). For a small sampling of the many projects now in progress, see E. BARDACH \& R. KAGAN, ThE INSPEctorate (forthcoming, provisional title); R. Litan \& W. Nordhaus (forthcoming work on regulatory reform).

This concluding section is developed further in our book-length treatment, which speculates more broadly on the links between institutional frameworks and the structure of political coalitions. See our CLEAN AIr/DIRTY CoAL, chap. 8 (forthcoming, Yale University Press). 


\title{
The Yale Law Journal
}

Volume 89, Number 8, July 1980

\author{
John M. Campbell \\ Editor-in-Chief
}

\author{
Michael D. Klausner \\ Note \& Topics Editor
}

Vincent J. Chiarello

Perry Dane

Stuart A.C. Drake

John D. Echeverria

Note Editors
David E. Van Zandt

Managing Editor

Carol F. Lee

Dwight C. Smith III

Richard G. Taranto

Kenneth S. Taymor

Donald J. Toumey

Article \& Book Review Editors
Charles W. Fournier

Steven M. Kamp

Judith A. Lachman
Robert L. McGlasson

Rachel F. Moran
Russell G. Pearce

Patrick W. Shea

Jeffrey W. Stempel

Assistants to the Editors Edna I. Scott, Pamela Willmott

\section{Student Contributors to This Issue}

Vincent J. Chiarello, The Accounting Provisions of the Foreign Corrupt Practices Act: An Alternative Perspective on SEC Intervention in Corporate Governance

Stuart A.C. Drake, Judicial Resolution of Inter-Agency Legal Disputes

Richard G. Taranto, A Process-Oriented Approach to the Contract Clause 